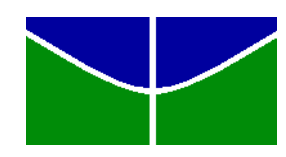

UNIVERSIDADE DE BRASÍLIA - UNB

FACULDADE UNB DE PLANALTINA - FUP

PROGRAMA DE PÓS-GRADUAÇÃO EM GESTÃO PÚBLICA - PPGP

JULIANA TEIXEIRA DOS ANJOS

PLANO DE GERENCIAMENTO INTEGRADO DE RESÍDUOS SÓLIDOS PARA UMA INSTITUIÇÃO FEDERAL DE EDUCAÇÃO, CIÊNCIA E TECNOLOGIA DO ESTADO DE GOIÁS 


\section{PLANO DE GERENCIAMENTO INTEGRADO DE RESÍDUOS SÓLIDOS PARA UMA INSTITUIÇÃO FEDERAL DE EDUCAÇÃO, CIÊNCIA E TECNOLOGIA DO ESTADO DE GOIÁS}

Dissertação apresentada ao Programa de PósGraduação em Gestão Pública, Mestrado Profissional em Gestão Pública, da Faculdade de Planaltina, da Universidade de Brasília (UnB) como requisito parcial à obtenção do título de Mestre em Gestão Pública.

Professora Orientadora: Dra. Lucijane Monteiro de Abreu. 
Teixeira dos Anjos, Juliana

TJ94p Plano De Gerenciamento Integrado de Resíduos Sólidos para uma Instituição Federal de Educação, Ciência e Tecnologia do Estado de Goiás / Juliana Teixeira dos Anjos; orientador Lucijane Monteiro de Abreu. -- Brasília, 2016.

$131 \mathrm{p}$.

Dissertação (Mestrado - Mestrado Profissional em Gestão Pública) -- Universidade de Brasília, 2016.

1. Resíduos Sólidos. 2. PGRS. 3. Administração Pública. 4. Instituto Federal. I. Monteiro de Abreu, Lucijane, orient. II. Título. 
JULIANA TEIXEIRA DOS ANJOS

\title{
PLANO DE GERENCIAMENTO INTEGRADO DE RESÍDUOS SÓLIDOS PARA UMA INSTITUIÇÃO FEDERAL DE EDUCAÇÃO, CIÊNCIA E TECNOLOGIA DO ESTADO DE GOIÁS
}

A Comissão Examinadora, abaixo identificada, aprova a Dissertação de Mestrado em Gestão Pública da Faculdade UnB de Planaltina, Universidade de Brasília do (a) aluno (a)

\author{
Juliana Teixeira dos Anjos \\ Dra. Lucijane Monteiro de Abreu \\ Professora-Orientadora
}

Dr. Elaine Nolasco Ribeiro

Professor-Examinador
Dr. Mário Lúcio de Ávila

Professor-Examinador
Dr. Jonilto Costa Souza

Professor-Examinador Suplente

Brasília, de de 


\section{AGRADECIMENTOS}

Há dois anos aceitei o desafio de ir além da Comunicação Social e embarcar no estudo da Gestão Pública, afinal, além de jornalista, meu ofício primeiro passou a ser o de servidora pública. E essa empreitada não teria sido possível sozinha, por isso os meus mais sinceros agradecimentos...

A Deus, pelas escolhas que me possibilita fazer e pelo caminho que me permite trilhar;

Ao meu marido, Rodrigo Invernizzi, meu companheiro, incentivador, suporte, meu amor. Você é responsável pelo meu sucesso;

Aos meus pais, Rosalvo e Lúcia, a quem devo minha gratidão maior por estar sempre ao meu lado e fazerem com que tudo sempre dê certo. Vocês são minha vida;

Aos amigos, Wagner e Giselle, que me abriram as portas de casa, me receberam e me acolheram durante o curso. Minhas semanas de aulas em Brasília teriam sido muito mais difíceis sem o apoio de vocês. Obrigada por estarem sempre presentes;

Ao amigo, Gustavo, que está sempre ao meu lado, me ajudando, me aguentando, me salvando. Seu apoio é sempre muito importante para mim;

Ao meu avô, Neto, que também é meu mestre, orientador e ídolo. Suas palavras sempre são as melhores, me orgulho de ser sua neta.

À orientadora, professora Lucijane Monteiro, pela indicação do tema e por possibilitar desenvolver uma pesquisa relacionada a uma demanda tão importante para administração pública atual, como é a questão do gerenciamento dos resíduos sólidos. Obrigada pela orientação e confiança no meu trabalho.

Ao magnífico reitor do IF Goiano, professor Vicente de Almeida, cuja gestão não mede esforços para promover a capacitação dos servidores da Instituição. 
Ao diretor-geral do Campus Trindade, professor Júlio César Garcia, e toda equipe da unidade, na pessoa da servidora Maria Alessandre de Sousa. Sem a receptividade, presteza e boa vontade dos servidores da unidade este trabalho não seria possível.

Obrigada a todos que, de alguma forma, contribuíram para o desenvolvimento e sucesso dessa pesquisa. 


\section{RESUMO}

A dissertação em questão visa desenvolver um Plano de Gerenciamento de Resíduos Sólidos para o Instituto Federal de Educação, Ciência e Tecnologia Goiano (IF Goiano) - Campus Trindade, a partir da discussão teórica a respeito da assunção de valores sustentáveis pela administração pública até a promulgação de legislações ambientais específicas e instrumentos para sua regulação. A metodologia consistiu em: revisão bibliográfica, com vistas ao adequamento da prática às exigências legais; identificação dos índices de consciência ambiental e consumo ecologicamente correto da comunidade acadêmica da Instituição; caracterização quali e quantitativa dos resíduos sólidos gerados na unidade; cálculo do índice de geração per capita; identificação dos problemas relacionados à coleta seletiva e análise das práticas de manuseio dos demais tipos de resíduos sólidos; e identificação e elaboração de ações alternativas para o gerenciamento de resíduos sólidos no Instituto, bem como a definição de indicadores para avaliação e monitoramento. Os resultados apontaram que os índices, tanto dos servidores quanto dos alunos, apresentaram potenciais traços de consciência ambiental e igual a 3,2, em contrapartida a fracos traços de consumo consciente, confirmando índice geral de 2,4. A quantidade média per capita de resíduos gerado diariamente no Campus Trindade mostrou-se inferior aos valores médios apresentados por outras instituições de ensino. Por fim, foram propostas as ações necessárias para elaboração e implantação de um Plano de Gerenciamento de Resíduos Sólidos na unidade.

Palavras-chave: Administração Pública. Resíduos Sólidos. PGRS. Instituto Federal 


\begin{abstract}
The dissertation in question aims to develop a Plan of Solid Waste Management for the Federal Institute of Education, Science and Goiano Technology (IF Goiano) - Campus Trinity, from the theoretical discussion of the assumption of sustainable values by the government until the promulgation specific environmental legislation and instruments for regulation. The methodology consisted of literature review, with a view to the practice of adequamento the legal requirements; identification of environmental awareness and ecofriendly consumption levels of the academic community of the institution; characterization qualitative and quantitative of solid waste generated in the unit; calculation of per capita generation rate; identification of problems related to selective collection and analysis of the handling practices of other types of solid waste; and identification and development of alternative actions for solid waste management at the Institute, as well as the definition of indicators for monitoring and evaluation. The results showed that the contents of both the servers and the students showed traces of potential environmental awareness and equal to 3.2, in contrast to weak traces of conscious consumption, confirming general index of 2.4. The average per capita amount of waste generated daily in the Campus Trinity was lower than the average values presented by other educational institutions. Finally, we proposed the necessary actions for the preparation and implementation of a Solid Waste Management Plan in the unit.
\end{abstract}

Keywords: Public Administration. Solid Waste. PGRS. Federal Institute. 


\section{LISTA DE ILUSTRAÇÕES}

Figura 1 - $\quad$ Organograma dos Planos de Gerenciamento de Resíduos Sólidos ........ 27

Figura 2 - Etapas para elaboração do PGRS ..................................................... 43

Figura 3 - $\quad$ Plantas por blocos do Campus Trindade …....................................... 55

Figura 4 - Banners no pátio central do Campus Trindade ................................... 67

Figura 5 - Panfleto de conscientização para separação do lixo distribuído para comunidade acadêmica da unidade ..................................................... 69

Figura 6- Gráfico da frequência da idade média dos servidores do Campus Trindade .................................................................................... 74

Figura 7 - Balança utilizada para pesagem dos resíduos utilizados para caracterização gravimétrica .......................................................... 77

Figura 8 - $\quad$ Abertura dos sacos de lixo para posterior processo de triagem .............. 78

Figura 9 - $\quad$ Triagem dos resíduos e separação em categorias ................................. 79

Figura 10 - Porcentagem da composição física dos resíduos sólidos presentes na amostra pesquisada ..................................................................... 80

Figura 11 - Garrafa pet descartada com bebida dentro ......................................... 82

Figura 12 - Disjuntor e pilhas encontradas no lixo comum da Instituição ................ 84

Figura 13 - Identificação das cores dos coletores segundo Resolução Conama $\mathrm{n}^{\circ}$

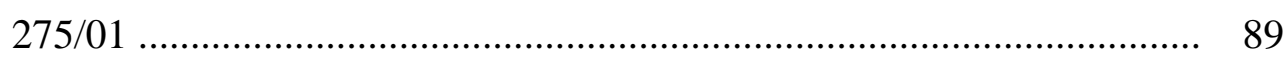

Figura 14 - Container destinado ao armazenamento externo .................................. 102

Figura 15 - Método utilizado no Ministério do Meio Ambiente para recolher papel para Reuso 


\section{LISTA DE TABELAS}

Tabela 1 - Mapeamento dos coletores e identificação se há separação ou não de resíduos recicláveis

Tabela 2 - Cálculo do grau de consciência ambiental dos servidores do Campus Trindade

Tabela 3 - Cálculo do grau de consciência ambiental dos alunos do Campus Trindade

Tabela 4 - Cálculo do grau de consciência ambiental dos servidores e alunos do Campus Trindade

Tabela 5 - Cálculo do grau de consumo ecologicamente correto dos servidores e alunos do Campus Trindade

Tabela 6 - Cálculo do grau de consumo ecologicamente correto dos alunos do Campus Trindade

Tabela 7 - Cálculo do grau de consumo ecologicamente correto dos servidores e alunos do Campus Trindade 73

Tabela 8 - $\quad$ Percentual por faixa etária dos servidores do Campus Trindade ............ 75

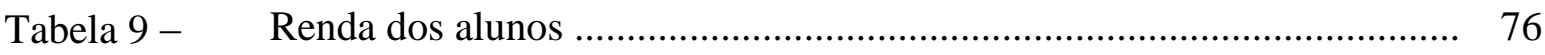

Tabela 10 - Quantidade de sacos plásticos recolhidos por dia no Campus Trindade . 78

Tabela 11 - Caracterização gravimétrica dos resíduos gerados no Campus Trindade 79

Tabela 12 - Determinação percentual da composição do lixo do Campus Trindade em 2015 


\section{LISTA DE QUADROS}

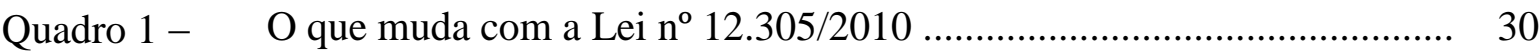

Quadro 2- Alocação de pesos e elaboração do cálculo dos graus de conscientização ecológica e de consumo ecologicamente correto 59

Quadro 3 - Grau de conscientização ambiental do consumidor ................................ 60

Quadro 4 - Grau de consumo ecologicamente correto dos consumidores ................ 60

Quadro 5 - $\quad$ Exemplos de materiais recicláveis e não recicláveis ............................. 90

Quadro 6 - Modelo de identificação utilizado no acondicionamento dos resíduos ... 91

Quadro 7 - $\quad$ Procedimentos para descarte do papel para reuso ................................. 108

Quadro 8 - Indicadores para monitoramento e avaliação do PGRS do Campus

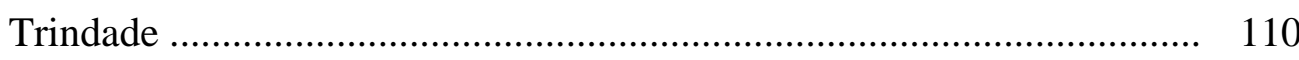




\section{SUMÁRIO}

1 INTRODUÇÃO ................................................................................................................12

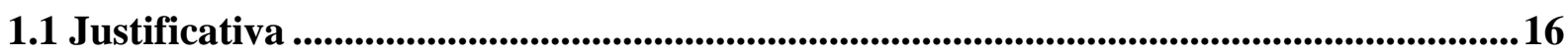

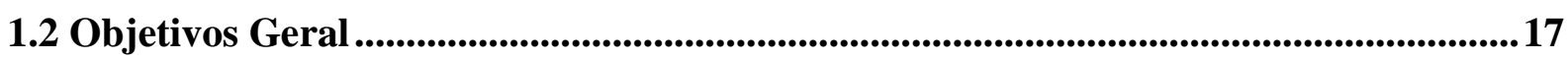

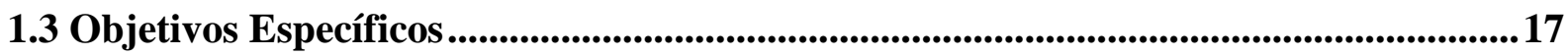

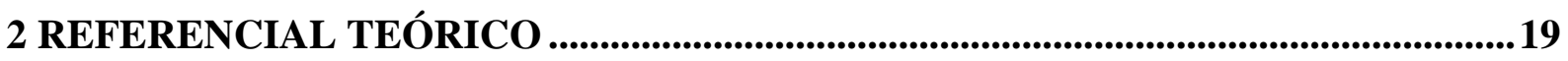

2.1 Administração Pública e a Temática Ambiental .......................................................19

2.2 Política Nacional de Resíduos Sólidos.......................................................................................224

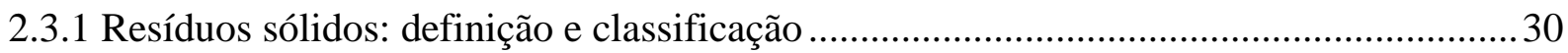

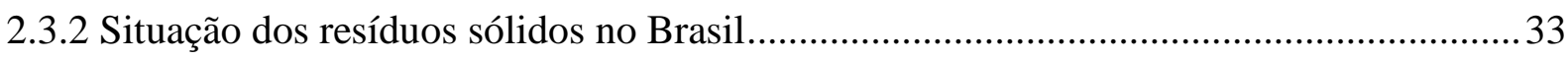

2.3.3 Principais legislações e normatizações ambientais brasileiras aplicadas à resíduos ........ 35

2.4 Plano de Gerenciamento de Resíduos Sólidos..........................................................38

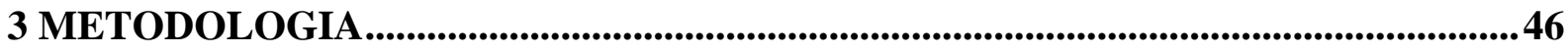

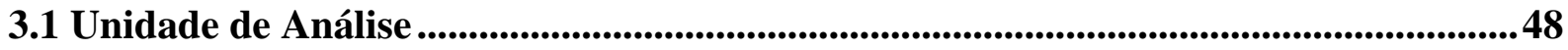

3.2 Estudo de Caso e Análise dos Dados..............................................................................51

3.2.1 Estrutura de gestão dos resíduos sólidos no IF Goiano - Campus Trindade ...................51

3.2.2 Instrumento de mensuração da consciência ambiental e consumo consciente.................52

3.3.3 Classificação, caracterização e composição gravimétrica dos Resíduos Sólidos e definição da taxa de geração per capita ..................................................................................55

4 APRESENTAÇÃO E DISCUSSÃO DE RESULTADOS..................................................59

4.1 Diagnóstico de Gestão dos Resíduos Sólidos Gerados no Campus Trindade ..............59

4.2 Grau de Consciência Ambiental e Consumo Consciente ..............................................69

4.3 Análise do Perfil dos Servidores e Alunos do Campus Trindade ................................71

4.4 Caracterização dos Resíduos Sólidos........................................................................73

5 ELABORAÇÃO DO PLANO DE GESTÃO DE RESÍDUOS SÓLIDOS DO IF

GOIANO - CAMPUS TRINDADE ............................................................................8

5.1 Diretrizes do Gerenciamento de Resíduos Sólidos do Campus Trindade ....................84

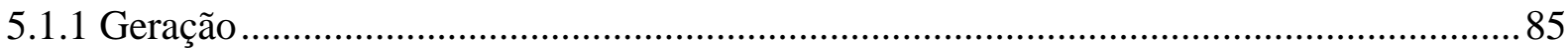

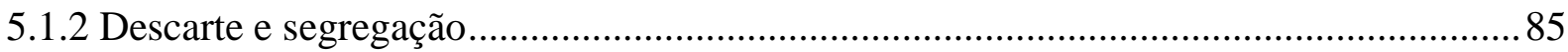

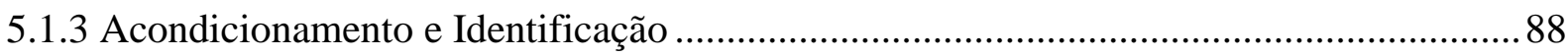

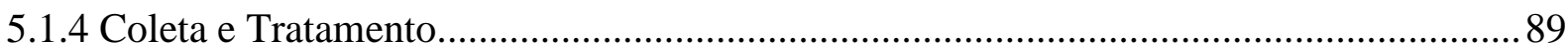

5.1.5 Armazenamento Temporário e Transporte Interno .................................................... 90 
5.1.6 Armazenamento e Transporte Externos 90

5.1.7 Disposição Final

5.2 Procedimentos para implantação do Plano de Gerenciamento de Resíduos Sólidos do

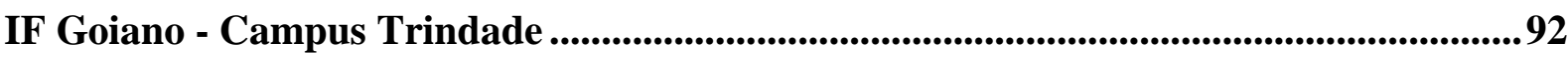

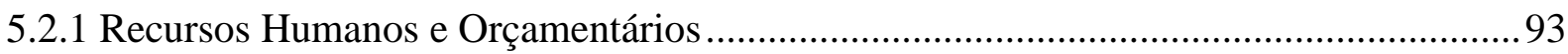

5.2.2 Educação Ambiental e Conscientização.......................................................................... 94

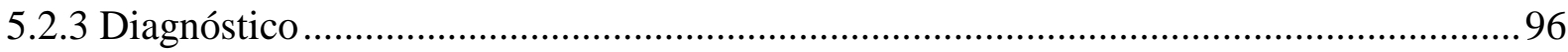

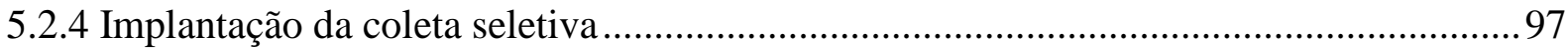

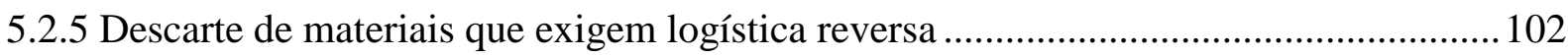

5.2.6 Elaboração de uma Política Institucional Ambiental .................................................. 103

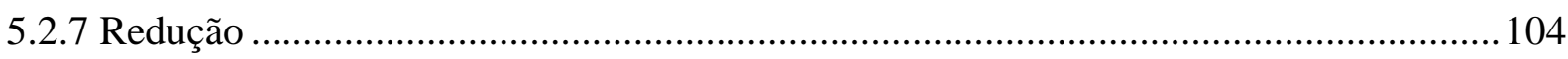

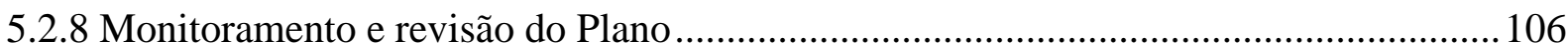

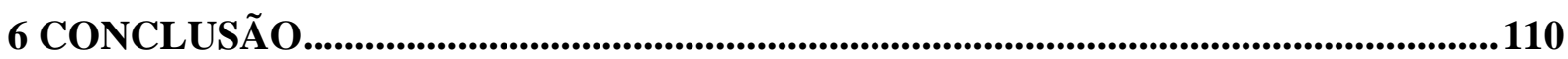

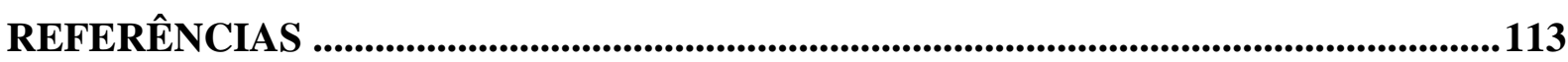

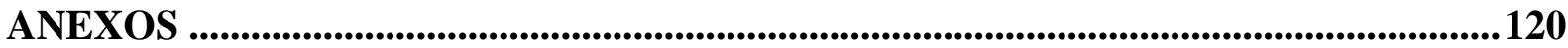

Anexo A - Questionário 1 - Diagnóstico da situação do manejo de resíduos sólidos .... 120 Anexo B - Questionário 2 - Grau de consciência ambiental e de consumo ecologicamente

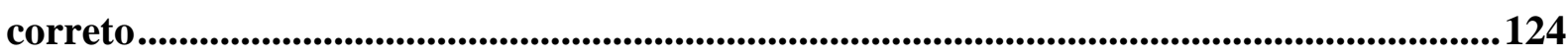

Anexo C - Lista de Cooperativas de Catadores de Materiais Recicláveis de Goiânia ..126

Anexo D - Modelo da Agenda Ambiental da Administração Pública (A3P) para

Relatório de Gerenciamento de Resíduos Sólidos ..................................................................... 128 


\section{INTRODUÇÃO}

O crescimento econômico e populacional aliado ao elevado consumo são fatores determinantes para o aumento da geração dos resíduos, que se transformaram em um dos principais problemas ambientais da atualidade. A gestão adequada dos resíduos sólidos ocupa posição de destaque no que se refere à promoção de práticas voltadas para o desenvolvimento sustentável, isso porque "sua geração, descarte e disposição inadequados provocam diversos impactos ambientais, sociais, econômicos e de saúde pública" (GONÇALVES et al., 2010, p. 80).

O crescimento das cidades brasileiras não foi acompanhado do desenvolvimento em infraestruturas e serviços urbanos, o que implicou diretamente em problemas relacionados ao manejo e destinação final dos resíduos sólidos no país. Em decorrência, a temática assumiu importância estratégica tanto nas gestões da esfera privada, quanto das administrações públicas, o que exigiu das entidades reguladoras, legislativas e governamentais o estabelecimento de quadros legais apropriados, bem como a vigilância de sua aplicação.

Assim, após 21 anos de discussões no Congresso Nacional, foi aprovada, em 2010, a Lei $n^{\text {o }}$ 12.305, que instituiu a Política Nacional de Resíduos Sólidos (PNRS). Essa normativa representou um novo marco regulatório para a gestão dos resíduos no país e representou, paradoxalmente, uma conquista e um desafio para toda a sociedade brasileira. Uma conquista, pois, como política, funcionou (e funciona) de modo a normatizar e orientar as ações estratégicas na área ambiental, possibilitando um desenvolvimento ambiental sustentável e socialmente justo. Um desafio, pois passou a exigir das instituições públicas "adequação das estruturas e criação de uma nova cultura institucional para a segregação e destinação ambientalmente adequada dos resíduos sólidos produzidos” (MMA, 2014a, p. 5). 
A aprovação da PNRS qualificou as discussões e ações referentes ao tema, colocando a correta e eficiente gestão de resíduos como um dos principais desafios do século XXI. Por meio dessa Política, foi possível à União, Estados, Municípios, setor produtivo e sociedade em geral se articularem institucionalmente na busca de soluções para problemas ambientais que afetam a qualidade de vida dos brasileiros, quer seja os de proporções locais ou de alcance nacional (MMA, 2012). Além de reunir o conjunto de princípios, objetivos e diretrizes referentes à gestão integrada e ao gerenciamento ambientalmente adequado dos resíduos sólidos, a PNRS apresenta como principais instrumentos a coleta seletiva, a educação ambiental e os planos de resíduos sólidos, sendo este último a base do objeto de pesquisa deste trabalho.

Os Planos de Gerenciamento de Resíduos Sólidos (PGRS) são ferramentas que corroboram para o correto gerenciamento e gestão integrada dos resíduos sólidos, contribuindo para manter as organizações em consonância com os aspectos legais previstos pela legislação. De acordo com a Lei n ${ }^{\circ} 12.305$, o modelo de gestão dos resíduos proposto por um PGRS deve seguir a seguinte ordem de prioridade: não geração, redução, reutilização, reciclagem, tratamento dos resíduos sólidos e disposição final ambientalmente adequada dos rejeitos, além de priorizar o trabalho de cooperativas ou associações de catadores de materiais recicláveis e promover a inclusão socioprodutiva dessa classe trabalhadora, conforme prevê o decreto $\mathrm{n}^{\mathrm{o}} 5.940 / 2006 .{ }^{1} \mathrm{O}$ desenvolvimento desses planos pelo poder público contribui ainda, para a promoção de ações exemplares que tenham como fim a sustentabilidade.

Desde que entrou em vigor, a PNRS só entrou em vigor em agosto de 2014 têm demonstrado seu elevado grau de importância ao movimentar os setores envolvidos no

De acordo com o Decreto $n^{\circ} 5.940$, de 25 de outubro de 2006, cada órgão e entidade da administração pública federal direta e indireta, deverá realizar a separação dos resíduos recicláveis descartados na fonte geradora e destinar às associações e cooperativas dos catadores de materiais recicláveis, processo definido no citado decreto como Coleta Seletiva Solidária (CSS). 
sentido de repensarem suas ações em detrimento do cumprimento da lei. Neste movimento, a preocupação com a gestão de resíduos sólidos vem ganhando espaço crescente na área da Educação, principalmente entre as instituições responsáveis pela oferta de ensino técnico e superior, que além da formação em sala de aula, oferecem práticas de campo e laboratoriais que acabam por aumentar a quantidade, o volume e a diversidade dos fluxos de resíduos gerados.

Além disso, as instituições de ensino superior e técnico são responsáveis por cerca de 1\% dos resíduos químicos gerados no Brasil. Apesar de parecer pequeno, este índice torna-se preocupante, em decorrência da persistência de tais resíduos no ambiente, o que acarreta em graves prejuízos à fauna e à flora (FARIA; OLIVEIRA; SANTOS, 2010). Assim, compondo essa realidade, o Instituto Federal de Educação, Ciência e Tecnologia Goiano (IF Goiano), instituição pública responsável pela oferta de ensino superior, básico e profissional, participa, desde novembro de 2012, da Agenda Ambiental da Administração Pública (A3P). Esse programa, cuja adesão é voluntária, é uma ação do Ministério do Meio Ambiente e representa a principal ferramenta de gestão socioambiental da Administração Pública Brasileira. A A3P está estruturada em seis eixos temáticos, sendo um deles referente ao gerenciamento de resíduos sólidos, incluindo ainda: uso racional dos recursos naturais e bens públicos, qualidade de vida no ambiente de trabalho, sensibilização e capacitação dos servidores, contratações públicas sustentáveis e construções sustentáveis.

No IF Goiano, a adesão ao Programa correspondeu ao início do processo de institucionalização das ações ambientais, isso porque, antes da A3P cada campus desenvolvia suas próprias atividades de maneira independente e sem conhecimento do que estava sendo feito nas outras unidades da Instituição. Com a adesão, foi criada uma comissão com representantes dos cinco campi em funcionamento na época e reitoria e a partir de então o planejamento passou a ser coletivo. 
O IF Goiano é uma autarquia federal detentora de autonomia administrativa, patrimonial, financeira, didático-pedagógica e disciplinar, equiparado às universidades federais. Oferece educação superior, básica e profissional, pluricurricular e multicampi, especializada em educação profissional e tecnológica nas diferentes modalidades de ensino. Está presente nos campi das cidades goianas de Campos Belos, Catalão, Cristalina, Ceres, Hidrolândia, Ipameri, Iporá, Morrinhos, Posse, Rio Verde, Trindade e Urutaí. Em quase três anos de participação do IF Goiano na A3P muito pode se destacar, pois a adesão representou o primeiro passo no sentido da institucionalização da responsabilidade socioambiental com vistas ao desenvolvimento sustentável.

Nesse período foram realizadas campanhas de sensibilização, ações de incentivo a redução do consumo de água, energia e incentivo a não utilização de copos descartáveis nas unidades, plantio de árvores, além de projetos ambientais com foco na compostagem de resíduos orgânicos. Como resultado, em outubro de 2014, o IF Goiano foi certificado pelo Ministério do Meio Ambiente com o Selo A3P de Sustentabilidade na Administração Pública. O Selo A3P Verde, como é designado, é conferido em reconhecimento às instituições públicas pelo empenho na implementação da Agenda Ambiental da Administração Pública (A3P).

Mas o fato é que muito tem que se avançar. O que se observa atualmente é uma realidade formada por um corpo administrativo, docente, discente e terceirizado sem formação na temática ambiental, seja por falta de conhecimento ou engajamento pessoal, tendo em vista o processo de sensibilização e conscientização não consolidado. Além disso, a destinação final ambientalmente correta do resíduo reciclável, segundo prevê o decreto $\mathrm{n}^{\circ}$ 5.940/2006, é apontada como um dos principais entraves para a realização da coleta seletiva, uma vez que em algumas cidades onde os campi estão instalados não possuem cooperativas de catadores de materiais recicláveis. 
É partindo deste panorama e com o objetivo de oferecer um suporte bibliográfico e metodológico para a questão dos resíduos sólidos na administração pública federal que o projeto em questão visa desenvolver um Plano de Gerenciamento de Resíduos Sólidos (PGRS) para um campus do Instituto Federal Goiano. A intenção é que esta metodologia possa servir de modelo para as outras unidades da Instituição, tanto as que já estão em funcionamento, quanto àquelas que estão em construção, e também para outros Institutos da Rede, uma vez que modelos e trabalhos nessa área ainda são bastante restritos. Além disso, o trabalho objetiva oferecer um referencial teórico capaz de fomentar a discussão referente à implantação e gerenciamento de políticas e programas a partir da descentralização dos entes federativos (União, Estado e Municípios).

\subsection{Justificativa}

Apesar da adesão à Agenda Ambiental da Administração Pública (A3P) ser de caráter voluntário, a aprovação da Política Nacional de Resíduos Sólidos tornou o gerenciamento dos resíduos sólidos - que é um dos eixos temáticos da A3P - obrigatório nas instituições públicas. Assim o projeto se justifica ao dar cumprimento à exigência legal. Somado ao cumprimento da lei, o desenvolvimento de um PGRS se faz importante como forma de garantir a qualidade dos serviços prestados, sem implicação de impactos negativos ao ambiente no qual o Instituto está inserido. Além disso, o fato de instituições públicas de ensino assumirem importante papel na responsabilização de ações ambientais adequadas, por estarem ligadas à educação e formação cidadã, justifica e reforça ainda mais a necessidade de elaboração de um PGRS, para "servirem de exemplo no cumprimento da legislação, saindo do campo teórico para a prática" (TAUCHEN; BRANDLI, 2006, p. 505). 
A pesquisa será desenvolvida no Instituto Federal de Educação, Ciência e Tecnologia Goiano (IF Goiano) - Campus Trindade. A escolha deste campus se baseou no fato desta unidade apresentar condições mais favoráveis para implantação de uma nova cultura institucional, uma vez que suas atividades foram iniciadas recentemente, em janeiro de 2015 . Além disso, faz parte do planejamento institucional projetar este unidade como modelo em sustentabilidade, com desenvolvimento de projetos voltados para o uso da energia solar e reaproveitamento da água da chuva, além da correta gestão de resíduos sólidos. Outro ponto refere-se ao fato desta unidade ser a primeira do IF Goiano a estar inserida em um ambiente urbano e apresentar formação na temática industrial, diferente das demais que estão localizadas na zona rural e focadas nos problemas e soluções agrícolas. Tal fato reforça a necessidade de ser iniciar ações específicas para essa nova realidade.

\subsection{Objetivos Geral}

Com base na justificativa apresentada, o presente projeto tem como objetivo geral elaborar um Plano de Gerenciamento de Resíduos Sólidos (PGRS) em uma Instituição de Educação, Ciência e Tecnologia, localizada no Estado de Goiás, visando atendimento da legislação ambiental e normas pertinentes, bem como a capacitação educacional e operacional de funcionários e estudantes no correto manejo dos resíduos sólidos gerados.

\subsection{Objetivos Específicos}

O objetivo geral será alcançado a partir dos seguintes objetivos específicos: 
- levantar experiências e práticas à luz da legislação vigente aplicada a resíduos sólidos no Brasil;

- conhecer o nível de consciência ambiental e de consumo ecologicamente correto da comunidade acadêmica do IF Goiano - Campus Trindade;

- caracterizar quali e quantitativamente os resíduos sólidos e fontes geradoras na unidade;

- identificar os desafios para implantação de um programa de Coleta Seletiva de resíduos recicláveis no Campus Trindade e analisar as práticas de manuseio dos demais tipos de resíduos sólidos;

- identificar / elaborar indicadores para avaliação e monitoramento;

- propor medidas para subsidiar a elaboração e implantação do Plano de Gerenciamento de Resíduos Sólidos para o Campus Trindade. 


\section{REFERENCIAL TEÓRICO}

A história da administração pública se constitui a partir da busca de instrumentos para melhorar a gestão governamental e a implementação de políticas públicas. A ideia de um novo modelo de desenvolvimento para o século XXI, que compatibilizasse as dimensões econômica, social e ambiental, impulsionou investimentos em projetos direcionados a ações caracterizadas como de responsabilidades sociais, trazendo a tona discussões referentes ao papel social das organizações, especificamente no que concerne às questões ambientais. Assim, o referencial teórico abordado a seguir, traçará um paralelo entre a história da administração pública, a instituição de regulamentação específica e os e os esforços de órgãos e entidades públicas para a promoção do desenvolvimento sustentável como ferramenta estratégica nas gestões de órgãos e entidades públicos, além de se adequarem às exigências das leis.

\subsection{Administração Pública e a Temática Ambiental}

Neste cenário e entendendo a Gestão Ambiental como um conjunto de políticas, programas e práticas que levam em conta a saúde e a segurança das pessoas e a proteção do meio ambiente (IBAMA, 2006), a Administração Pública passa a ser responsável direta pela promoção do desenvolvimento sustentável, assumindo a Gestão Ambiental como ferramenta administrativa estratégica. Essa nova postura gerou uma série de instrumentos que agregaram fatores ambientais à execução de Planos, Projetos e Programas (PPPs) Públicos, bem como exigiu das entidades reguladoras, legislativas e governamentais o estabelecimento de quadros legais apropriados, bem como a vigilância de sua aplicação. 
Essa mudança passa a creditar às políticas públicas - entendidas como o conjunto de orientações e ações de um governo com vistas ao alcance de determinados objetivos, com interferência na atividade econômica, através de instrumentos de controle econômico - a expectativa de reversão do atual quadro de degradação dos recursos naturais. Não se trata mais apenas de estabelecer padrões para emissões de poluentes ou de fiscalizar o cumprimento de normas técnicas e punir aqueles que, infringindoas, poluem o meio ambiente, embora não se possa prescindir dessas medidas. Aos governos, em especial, mas também às sociedades, de forma ampla, é atribuída a responsabilidade pela promoção de uma atitude nova frente aos recursos naturais e problemas ambientais. (MACHADO, 2003, p. 24).

A adoção de uma consciência socioambiental emergiu na década de 80 como canal de abertura reconhecido para a participação sociopolítica e exercício da cidadania no processo de formação das decisões políticas. A própria Constituição Federal de 1988, que representou um marco no que diz respeito ao estabelecimento de novas diretrizes para a efetivação de políticas públicas brasileiras, apresenta artigo específico para tratar do meio ambiente. Mas foi só a partir de 1990, que o número de iniciativas e discussões relacionadas ao tema se expandiu até pautarem a agenda internacional, não apenas restrita ao setor empresarial, mas também no âmbito das instituições governamentais que, cada vez mais, têm participado como ator do processo, inclusive criando estruturas de governo específicas para tratar do tema.

\footnotetext{
As empresas e instituições do setor público, particularmente as que têm como missão direta promover o bem-estar da sociedade, deveriam ser as primeiras a tomar a iniciativa de implantar um sistema eficiente de gestão ambiental. Aos fatores sociais associados à preservação ambiental e à saúde da população, somam-se os efeitos da melhor utilização de recursos públicos, pois a eco eficiência se fundamenta na racionalidade das decisões, na análise de custo e benefício das medidas a serem implementadas. (BARATA; KLIGERMAN; MINAYO-GOMES, 2007, p. 169).
}

Assim, a administração pública tem assumido a responsabilidade de contribuir para o enfrentamento das questões ambientais, buscando estratégias inovadoras que repensem, principalmente, os atuais padrões de produção e consumo e os objetivos econômicos. Tal percepção é observada a partir da motivação demonstrada pelas instituições públicas em implementar iniciativas específicas e desenvolver programas e projetos que promovam a 
discussão sobre desenvolvimento e adoção de uma política de responsabilidade socioambiental do setor público.

\begin{abstract}
Portanto, o Estado brasileiro ao praticar a gestão ambiental, está mediando disputas pelo acesso e uso dos recursos ambientais, em nome do interesse público, numa sociedade complexa, onde o conflito é inerente a sua existência. Neste processo, ao decidir sobre a destinação dos bens ambientais (uso, não uso, como usa, quem usa, quando usa, para que usa, onde usa) o Poder Público, além de distribuir custos e benefícios, de modo assimétrico no tempo, no espaço e na sociedade está explicitando, também, o caráter da sustentabilidade que assume, cuja noção comporta variadas possibilidades de atribuição de significados. (QUINTAS, 2011).
\end{abstract}

É importante destacar também que a adoção de políticas de cunho ambiental pelas instituições públicas gera economia dos recursos públicos, na medida em que esses recursos serão gastos com maior eficiência, o que vai de encontro aos preceitos legais que regem o funcionalismo público brasileiro. Mais que uma exigência social e legal, a gestão pública com ênfase na responsabilidade socioambiental representa estratégia administrativa fundamental a ser adotada pelos órgãos públicos como forma de contribuir para a conservação do meio ambiente, garantindo assim, uma imagem ética e politicamente correta junto aos usuários dos serviços públicos e a sociedade como um todo (VIEIRA, 2013). Assumir tal postura significa adotar princípios sustentáveis por meio de mudanças de costumes e práticas consolidados ao longo dos anos. Nesse sentido, ultrapassar o discurso meramente teórico e concretizar a boa intenção num compromisso sólido constitui o grande desafio colocado atualmente à administração pública brasileira.

É nesse contexto que, em 1999, o Ministério do Meio Ambiente (MMA), inicia um projeto com vistas à construção de uma nova cultura institucional a partir da adoção de novos padrões de produção e consumo sustentáveis dentro da administração pública federal. Em decorrência do bom desempenho do projeto, dois anos após seu lançamento, foi criado o Programa Agenda Ambiental na Administração Pública (A3P), tendo como principal desafio a promoção da Responsabilidade Socioambiental como política governamental. 
Faz-se relevante destacar que, nesse contexto, a Responsabilidade Socioambiental configura-se como um modelo de gestão responsável por agregar desempenhos ambientais, econômicos e sociais diferenciados às Instituições/Organizações que as adotam. Segundo prevê a ISO 26.000 (ABNT, 2010), que trata das diretrizes sobre Responsabilidade Social, as decisões e atividades da organização socialmente responsável podem trazer uma contribuição significativa para o desenvolvimento sustentável. Uma instituição que define a Responsabilidade Social como política deve estar atenta "aos compromissos éticos, promoção da cidadania, valorização da cooperação social e da solidariedade e transparência de suas ações, preconizados por essa normatização" (CABESTRÉ; GRAZIADEI; POLESEL FILHO, 2008). Assim, a A3P atua como um instrumento de gestão institucional que busca a integração entre a agenda de crescimento econômico e o desenvolvimento sustentável por meio da inserção de princípios e práticas de sustentabilidade socioambiental no âmbito da administração pública (MMA, 2009).

\begin{abstract}
A A3P tem como objetivo estimular os gestores públicos a incorporar princípios e critérios de gestão socioambiental em suas atividades rotineiras, levando à economia de recursos naturais e à redução de gastos institucionais por meio do uso racional dos bens públicos, da gestão adequada dos resíduos, da licitação sustentável e da promoção da sensibilização, capacitação e qualidade de vida no ambiente de trabalho. (MMA, 2009, p. 7).
\end{abstract}

A A3P é um referencial de Responsabilidade Socioambiental e pode ser desenvolvida em toda a administração pública, no âmbito de governo (Municipal, Estadual e Federal), na esfera dos três poderes (Executivo, Legislativo e Judiciário), podendo ainda, ser usada como modelo por outros segmentos da sociedade. A Agenda atua com base nos seguintes eixos: uso racional dos recursos naturais e bens públicos, gerenciamento de resíduos sólidos, qualidade de vida no ambiente de trabalho, sensibilização e capacitação dos servidores, contratações públicas sustentáveis e construções sustentáveis (MMA, 2014b). Já as diretrizes do programa 
foram elaboradas com base nas recomendações presentes no capítulo IV da Agenda 21, fruto da ECO-92, no Princípio 8 da Declaração do Rio/92 e na Declaração de Johanesburgo.

\begin{abstract}
A A3P reconhece o importante papel exercido pela administração pública enquanto consumidora e usuária de recursos naturais e a sua capacidade de indução de novos padrões socioambientais. $\mathrm{O}$ atendimento e a satisfação dos interesses coletivos, enquanto finalidade da administração pública, faz com que a mesma tenha a obrigação de dar o exemplo para todos os setores da sociedade, promovendo o desenvolvimento e o crescimento sustentáveis. (MMA, 2009, p. 86).
\end{abstract}

A participação na A3P é voluntária, sem natureza impositiva e regulatória, e pode ser estabelecida de maneira formal por meio da assinatura de um Termo de Adesão, cuja finalidade é integrar esforços para o desenvolvimento de projetos destinados à implementação do Programa. Assim, fica estabelecido que, ao assinar o termo, a Instituição se compromete com a agenda socioambiental e com a gestão transparente do Programa. Outra forma de participação acontece por meio da Rede A3P, que consiste em um canal de comunicação "permanente e de troca de experiências que tem como intuito promover o intercâmbio técnico, difundir informações sobre temas relevantes à Agenda e sistematizar dados e informações sobre o desempenho ambiental das instituições parceiras" (MMA, 2014b).

O Instituto Federal de Pesquisa, Ciência e Tecnologia Goiano (IF Goiano), que é objeto da presente pesquisa, conta também com outros programas e ferramentas da administração pública para promoção da responsabilidade socioambiental, que são: o Plano de Logística Sustentável (PLS) e o Projeto Esplanada Sustentável (PES).

O Plano de Logística Sustentável (PLS) são ferramentas de planejamento que permitem aos órgãos ou entidades estabelecer práticas de sustentabilidade e racionalização de gastos e processos na Administração Pública. Os PLS foram criados pelo art. 16, do Decreto $\mathrm{n}^{\circ}$ 7.746, de 5 de junho de 2012, e as regras para elaboração dos mesmos estão definidas pela Instrução Normativa SLTI/MP nº 10, de 12 de novembro de 2012. De acordo com este último documento, os PLS devem conter, minimamente, a atualização do inventário de bens e 
materiais do órgão e identificação de similares de menor impacto ambiental para substituição; as práticas de sustentabilidade e de racionalização do uso de materiais e serviços; as responsabilidades, metodologia de implementação e avaliação do plano; e ações de divulgação, conscientização e capacitação.

O Projeto Esplanada Sustentável (PES) é uma iniciativa conjunta de quatro Ministérios: Planejamento; Meio Ambiente; Minas e Energia; e Desenvolvimento Social e Combate à Fome, que visa Incentivar Órgãos e Instituições Públicas Federais a adotarem modelo de Gestão Organizacional e de Processos estruturado na implementação de ações voltadas ao uso racional de recursos naturais, promovendo a sustentabilidade ambiental e socioeconômica na Administração Pública Federal. As ações do Projeto buscam promover a mudança principalmente sobre as seguintes perspectivas: visão de gestão, cultura do gasto, valorização do órgão, do gestor e das boas práticas e combate ao desperdício.

\subsection{Política Nacional de Resíduos Sólidos}

A Política Nacional de Resíduos Sólidos, regulamentada pelo Decreto no 7.404 de 23 de dezembro de 2010, constitui a principal base legal para o desenvolvimento desta pesquisa e define os princípios, objetivos, instrumentos, metas e ações que os governos devem adotar com o intuito de promover uma gestão integrada e ambientalmente adequada dos resíduos sólidos, indicando as responsabilidades dos geradores, do poder público e dos consumidores.

É importante ressaltar que a Política Nacional do Meio Ambiente consagrou um princípio muito importante quanto à responsabilidade do poluidor. Em questões ambientais ela é objetiva, isto é, independe da existência de dolo (intenção de causar o dano) ou culpa (negligência, imperícia ou imprudência). O poluidor é responsável pelos danos causados ao Meio Ambiente e a terceiros, devendo repará-los. (MMA, 2009, p. 15). 
Dentre os objetivos estabelecidos pelo artigo $7^{\circ}$ da Lei $n^{\circ} 12.305$ destaque para a ordem de prioridade para a gestão dos resíduos, que indica a: não geração, redução, reutilização, reciclagem, tratamento dos resíduos sólidos e disposição final ambientalmente adequada dos rejeitos. Com a Lei, a adoção dessa hierarquia deixa de ser voluntária e passa a ser obrigatória. O Ministério do Meio Ambiente (2011), explica que o respeito a esta procedência, segundo verificado pela experiência de países mais desenvolvidos, é responsável por um "melhor resultado em relação à eficiência energética exigida no novo marco legal brasileiro para o saneamento, gestão de resíduos e combate às mudanças climáticas" (MMA, 2011, p. 23). Os objetivos da PNRS contemplam a realidade das Instituições Federais de Ensino Superior (Ifes), podendo ser aplicado no gerenciamento de resíduos sólidos das mesmas. São objetivos previstos na lei e podem ser aplicados diretamente ao cenário das Ifes:

I - proteção da saúde pública e da qualidade ambiental;

II - não geração, redução, reutilização, reciclagem e tratamento dos resíduos sólidos, bem como disposição final ambientalmente adequada dos rejeitos;

III - estímulo à adoção de padrões sustentáveis de produção e consumo de bens e serviços; IV - adoção, desenvolvimento e aprimoramento de tecnologias limpas como forma de minimizar impactos ambientais;

V - redução do volume e da periculosidade dos resíduos perigosos;

VII - gestão integrada de resíduos sólidos;

VIII - articulação entre as diferentes esferas do poder público, e destas com o setor empresarial, com vistas à cooperação técnica e financeira para a gestão integrada de resíduos sólidos;

IX - capacitação técnica continuada na área de resíduos sólidos;

XI - prioridade, nas aquisições e contratações governamentais, para: 
a) produtos reciclados e recicláveis;

b) bens, serviços e obras que considerem critérios compatíveis com padrões de consumo social e ambientalmente sustentáveis;

XII - integração dos catadores de materiais reutilizáveis e recicláveis nas ações que envolvam a responsabilidade compartilhada pelo ciclo de vida dos produtos;

Já entre os princípios da PNRS, vale ressaltar a necessidade de se estabelecer uma visão sistêmica que contemple os aspectos ambientais, sociais, cultural, econômicos, tecnológicos e de saúde pública envolvidos no processo de gestão de resíduos. Outro princípio importante refere-se ao reconhecimento dos resíduos sólidos como sendo passiveis de reutilização e reciclagem como um bem de valor econômico e social (LIMA, 2014).

Um resumo dos principais aspectos a serem considerados na gestão dos resíduos sólidos antes e após a aprovação da Lei nº 12.305/10 está apresentado no Quadro 1.

Quadro 1 - O que muda com a Lei $\mathrm{n}^{\circ}$ 12.305/2010

\begin{tabular}{|l|l|}
\hline \multicolumn{1}{|c|}{ ANTES } & \multicolumn{1}{c|}{ DEPOIS } \\
\hline $\begin{array}{l}\text { Não há prioridade para a questão dos resíduos } \\
\text { sólidos urbanos. }\end{array}$ & $\begin{array}{l}\text { Torna-se responsabilidade dos municípios o plano } \\
\text { de metas sobre resíduos, com participação dos } \\
\text { catadores. }\end{array}$ \\
\hline $\begin{array}{l}\text { Disposição final inadequada dos resíduos sólidos } \\
\text { em lixões na maioria dos municípios. }\end{array}$ & $\begin{array}{l}\text { Erradicação dos lixões em até quatro anos, a } \\
\text { contar da promulgação da Lei. }\end{array}$ \\
\hline $\begin{array}{l}\text { Não existe prioridade no tratamento adequado } \\
\text { para os resíduos sólidos orgânicos. }\end{array}$ & $\begin{array}{l}\text { A chamada compostagem passa a ser um requisito } \\
\text { obrigatório para o tratamento dos resíduos sólidos } \\
\text { orgânicos. }\end{array}$ \\
\hline $\begin{array}{l}\text { As escassas ações de coleta seletiva, além do alto } \\
\text { custo, são ineficazes par reduzir os volumes de } \\
\text { resíduos sólidos a serem dispostos em aterros } \\
\text { sanitários. }\end{array}$ & $\begin{array}{l}\text { A coleta seletiva torna-se obrigatória, devendo-se } \\
\text { controlar seus custos e fiscalizar a qualidade do } \\
\text { serviço. }\end{array}$ \\
\hline $\begin{array}{l}\text { Os catadores executam suas atividades na } \\
\text { informalidade, estando expostos a condições } \\
\text { insalubres de trabalho. }\end{array}$ & $\begin{array}{l}\text { Incentivo ao cooperativismo e regulamentação da } \\
\text { profissão de catador. As Cooperativas serão } \\
\text { contratadas pelos municípios para coleta e } \\
\text { reciclagem. }\end{array}$ \\
\hline
\end{tabular}


(Continuação Quadro 1 - O que muda com a Lei $\mathrm{n}^{\circ}$ 12.305/2010)

\begin{tabular}{|l|l|}
\hline \multicolumn{1}{|c|}{ ANTES } & \multicolumn{1}{c|}{ DEPOIS } \\
\hline $\begin{array}{l}\text { Além de pouca disponibilidade, os materiais } \\
\text { recicláveis presentes no mercado apresentam } \\
\text { baixa qualidade. }\end{array}$ & $\begin{array}{l}\text { Aumenta-se a quantidade e melhora-se a } \\
\text { qualidade da matéria-prima reciclada. }\end{array}$ \\
\hline $\begin{array}{l}\text { Inexistência de lei nacional para orientar os } \\
\text { investimentos das empresas na gestão dos } \\
\text { resíduos sólidos. }\end{array}$ & $\begin{array}{l}\text { Passa a existir marco legal para estimular } \\
\text { açóngariais voltadas à gestão dos } \\
\text { resíduos sólidos. }\end{array}$ \\
\hline $\begin{array}{l}\text { Baixa adesão da sociedade na separação do } \\
\text { lixo reciclável nas residências. }\end{array}$ & $\begin{array}{l}\text { Adoção de responsabilidade compartilhada } \\
\text { faz com que a separação do lixo reciclável } \\
\text { seja mais criteriosa nas residências. }\end{array}$ \\
\hline $\begin{array}{l}\text { Falta de informação técnica sobre os resíduos } \\
\text { sólidos gerados no Brasil. }\end{array}$ & $\begin{array}{l}\text { Criação de sistemas de informação sobre } \\
\text { resíduos sólidos, para auxiliar sua gestão. }\end{array}$ \\
\hline $\begin{array}{l}\text { Inexistência da política de logística reversa }{ }^{2} \\
\text { associada à produção. }\end{array}$ & $\begin{array}{l}\text { Empresas passam a ser responsáveis pelos } \\
\text { resíduos gerados e pelo descarte de seus } \\
\text { produtos. }\end{array}$ \\
\hline
\end{tabular}

Fonte: Montagna (2012).

Na prática, alguns pontos a serem implementados em decorrência da promulgação da Lei devem ser destacados. O primeiro refere-se à prorrogação do prazo de extinção dos lixões. A Política Nacional de Resíduos Sólidos determinava até agosto de 2012 para os municípios darem a destinação final adequada aos resíduos sólidos, e até agosto de 2014 para eliminarem os lixões a céu aberto. Mas, em setembro de 2015, o Senado aprovou um projeto de prorrogação escalonada desse prazo, passando para 2018 a 2021, dependendo do perfil da cidade. Essa medida foi necessária, pois a maior parte das prefeituras não conseguiu cumprir a meta e ficaram impedidas de receber recursos federais para limpeza urbana.

Outro ponto refere-se à obrigatoriedade da coleta seletiva, sendo esta um dos principais instrumentos da PNRS. A Lei 12.305 prevê sua implantação, incluindo o controle de seus custos e fiscalização da qualidade de suas ações, em todos os níveis, desde o nacional, passando pelos regionais e municiais, até os setoriais. Além da coleta seletiva, o artigo 8 da

A Logística Reversa é um instrumento de desenvolvimento econômico e social que permite a coleta do que foi consumido e sua restituição ao setor empresarial, para reaproveitamento no mesmo ciclo produtivo ou em outros ciclos. Trata-se do caminho de volta que o produto percorre, após ser vendido e consumido. Segundo a PNRS, a logística reversa é obrigatória para: 1) agrotóxicos, seus resíduos e embalagens; 2) pilhas e baterias; 3) pneus; 4) óleos lubrificantes, seus resíduos e embalagens; 5) lâmpadas fl uorescentes, e vapor de sódio e mercúrios e de luz mista; 6) produtos eletroeletrônicos e seus componentes; 7) embalagens em geral (plásticas, metálicas ou de vidro) (MMA, 2014a). 
referida lei, prevê também como instrumentos os sistemas de informações sobre resíduos sólidos e meio ambiente, como Sistema Nacional de Informações sobre a Gestão dos Resíduos Sólidos (Sinir) e Sistema Nacional de Informação sobre Meio Ambiente (Sinima).

A institucionalização da compostagem como destinação final ambientalmente adequada obrigatória é outro quesito relevante decorrente da aprovação da Lei. Com a PNRS torna-se responsabilidade do titular dos serviços públicos de limpeza urbana e de manejo de resíduos sólidos "implantar sistema de compostagem para resíduos sólidos orgânicos e articular com os agentes econômicos e sociais formas de utilização do composto produzido" (BRASIL, 2010a).

No que tange ao contexto histórico, a primeira iniciativa, com referência ao que viria a ser a futura Política Nacional de Resíduos Sólidos, data do ano de 1989 e decorre do Projeto de Lei (n $\left.{ }^{\circ} 354\right)$ do Senado Federal, que apresentou questões sobre resíduos de serviços de saúde, como seu acondicionamento, sua coleta, seu tratamento, transporte e sua destinação final. A tramitação deste Projeto de Lei resultou, em 1991, num novo documento (Projeto de Lei 203) com perfil de processo legislativo.

Depois disso outros projetos de lei, com as mais diversas abordagens, foram incorporados, comissões especiais de estudo foram criadas e inúmeras audiências e reuniões foram realizadas. Em 1999, o Plenário do Conselho Nacional de Meio ambiente (CONAMA) aprovou a Proposição CONAMA 259, que apresentou as Diretrizes Técnicas para a Gestão de Resíduos Sólidos. Porém esta não chegou a ser publicada.

Em 2001, a Comissão Especial da Política Nacional de Resíduos Sólidos foi criada pela Câmara dos Deputados com o objetivo de avaliar o conteúdo do PL 203 e elaborar uma proposta geral em substituição àquela inicial. Nesse mesmo ano, realizou-se o I Congresso Nacional dos Catadores de Materiais Recicláveis, evento em que ocorreu a $1^{\text {a }}$ Marcha Nacional da População de Rua, na qual reuniu cerca de 3000 participantes. 
Dois anos depois, a Presidência da República instituiu o Grupo de Trabalho Interministerial de Saneamento Ambiental, responsável pela discussão de assuntos relacionados à integração das ações de saneamento ambiental na esfera federal. As ações deste Grupo de Trabalho resultaram no Programa de Resíduos Sólidos Urbanos. Em 2005, o CONAMA consolidou e sistematizou o PL 203 e seus apensos e a Câmara dos Deputados instituiu a Comissão Especial da Política Nacional de Resíduos Sólidos, que apresentou, no ano seguinte, um substitutivo para a Política de Resíduos. Vale destacar que "nas edições da Conferência de Meio Ambiente de 2003 e de 2005 houve vários debates e seminários sobre resíduos, com o objetivo de reunir contribuições para a política nacional que vinha sendo desenhada" (INSTITUTO, 2012, p. 19).

O que poderia vir a ser uma política para resíduos sólidos ganhou corpo de fato em 2007, quando o Executivo Federal enviou para o Congresso, o Projeto de Lei 1991, que apresentava uma proposta para Política Nacional de Resíduos Sólidos, compatível com a Política Nacional de Saneamento Básico (Lei no 11.445/2007) e com a Lei dos Consórcios (Lei $\mathrm{n}^{\mathrm{o}}$ 11.795/2008). Também nesse ano, foi criado um grupo de trabalho com o objetivo de viabilizar a resolução dos assuntos relacionados à Política Nacional de Resíduos Sólidos.

Após a realização de diversas audiências públicas, uma minuta do relatório final foi apresentada em junho de 2009, para receber contribuições adicionais. No ano seguinte, o Projeto de Lei nº 203/1991 foi aprovado pela Câmara dos Deputados, em março, e Senado, em julho, até que em 2 de agosto de 2010, o texto aprovado pelo Congresso Nacional foi sancionado pela Presidência da República, sem nenhum veto, como Lei no $12.305 / 2010$, que instituiu a Política Nacional de Resíduos Sólidos. A lei cria o Comitê Interministerial da Política Nacional de Resíduos Sólidos, que é coordenado pelo Ministério do Meio Ambiente e composto por mais doze ministérios, cuja responsabilidade é elaborar e implementar o Plano Nacional de Resíduos Sólidos. 
Apesar dos quase 20 anos de tramitação e de conter detalhes que desagradaram alguns setores, a PNRS é considerada uma lei moderna, especialmente por vir acompanhada de instrumentos inovadores, como a responsabilidade compartilhada e a determinação de contemplar a inclusão social dos catadores. (INSTITUTO, 2012, p. 19).

Como forma de viabilizar sua aplicação, a Política Nacional de Resíduos Sólidos apresenta, em seu artigo oitavo, dezenove instrumentos que partem, basicamente, de incentivos fiscais, financeiros e creditícios como base de apoio para ações voltadas à correta gestão dos resíduos sólidos. Dentre esses instrumentos, destaque para o fortalecimento do Fundo Nacional do Meio Ambiente e do Fundo Nacional de Desenvolvimento Científico e Tecnológico; o incentivo à adoção de consórcios ou de outras formas de cooperação entre os entes federados; o incentivo à criação e ao desenvolvimento de cooperativas, e outras formas de associação de catadores de materiais reutilizáveis e recicláveis, e o desenvolvimento do Plano de Gestão de Resíduos Sólidos, que constitui a base para todo processo de gestão de resíduos em instituições públicas e privadas (MONTAGNA et al., 2012).

\subsubsection{Resíduos sólidos: definição e classificação}

O manejo adequado dos resíduos sólidos ocupa posição de destaque no que se refere à promoção de práticas voltadas para o desenvolvimento sustentável, isso porque "sua geração, descarte e disposição inadequados provocam diversos impactos ambientais, sociais, econômicos e de saúde pública" (GONÇALVES et al., 2010, p. 80). No Brasil, o assunto tem sido amplamente discutido na sociedade, englobando várias outras áreas como saneamento básico, meio ambiente, inserção social e econômica dos processos de triagem e reciclagem dos materiais (PROSAB, 2003). Isso se dá em grande parte pelo fato de que, se manejados adequadamente, este tipo de resíduo adquire valor comercial, podendo ser utilizado em forma de novas matérias-primas ou novos insumos. 
Para efeitos de normatização, a NBR 10.004 define resíduos sólidos como:

Resíduos nos estados sólido e semi-sólido, que resultam de atividades de origem industrial, doméstica, hospitalar, comercial, agrícola, de serviços e de varrição. Ficam incluídos nesta definição os lodos provenientes de sistemas de tratamento de água, aqueles gerados em equipamentos e instalações de controle de poluição, bem como determinados líquidos cujas particularidades tornem inviável o seu lançamento na rede pública de esgotos ou corpos de água, ou exijam para isso soluções técnica e economicamente inviáveis em face à melhor tecnologia disponível. (ABNT, 2004).

Essa definição torna evidente a diversidade e complexidade dos resíduos sólidos. A Política Nacional de Resíduos Sólidos destaca ainda que é preciso diferenciar resíduos de rejeitos. De acordo com a Lei $\mathrm{n}^{\circ}$ 12.305/2010, rejeitos são "resíduos sólidos que, depois de esgotadas todas as possibilidades de tratamento e recuperação por processos tecnológicos disponíveis e economicamente viáveis, não apresentem outra possibilidade que não a disposição final ambientalmente adequada”.

No que refere à classificação, os resíduos sólidos possuem várias denominações, origens diferenciadas e diversas composições. Para diferenciá-los, a legislação brasileira vigente utiliza-se de diversas bases, sendo mais comuns aquelas relacionadas à sua natureza física, composição química, origem e quanto aos riscos potenciais de contaminação do meio ambiente. Em relação à origem, a Política Nacional de Resíduos Sólidos define as seguintes categorias:

I. Resíduos sólidos urbanos: são os resíduos gerados em domicílios e na limpeza urbana;

a) Resíduos domiciliares: são aqueles originários de atividades domésticas em residências urbanas.

b) Resíduos de limpeza urbana: referem-se aos resíduos originários da varrição, limpeza de logradouros e vias públicas e outros serviços de limpeza urbana. 
II. Resíduos de estabelecimentos comerciais e prestadores de serviços: são os resíduos gerados nessas atividades, exceto os decorrentes de limpeza urbana, serviços públicos de saneamento básico, serviços de saúde, construção civil e serviços de transporte;

III. Resíduos dos serviços públicos de saneamento básico: são os gerados nessas atividades, excetuados os resíduos classificados como Resíduos Sólidos Urbanos;

IV. Resíduos industriais: os gerados nos processos produtivos e instalações industriais;

V. Resíduos de serviços de saúde: referem-se aos gerados nos serviços de saúde, conforme definido em regulamento ou em normas estabelecidas pelos órgãos do Sistema Nacional do Meio Ambiente (Sisnama) e do Sistema Nacional de Vigilância Sanitária (SNVS);

VI. Resíduos da construção civil: os gerados nas construções, reformas, reparos e demolições de obras de construção civil, incluídos os resultantes da preparação e escavação de terrenos para obras civis;

VII. Resíduos agrossilvopastoris: são os gerados nas atividades agropecuárias e silviculturais, incluídos os relacionados a insumos utilizados nessas atividades;

VIII. Resíduos de serviços de transportes: os originários de portos, aeroportos, terminais alfandegários, rodoviários e ferroviários e passagens de fronteira;

IX. Resíduos de mineração: referem-se aos gerados na atividade de pesquisa, extração ou beneficiamento de minérios;

A norma ABNT NBR 10.004 classifica os resíduos sólidos de acordo com a sua periculosidade, ou seja, a definição é estabelecida a partir da característica do resíduo em função de suas propriedades físicas, químicas ou infectocontagiosas (ZANTA; FERREIRA, 2003). Tal classificação é realizada a partir da conceituação de grupos em “classes”: 
CLASSE I - Resíduos Perigosos: são assim classificados por apresentarem risco à saúde pública e ao meio ambiente devido às suas características de inflamabilidade, corrosividade, reatividade e patogenicidade. São exemplos desse tipo de resíduos: baterias, pilhas, óleo usado, restos de tintas e pigmentos, resíduos de serviços de saúde, etc.

CLASSE II - Resíduos Não Perigosos: são aqueles que não se enquadram na Classe I, subdividindo-se em "não inertes" e "inertes". Os primeiros formam o subgrupo Classe II A e referem-se àqueles resíduos que não apresentam riscos à saúde pública e ao meio ambiente, como por exemplo, lodos de estação de tratamento de água e esgoto, papel, restos de alimentos etc. Já os “inertes” pertencem ao subgrupo Classe II B e relacionam-se àqueles que não solubilizam quando um de seus componentes entra em contato com a água. São exemplos desse subgrupo os tijolos, vidros, certos plásticos, borrachas, etc. (MONTAGNA et al., 2012).

Os resíduos sólidos também podem ser classificados em relação à sua composição química e natureza física. No que se refere à composição química, os resíduos são divididos entre orgânicos, que engloba restos de substâncias de origem animal ou vegetal, e inorgânicos, grupo este que compreende os resíduos que não têm origem biológica. Já em relação à natureza física, os resíduos sólidos dividem-se entre resíduos secos, que são os materiais recicláveis, e úmidos, que são os resíduos orgânicos e rejeitos (MONTAGNA et al., 2012).

\subsubsection{Situação dos resíduos sólidos no Brasil}

No Brasil, o problema dos resíduos sólidos está diretamente relacionado ao modelo de desenvolvimento urbano-industrial, isso porque o desenvolvimento de infraestrutura e de serviços urbanos não acompanhou o crescimento das cidades brasileiras. "A economia do País cresceu sem que houvesse, paralelamente, um aumento da capacidade de gestão dos 
problemas acarretados pelo aumento acelerado da concentração humana nas cidades" (MMA, 2011, p. 11). Nesse cenário, a questão referente aos resíduos sólidos por muito tempo fora deixado em segundo plano. O Plano Nacional de Saneamento (Planasa), elaborado na década de 1970, dava atenção especial à ampliação dos serviços de abastecimento de água e de coleta de esgoto em detrimento de investimentos em resíduos sólidos (MONTAGNA et al., 2012).

Apenas na década seguinte, em 1980, a temática do lixo foi integrada aos debates sobre saneamento em decorrência da proliferação de lixões como consequência do intenso processo de urbanização vivido pelo país nesse período. A criação do Programa de Saneamento para População de Baixa Renda (Prosanear), pelo Banco Nacional de Habitação (BNH), em 1985, apresentou uma visão integrada do saneamento, a partir do financiamento de ações conjuntas envolvendo água, esgoto, drenagem urbana e resíduos sólidos. Em 1988, o Prosanear contava com recursos do Banco Mundial, da ordem de US\$ 80 milhões, e promovia o uso de tecnologias de baixo custo e a participação das comunidades beneficiárias (HESPANHOL, 1999).

Com a redemocratização e a Constituição de 1988, ocorreu uma reformulação institucional e legislativa que promoveu um processo de transformação, para melhor, da vida nas cidades: o Estatuto da Cidade, aprovado em 2001, que estabeleceu novos marcos regulatórios; e regulamentos de gestão urbana como as leis de saneamento básico e de resíduos sólidos. (MMA, 2011, p. 11).

Mas foi apenas a partir de 2010 que a questão dos resíduos sólidos no Brasil se consolidou com o estabelecimento legal de metas e prazos específicos. A Política Nacional de Resíduos Sólidos definiu o prazo de até 2 de agosto de 2014 para que a destinação final ambientalmente adequada de resíduos e rejeitos estivesse implantada no País. Porém, o que se observa é que cinco anos após a aprovação da Lei, a gestão de resíduos sólidos ainda constitui um cenário frágil e deficitário. 
Neste panorama, estudos indicam que a destinação final compreende o ponto mais deficiente no sistema de gestão de resíduos brasileiro. Segundo dados da Associação Brasileira de Empresas de Limpeza Pública e Resíduos Especiais (Abrelpe), em 2013, o uso de locais impróprios para a destinação do lixo foi registrado em $60 \%$ dos municípios brasileiros. Ainda de acordo com a Abrelpe, neste mesmo ano, do total de resíduos gerados pelos 404 municípios pesquisados, 41,7\% foram depositados em lixões e aterros controlados, que pouco se diferenciam dos lixões, em termos de impacto ambiental.

2.3.3 Principais legislações e normatizações ambientais brasileiras aplicadas à resíduos

A Legislação ambiental brasileira que lida com a gestão de resíduos sólidos abarca um verdadeiro arcabouço de leis, decretos e normas federais, estaduais e municipais. Criada em 1981, a Lei da Política Nacional do Meio Ambiente (Lei nº 6.938/1981) constituiu "o marco inicial das ações para conservação ambiental e incorporação do tema nas atividades de diversos setores da sociedade" (MMA, 2009, p. 11). Esta Lei é responsável pelo estabelecimento de padrões que possibilitem o desenvolvimento sustentável, por meio de mecanismos e instrumentos capazes de conferir ao meio ambiente uma maior proteção.

Outro marco importante para a conservação ambiental no Brasil foi a publicação, em fevereiro de 1998, da Lei de Crimes Ambientais $n^{\circ}$ 9.605, que instituiu sanções penais e administrativas derivadas de condutas e atividades degradação do meio ambiente. No ano seguinte, a Lei 9.795/1999 estabeleceu a Educação Ambiental como componente essencial e permanente da educação nacional, de forma articulada, em todos os níveis e modalidades do processo educativo, em caráter formal e não-formal, sendo um direito de todos (MMA, 2009). 
Em 2007, foi sancionada a Lei $\mathrm{n}^{\mathbf{0}} 11.445$, que definiu as diretrizes nacionais para o saneamento básico e para a política federal de saneamento básico. Por meio desta normativa, coube à União a elaboração do Plano Nacional de Saneamento Básico (PNSB), abrangendo o abastecimento de água potável, o esgotamento sanitário, a limpeza urbana, o manejo de resíduos sólidos e o manejo de águas pluviais urbanas, além de outras ações de saneamento básico de interesse para a melhoria da salubridade ambiental.

Essas leis se interrelacionam no sentido de que uma cita a outra em seu texto, ou a usa como instrumento legal para aplicação do seu objetivo. Determinados elementos da questão de resíduos sólidos, por exemplo, são tratados em cada uma das leis acima citadas, sendo abordados de forma mais ampla e detalhada na lei 12.305/10. (MONTAGNA et al., 2012, p. 16).

O Programa de Pesquisa em Saneamento Básico (2003) destaca ainda outras legislações federais de interesse:

- Resolução Conama $n^{\circ}$ 005, de 31 de março de 1993 - Dispõe sobre o tratamento de resíduos gerados em estabelecimentos de saúde, portos e aeroportos e terminais ferroviários e rodoviários;

- Lei ordinária n 787, de 1997 - Dispõe sobre o Programa de Prevenção de Contaminação por Resíduos Tóxicos, a ser promovido por empresas fabricantes de lâmpadas fluorescentes, de vapor de mercúrio, vapor de sódio e luz mista e dá outras providências;

- Resolução Conama n 237, de 19 de dezembro de 1997 - Estabelece norma geral sobre licenciamento ambiental, competências, listas de atividades sujeitas a licenciamento, etc.;

- Resolução Conama n 257, de 30 de junho de 1999 - Define critérios de gerenciamento para destinação final ambientalmente adequada de pilhas e baterias;

- Resolução Conama no 283/2001 - Dispõe sobre o tratamento e a destinação final dos resíduos dos serviços de saúde, que visa aprimorar, atualizar e complementar os 
procedimentos contidos na Resolução Conama $n^{\circ}$ 05/93 e estender as exigências às demais atividades que geram resíduos de serviços de saúde.

No âmbito da normatização técnica da Associação Brasileira de Normas Técnicas $(\mathrm{ABNT})$ cabe destacar:

- NBR 7039, de 1987 - Pilhas e acumuladores elétricos - Terminologia;

- NBR 7500, de 1994 - Símbolos de riscos e manuseio para o transporte e armazenamento de materiais;

- NBR 7501, de 1989 - Transporte de produtos perigosos - Terminologia;

- NBR 9190, de 1993 - Sacos plásticos - Classificação;

- NBR 9191, de 1993 - Sacos plásticos - Especificação;

- NBR 10004, de 1987 - Resíduos sólidos - Classificação;

- NBR 10006 - Solubilização de resíduos;

- NBR 10007 - Amostragem de resíduos;

- NBR 11174, de 1990 - Armazenamento de resíduos classe II, não-inertes, e III, inertes Procedimentos.

- NBR 12245, de 1992 - Armazenamento de resíduos sólidos perigosos - Procedimentos;

- NBR 13055, de 1993 - Sacos plásticos para acondicionamento de lixo - Determinação da capacidade volumétrica;

- NBR 13221, de 1994 - Transporte de resíduos - Procedimento;

- NBR 13463, de 1995 - Coleta de resíduos sólidos - Classificação.

Em suma, a legislação ambiental brasileira, um dos principais instrumentos e promoção da sustentabilidade ecológica, prevê a manutenção e conservação do meio ambiente 
ao mesmo tempo em que contempla a necessidade de adoção de uma nova ética social, buscando explorar a dimensão econômica de forma racional e adequada, visando a manutenção do equilíbrio ecológico, garantia da saúde, qualidade de vida e bem-estar econômico, social e ambiental do país.

\subsection{Plano de Gerenciamento de Resíduos Sólidos}

Definidos nos capítulos iniciais como um dos instrumentos da Política Nacional de Resíduos Sólidos, os Planos de Gerenciamento de Resíduos Sólidos (PGRS) são de suma importância para a redução de custos e riscos associados à gestão de resíduos. Além disso, um PGRS representa segurança legal, operacional, ocupacional e proteção ao meio ambiente (COLLOVINI et al., 2014).

\footnotetext{
O objetivo do PGRS é contribuir para a redução da geração de resíduos sólidos, orientando o correto acondicionamento, armazenamento, coleta, transporte, tratamento e destinação final. O PGRS deve apontar e descrever ações relativas ao manejo de resíduos sólidos e conter a estratégia geral dos responsáveis pela geração dos resíduos para proteger a saúde humana e o meio ambiente. (CURITIBA, 2011).
}

Cabe destacar, entretanto, que embora sejam usados como sinônimo para designarem o mesmo processo em diversos contextos, os termos gestão e gerenciamento referem-se a situações distintas quando se trata de resíduos sólidos. As teorias da Administração Pública definem o conceito de gestão como "ato ou efeito de gerir, administrar, gerenciar; administração, gerência" (DENHARDT, 2012, p. 344). Já o termo gerenciamento, que é proveniente da Escola de Administração, está ligado às noções de planejamento e controle e assume uma conotação de prevenção e correção de problemas quando associado à área de resíduos sólidos (LOPES, 2003). Em uma visão conceitual mais ampla, pode-se afirmar que a gestão de resíduos sólidos refere-se a todas as normas e leis relacionadas a este processo, 
enquanto o gerenciamento relaciona-se às operações que envolvem os resíduos, como coleta, transporte, tratamento, disposição final, entre outras (LOPES, 2003).

A própria Política Nacional de Resíduos Sólidos traz em seu texto um conceito para cada um dos termos. Segundo o artigo $3^{\circ}$, da Lei $\mathrm{n}^{\mathrm{o}} 12.305 / 2010$, a gestão integrada de resíduos sólidos compreende o "conjunto de ações voltadas para a busca de soluções para os resíduos sólidos, de forma a considerar as dimensões política, econômica, ambiental, cultural e social, com controle social e sob a premissa do desenvolvimento sustentável" (BRASIL, 2010a). Já gerenciamento de resíduos sólidos, de acordo com mesmo artigo, corresponde:

Ao conjunto de ações exercidas, direta ou indiretamente, nas etapas de coleta, transporte, transbordo, tratamento e destinação final ambientalmente adequada dos resíduos sólidos e disposição final ambientalmente adequada dos rejeitos, de acordo com plano municipal de gestão integrada de resíduos sólidos ou com plano de gerenciamento de resíduos sólidos, exigidos na forma desta Lei. (BRASIL, 2010a).

Dessa forma, pode-se entender a gestão de resíduos sólidos como o processo de interrelação entre aspectos administrativos, financeiros, legais, de planejamento, de engenharia e de educação presentes no processo de gerenciamento (PENELUC; SILVA, 2008). Enquanto este, constitui um conjunto de procedimentos de gestão, planejados e implementados com o objetivo de minimizar a produção de resíduos e proporcionar aos resíduos gerados, a adequada coleta, armazenamento, tratamento, transporte e destino final adequado, visando à preservação da saúde pública e a qualidade do meio ambiente. "Dentro do gerenciamento, destacam-se ainda as questões de responsabilidade e o envolvimento dos setores da sociedade em relação à geração dos resíduos" (LOPES, 2003, p. 30).

A implantação de um PGRS abarca a utilização de outros recursos também previstos pela PNRS, como coleta seletiva, implementação da corresponsabilidade pelo ciclo de vida dos produtos, sistema de logística reversa e educação ambiental. Faz-se importante ressaltar também que os planos devem respeitar o conteúdo mínimo e a ordem de prioridade previstos 
em lei (não geração, redução, reutilização, reciclagem, tratamento e destinação final, conforme apresentadas no fluxograma da Figura 2), bem como as resoluções referentes ao Conama, Anvisa, ABNT, entre outros apresentados no item 2.3.3.

Figura 2 - Etapas para elaboração do PGRS

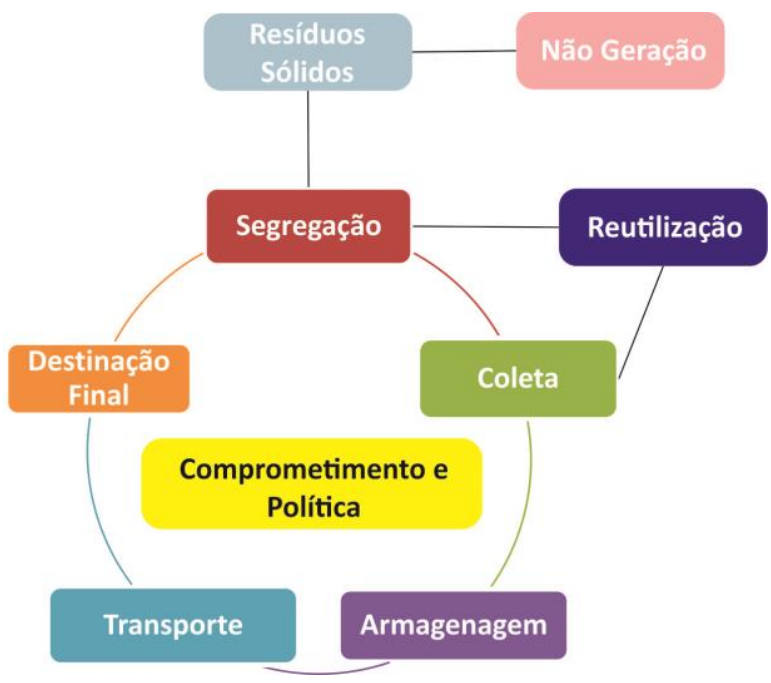

Fonte: Adaptado MMA (2014b).

Com base nas etapas dispostas na Figura 1 e considerando o conteúdo mínimo apresentado na Lei ${ }^{\circ}$ 12.305/2010 o PGRS deve contemplar as seguintes informações:

I - descrição do empreendimento ou atividade;

II - diagnóstico dos resíduos sólidos gerados ou administrados, contendo a origem, o volume e a caracterização dos resíduos, incluindo os passivos ambientais a eles relacionados;

III - observadas as normas estabelecidas pelos órgãos do Sistema Nacional do Meio Ambiente (Sisnama), do Sistema Nacional de Vigilância Sanitária (SNVS) e do Sistema Unificado de Atenção à Sanidade Agropecuária (Suasa) e, se houver, o plano municipal de gestão integrada de resíduos sólidos:

a) explicitação dos responsáveis por cada etapa do gerenciamento de resíduos sólidos; 
b) definição dos procedimentos operacionais relativos às etapas do gerenciamento de resíduos sólidos sob responsabilidade do gerador;

IV - identificação das soluções consorciadas ou compartilhadas com outros geradores;

V - ações preventivas e corretivas a serem executadas em situações de gerenciamento incorreto ou acidentes;

VI - metas e procedimentos relacionados à minimização da geração de resíduos sólidos e, observadas as normas estabelecidas pelos órgãos do Sisnama, do SNVS e do Suasa, à reutilização e reciclagem;

VII - se couber, ações relativas à responsabilidade compartilhada pelo ciclo de vida dos produtos, na forma do art. 31 ;

VIII - medidas saneadoras dos passivos ambientais relacionados aos resíduos sólidos; IX - periodicidade de sua revisão, observado, se couber, o prazo de vigência da respectiva licença de operação a cargo dos órgãos do Sisnama.

A Lei prevê também, em seu artigo 22, que as ações propostas pelo PGRS devem ser monitoradas por responsável técnico devidamente habilitado, que também será responsável pela elaboração, implementação e operacionalização de todas as etapas do plano, incluindo o controle da disposição final ambientalmente adequada dos rejeitos. O Ministério do Meio Ambiente, em seu manual de orientações para elaboração de Planos de Resíduos Sólidos (MMA, 2012), deixa claro que mecanismos de monitoramento e controle devem compor as estratégias presentes no planejamento das ações propostas pelo PGRS.

Assim, considerando que as agendas dos órgãos públicos devam promover a sustentabilidade de acordo com o quadro legal existente, torna-se evidente observar a importância de que instituições públicas elaborem seus planos de gerenciamento de resíduos sólidos e de que sua elaboração seja fruto do comprometimento da alta administração 
institucional. "Esse compromisso é condição essencial para uma efetiva política de responsabilidade socioambiental que inclua a gestão de resíduos sólidos como uma questão fundamental” (MMA, 2014a, p. 41). Além disso, os órgãos e entidades públicas devem elaborar os seus planos de gerenciamento para:

dar o exemplo e atender às expectativas da sociedade; promover maior controle da destinação dos resíduos pelo poder público; dar continuidade e aperfeiçoar o disposto no Decreto $\mathrm{n}^{\mathrm{o}} 5.940 / 06$ que trata da coleta seletiva solidária; reduzir os custos operacionais por meio do reaproveitamento de materiais; aperfeiçoar a gestão dos resíduos sólidos; reduzir os impactos ambientais e a desigualdade social. (MMA, 2014a, p. 14).

O Plano Nacional de Resíduos Sólidos (PNRS), que está em processo de construção e encontra-se em versão preliminar desde 2012, representa o primeiro passo do planejamento da gestão de resíduos sólidos no país. O documento mantém relação com os Planos Nacionais de Mudanças do Clima (PNMC), de Recursos Hídricos (PNRH), de Saneamento Básico (Plansab) e de Produção e Consumo Sustentável (PPCS) e expõem conceitos e propostas para diversos setores da economia compatibilizando crescimento econômico e preservação ambiental com desenvolvimento sustentável, além de apresentar metas para diferentes cenários, programas, projetos e ações correspondentes. Sua vigência está prevista por prazo indeterminado e horizonte de 20 anos, com atualização a cada quatro anos compatibilizadas com os Planos Plurianuais de Investimentos (PPA) do Governo Federal.

O PNRS está constituído por sete partes, iniciando-se pelo diagnóstico sobre a situação dos resíduos sólidos no Brasil, elaborado pelo Instituto de Pesquisa Econômica Aplicada (IPEA) e apresentado no capítulo 1. O diagnóstico de resíduos sólidos urbanos (RSU) é analisado sob três universos: o primeiro considera o país como unidade de análise, no segundo trabalha-se com as cinco regiões brasileiras e o último considera o porte dos municípios, definido em função da população. As informações contidas nesta parte do Plano foram estruturadas seguindo o ciclo dos resíduos: geração, coleta (tradicional e seletiva), 
tratamento e disposição final, e o fluxo de cada um dos materiais recicláveis. Por fim são apresentadas algumas conclusões e recomendações (MMA, 2012).

O Capítulo 2 trata dos Cenários Macroeconômicos e Institucionais em consonância com o Plano Nacional de Saneamento Básico (Plansab). De acordo com o documento, o Cenário 1, indica um futuro possível e desejável, constituindo o ambiente para o planejamento e suas diretrizes, estratégias, metas, investimentos e procedimentos de caráter políticoinstitucional necessários para alcançar o planejado. Nesse Cenário, o Brasil é projetado, em 2030, como um país saudável e sustentável, com elevadas taxas de crescimento econômico e de investimentos do setor público e privado, expressiva melhoria dos indicadores sociais, redução das desigualdades urbanas e regionais e melhoria do meio ambiente, servindo como modelo de desenvolvimento com consumo sustentável (MONTAGNA et al., 2012). Os Cenários 2 e 3 são descritos e mantidos como referências para o planejamento das ações propostas pelo Plano. Caso o monitoramento destes dois cenários identifique significativos desvios do Cenário 1 em direção à situações alternativas, correções devem ser implementadas nas premissas e proposições do Plano, incluindo metas e necessidades de investimentos.

O capítulo 3 expõem as particularidades da educação ambiental dentro do PNRS e como seus desenvolvimento e resultados coadunam para o alcance das metas. No capítulo 4 são abordas as principais Diretrizes e Estratégias relacionadas aos resíduos sólidos, apresentando as linhas norteadoras por grandes temas e os meios, pelos quais as respectivas ações serão implementadas. Consta, portanto, neste capítulo as ações e os programas a serem delineados com vistas ao cumprimento das metas. As Diretrizes e Estratégias estabelecidas buscam garantir o atendimento aos prazos legais, fortalecimento de políticas públicas, o incremento dos percentuais de destinação, tratamento dos resíduos sólidos e disposição final ambientalmente adequada dos rejeitos, a inserção social dos catadores de materiais reutilizáveis e recicláveis, a melhoria da gestão e do gerenciamento dos resíduos sólidos como 
um todo e o fortalecimento do setor de resíduos sólidos per si e as interfaces com os demais setores da economia brasileira (MMA, 2011).

As metas de curto, médio e longo prazo para resíduos sólidos, que se espera alcançar no horizonte temporal do Plano Nacional de Resíduos Sólidos são apresentadas no capítulo 5. As metas foram projetadas tendo como base os cenários descritos no Capítulo 2 e como suas execuções estão relacionadas também ao envolvimento e atuação dos três níveis de governo, da sociedade e da iniciativa privada, foram definidos três Planos de Metas: Proposta 1, com viés favorável, Proposta 2, com viés intermediário e Proposta 3, com viés pessimista. Vale destacar que para o cumprimento das metas previstas no plano favorável é necessário disponibilidade de recursos com suporte dos três níveis de governo e da iniciativa privada, além de capacitação institucional, capacidade institucional e de endividamento.

Já o capítulo 6 prioriza os programas e ações que contribuirão para a execução das tarefas necessárias para o alcance das metas, enquanto no capítulo 7 são apresentadas informações referentes à transparência da gestão da Política Nacional de Resíduos Sólidos por meio do acompanhamento da implementação do PNRS pela sociedade. Por fim, para o processo de implementação, monitoramento da implementação e revisão do Plano Nacional de Resíduos Sólidos está previsto o envolvimento entre os entes federados (União, Estado e Municípios), aliado à participação dos diversos setores sociais, à mobilização da sociedade e controle social.

A existência de um plano nacional é importante não só pelo direcionamento de ações e cumprimento de prazos em favor da gestão de resíduos sólidos no país, mas exerce também forte papel como norteador para o desenvolvimento dos outros planos de responsabilidade pública, influenciando, inclusive os planos de gerenciamento de resíduos sólidos exigidos de alguns dos geradores (MMA, 2011). Além disso, o PNRS apresenta informações quantitativas e qualitativas importantes que podem servir também de referência para a elaboração dos 
outros planos, como, por exemplo, dados sobre experiências de compostagem no Brasil, a logística reversa com embalagens de agrotóxicos e a posição do Brasil como referência mundial neste quesito e informações sobre os resíduos da construção civil que podem representar de 50 a 70\% da massa de resíduos sólidos urbanos (MMA, 2012). 


\section{METODOLOGIA}

Em função de se atender o objetivo geral proposto por este projeto, a pesquisa se caracterizou como exploratória e investigativa, com estudo de caso. Em um primeiro momento foi realizada pesquisa bibliográfica com vistas a delimitar o marco de referência teórico do projeto. Nessa perspectiva, o esforço de revisão de literatura foi dedicado à definição das categorias de análise "gestão pública", "avaliação e monitoramento" e "responsabilidade socioambiental". Nesta etapa, a pesquisa caracteriza-se, quanto aos fins, como exploratória. Esta técnica "é realizada em área na qual há pouco conhecimento acumulado e sistematizado" (VERGARA, 1998, p. 45). O objetivo desse tipo de estudo é procurar padrões, ideias ou hipóteses. "Embora o planejamento da pesquisa exploratória seja bastante flexível, na maioria dos casos assume a forma de pesquisa bibliográfica ou de estudo de caso" (GIL, 2008).

A pesquisa assume também características de estudo de caso, por se tratar de uma abordagem metodológica de investigação que visa compreender, explorar ou descrever acontecimentos e contextos complexos, nos quais estão simultaneamente envolvidos diversos fatores (ARAÚJO et al., 2008). Referência na área, Robert Yin (2001) define esta ferramenta como "uma investigação empírica que investiga um fenômeno contemporâneo dentro de seu contexto da vida real, especialmente quando os limites entre o fenômeno e o contexto não estão claramente definidos" (YIN, 2001, p. 32). Foram realizadas também observações, entrevistas informais e aplicação de questionários com os alunos e servidores do IF Goiano Campus Trindade, além de registros visuais por meio de fotos.

A segunda etapa metodológica compreende o desenvolvimento do Plano de Gerenciamento de Resíduos Sólidos para o IF Goiano - Campus Trindade, cuja elaboração baseou-se no conteúdo mínimo de um PGRS, previsto na Lei n ${ }^{\circ}$ 12.305/2010 (artigo 15), e 
também na Política de Resíduos Sólidos da Universidade de São Paulo (USP, 2013). Segue o conteúdo mínimo do PGRS a ser elaborado:

I - descrição do empreendimento ou atividade;

II - sensibilização da comunidade envolvida;

III - diagnóstico dos resíduos sólidos gerados ou administrados, contendo a origem, o volume e a caracterização dos resíduos, incluindo os passivos ambientais a eles relacionados;

IV - observadas as normas estabelecidas pelos órgãos do Sisnama, do SNVS e do Suasa e, se houver, o plano municipal de gestão integrada de resíduos sólidos:

a) explicitação dos responsáveis por cada etapa do gerenciamento de resíduos sólidos;

b) definição dos procedimentos operacionais relativos às etapas do gerenciamento de resíduos sólidos sob a responsabilidade do gerador;

V - identificação das soluções consorciadas ou compartilhadas com outros geradores;

VI - ações preventivas e corretivas a serem executadas em situações de gerenciamento incorreto ou acidentes;

VII - metas e procedimentos relacionados à minimização da geração de resíduos sólidos e, observadas as normas estabelecidas pelos órgãos do Sisnama, do SNVS e do Suasa, à reutilização e reciclagem;

VIII - se couber, ações relativas à responsabilidade compartilhada pelo ciclo de vida dos produtos, na forma do art. 31 ;

IX - medidas saneadoras dos passivos ambientais relacionados aos resíduos sólidos; $\mathrm{X}$ - periodicidade de sua revisão, observado, se couber, o prazo de vigência da respectiva licença de operação a cargo dos órgãos do Sisnama. 
Também foram realizadas como referência para consecução desta metodologia pesquisas desenvolvidas na área por universidades como Pontifícia Universidade Católica do Rio de Janeiro (PUC - RJ), Universidade Federal do Pará (UFPA), Universidade Federal de Santa Catarina (UFSC), Universidade Federal do Pará (UFPA), Universidade Tecnológica Federal do Paraná (UFTP), Universidade Federal de Sergipe (UFS), Universidade Estadual da Paraíba (UEPB), Universidade Fundação Mineira de Educação e Cultura (Fumec) e também dos Institutos Federais do Paraná (IFPR) e de Alagoas (IFAL). Estes trabalhos também serão utilizados para consultas posteriores durante o desenvolvimento da dissertação.

\subsection{Unidade de Análise}

O Campus Trindade do Instituto Federal Goiano (IF Goiano) está situado no município de Trindade, região metropolitana de Goiânia (distante 27 km da capital), onde se localiza a reitoria da Instituição. Cabe destacar que a proximidade com o órgão gestor central do Instituto e a característica urbana da unidade influenciaram de forma decisiva para a escolha da unidade como modelo para desenvolvimento deste PGRS, uma vez que as ações já existentes na Instituição foram articuladas para atender os campi já em funcionamento, que possuem características mais agrícolas e localização em zonas rurais.

Fruto da reinstitucionalização e expansão ${ }^{3}$ da Rede Federal de Educação Profissional e Tecnológica (EPT), o Instituto Federal Goiano, juntamente com outras 37 instituições, foi criado a partir da Lei $\mathrm{n}^{\mathrm{o}} 11.892$, de 29 de dezembro de 2008, que transformou os antigos Centros Federais de Educação Tecnológica (Cefets), Unidades Descentralizadas de Ensino (Uneds), Escolas Agrotécnicas, Escolas Técnicas Federais e escolas vinculadas a universidades em Institutos Federais de Educação, Ciência e Tecnologia. Também faz parte

\footnotetext{
Durante o Governo Dilma (2010-2014) foi promovido Plano de Expansão que contemplou a criação de quatro universidades federais, abertura de 47 campi universitários e 208 unidades dos institutos federais de educação, ciência e tecnologia, espalhados em todo o país.
} 
dessa Rede instituições que não aderiram aos Institutos Federais, mas que também oferecem educação profissional em todos os níveis, sendo dois Cefets, 25 escolas vinculadas a Universidades, o Colégio Pedro II e uma Universidade Tecnológica.

Além de cursos técnicos de nível médio e qualificação profissional de curta duração, os Institutos Federais oferecem cursos de graduação e pós-graduação (mestrado e doutorado), equiparando-se às universidades federais quanto à certificação, regulação, avaliação e supervisão das instituições e dos cursos de educação superior (BRASIL, 2008). O art. $2^{\circ}$ da Lei de criação dos Institutos Federais os define como

instituições de educação superior, básica e profissional, pluricurriculares e multicampi, especializados na oferta de educação profissional e tecnológica nas diferentes modalidades de ensino, com base na conjugação de conhecimentos técnicos e tecnológicos com as suas práticas pedagógicas. (BRASIL, 2008).

O Estado de Goiás foi contemplado com dois Institutos: O Instituto Federal Goiano (IF Goiano) e o de Goiás (IFG). O IF Goiano integrou os antigos Centros Federais de Educação Tecnológica (Cefets) de Rio Verde, de Urutaí e sua respectiva Unidade de Ensino Descentralizada de Morrinhos, mais a Escola Agrotécnica Federal de Ceres (EAFCE) - todos provenientes de antigas escolas agrícolas. Como órgão de administração central, o IF Goiano tem uma Reitoria instalada em Goiânia, capital do Estado. Em 2010, foi inaugurado o Campus Iporá e, em 2011, com uma nova expansão da Rede Federal, a Instituição foi contemplada com três novos campi nas cidades de Trindade, Campos Belos e Posse, nestas duas últimas ainda em fase de implantação. Já em 2014, foram iniciadas atividades em quatro campi avançados ${ }^{4}$, nos municípios de Catalão, Cristalina, Hidrolândia e Ipameri.

O Campus Trindade está construído em uma área de 43 mil metros quadrados, na zona urbana da cidade. Sua estrutura contempla um auditório para 200 pessoas, uma biblioteca, seis

\footnotetext{
$4 \quad$ Portaria $\mathrm{n}^{\mathrm{o}}$ 1.291, de 30 de dezembro de 2013, define campus avançado como estruturas vinculadas “administrativamente a um campus ou, em caráter excepcional, à Reitoria, e destinado ao desenvolvimento da profissional por meio de atividades de ensino e extensão circunscritas a áreas temáticas ou especializadas, prioritariamente por meio da oferta de cursos técnicos e de cursos de formação inicial e continuada".
} 
laboratórios profissionais para atividades práticas dos cursos técnicos, quatro laboratórios específicos de informática, química, física e biologia, sendo um para cada área, 12 salas de aula e dependências administrativas, compostas por: sala de professores, secretaria, gabinete, com uma sala para a chefia de gabinete e outra para a direção-geral, gerência de ensino e gerência administrativa.

As atividades na unidade tiveram início no primeiro semestre de 2015, com a oferta dos cursos técnicos em Informática para Internet, Eletrotécnica, Edificações, e Automação Industrial. Todos na modalidade Integrada ao Ensino Médio, ou seja, o estudante cursa o ensino médio e técnico ao mesmo tempo. Por ser uma unidade urbana, os cursos previstos para este campus estão voltados, preferencialmente, para as áreas de Indústria e Serviços. A expectativa é que, em 2018, a unidade ofereça graduações em Engenharias Civil, Elétrica e Mecatrônica e Ciências da Computação. Fato este que corrobora com a necessidade de se pensar um PGRS diferenciado do que vem sendo trabalhado na Instituição.

No que diz respeito ao quantitativo de pessoas na unidade, segundo informações da Gerência de Administração e Planejamento, em 2015, o quadro administrativo da Instituição era composto por 65 funcionários, dentre servidores docentes, técnico-administrativos e terceirizados. Já o total de alunos neste período era composto por 287 estudantes. Cabe ressaltar que também nesta data, este campus era responsável pela oferta de cursos na modalidade de Educação à Distância (EaD), atendendo a mais de 70 municípios em todo o estado de Goiás e somando mais de 15 mil alunos. Parte do curso exige aulas presenciais, que são ministradas nos Polos de $\mathrm{EaD}$, locais oriundos de parcerias firmadas entre o Instituição e prefeituras ou Estado. Por isso e também pela dificuldade de acesso devido ao grande número e extensa distância entre elas, essas unidades não foram incluídas neste PGRS. 


\subsection{Estudo de Caso e Análise dos Dados}

Neste tópico serão expostas as etapas metodológicas utilizadas para o estudo de caso em questão. Os dados serão analisados com o objetivo de se conhecer a estrutura de gestão de resíduos sólidos da unidade, os níveis de consciência ambiental e consumo consciente do seu público e caracterização de resíduos sólidos gerados no campus.

3.2.1 Estrutura de gestão dos resíduos sólidos no IF Goiano - Campus Trindade

Buscou-se, inicialmente, conhecer a realidade estudada a partir da aplicação de questionário direcionado ao reitor e pró-reitores do Instituto, e diretor-geral, docentes, técnicos administrativos e terceirizados do Campus Trindade. Os formulários foram aplicados no período de setembro à novembro de 2015. As informações obtidas por meio deste instrumento possibilitou o conhecimento sistemático da realidade estudada para elaborar ações a partir das particularidades apresentadas.

O questionário (Anexo A - Questionário 1) é composto por 29 questões, divididas em três dimensões: demográfica e funcional, sensibilização e gerenciamento e manejo do resíduo sólido, que aborda questões referentes à geração, coleta, acondicionamento, transporte interno, tratamento, armazenamento, coleta e transporte externos, disposição final e monitoramento. Foi desenvolvido, principalmente, com referência no PGRS da Pontifícia Universidade Católica do Rio de Janeiro (GOMES, 2012) e na cartilha Plano de Gerenciamento de Resíduos Sólidos - Instrumento de Responsabilidade Socioambiental na Administração Pública, do Ministério do Meio Ambiente (2014a). Os dados foram analisados por meio de Estatística Descritiva, via cálculo de frequência das respostas, através do 
programa Statistical Package for the Social Sciences (SPSS). Este método possibilita a redução de dados, viabilizando a leitura rápida das características apresentadas.

Concomitante à aplicação deste instrumento, realizou-se também visitas in loco com o objetivo de observar as potenciais atividades relacionadas à geração de resíduos sólidos bem como identificar os principais pontos onde elas acontecem no Campus Trindade. Nesta etapa foi necessário coletar informações no de Núcleo de Elaboração e Gerenciamento de Projetos de Engenharia e Arquitetura, da Coordenação-Geral de Desenvolvimento de Infraestrutura do Instituto, localizado na Reitoria, a fim de se obter dados sobre atual infraestrutura da unidade e futuras expansões.

Durante o diagnóstico foi realizado também pesquisa acerca da presença de associações e cooperativas de catadores de materiais recicláveis no município de Trindade, visando atender ao decreto Lei $\mathrm{n}^{\circ} 5.940$ que prevê a implantação da coleta seletiva solidária nos órgãos e entidades da administração pública federal.

3.2.2 Instrumento de mensuração da consciência ambiental e consumo consciente

Além do levantamento das atividades geradoras, buscou-se, também, identificar os níveis de consciência ambiental e de consumo ecologicamente correto da comunidade acadêmica do IF Goiano - Campus Trindade. Ser consciente ecologicamente é assumir responsabilidade nos problemas ambientais e auxiliar na identificação das devidas soluções, sendo a mudança no comportamento das pessoas provenientes da conscientização ambiental (BERTOLINI; POSSAMAI, 2005). Assim, esta mensuração permitirá traçar estratégias mais eficientes para a etapa de sensibilização que se faz necessária a uma implementação eficaz de um PGRS. 
Este índice foi calculado por meio do instrumento proposto por Bertolini e Possamai (2005), que tem por objetivo a busca de informações complementares no que diz respeito à identificação do perfil do consumidor e da postura deste em relação aos produtos ecologicamente corretos (BERTOLINI; POSSAMAI, 2005). Apesar de ser uma ferramenta desenvolvida para o universo mercadológico, seu uso permitiu determinar em que escala servidores e alunos estão dispostos à prática de ações sustentáveis. Para servidores, este instrumento foi aplicado juntamente com o questionário 1 , no período de $1^{\circ}$ de setembro a 20 de outubro, enquanto que, no grupo dos alunos, este formulário foi submetido no prazo de 15 de setembro a 15 de novembro.

O instrumento, cuja elaboração baseou-se em levantamentos bibliográficos sobre conscientização ecológica e consumo ecologicamente correto, consiste em um questionário (Anexo B - Questionário 2) composto por 21 questões, sendo 20 fechadas e uma aberta, e sua construção teve como referência os modelos de Perfil de Qualidade $^{5}$, proposto a partir da adaptação do modelo de Gale, e das Escalas de Likert. $^{6}$

A primeira questão, a única aberta, busca identificar os critérios de compra utilizados pelos consumidores. As perguntas de 2 a 9 visam apresentar o nível de conscientização ecológica dos consumidores, enquanto os itens de 10 a 17 identificam do consumo ecologicamente correto. Ao final do questionário, compreendido pelas questões de 18 a 21, foi elaborado com a intenção de conseguir informações complementares dos entrevistados a fim de garantir maior suporte à avaliação.

As respostas fechadas do questionário são avaliadas por meio de pesos (Quadro 2). No caso das questões de 2 a 17 deve-se multiplicar a quantidade de vezes de cada resposta (a)

\footnotetext{
5 O Perfil da qualidade definido por Gale baseia-se na avaliação que o cliente faz dos atributos de qualidade relevantes, da sua hierarquização e o posicionamento da empresa e dos principais concorrentes em cada atributo (DOMINGUEZ, 2000).

É o modelo mais utilizado e debatido entre os pesquisadores foi desenvolvido por Rensis Likert (1932) para mensurar atitudes no contexto das ciências comportamentais. A escala de verificação de Likert consiste em tomar um construto e desenvolver um conjunto de afirmações relacionadas à sua definição, para as quais os respondentes emitirão seu grau de concordância (SILVA JÚNIOR; COSTA, 2014).
} 
pelos respectivos pontos (b), somando todos os resultados (c) e, por último, dividindo o resultado obtido na operação passada pela quantidade de questões relacionadas à consciência ecológica (d) (BERTOLINI; POSSAMAI, 2005).

Quadro 2 - Alocação de pesos e elaboração do cálculo dos graus de conscientização ecológica e de consumo ecologicamente correto

\begin{tabular}{ccc}
\hline $\begin{array}{c}(\mathbf{a}) \\
\mathbf{N}^{0} \text { Resposta }\end{array}$ & $\begin{array}{c}(\mathbf{b}) \\
\text { Pontuação }\end{array}$ & $\begin{array}{c}(\mathbf{a} \boldsymbol{x} \mathbf{b}) \\
\text { Resultado }\end{array}$ \\
\hline A & 4 & \\
B & 3 & \\
C & 2 & \\
D & 1 & \\
\hline
\end{tabular}

(c) Soma dos resultados

(d) $\mathbf{N}^{0}$ de Questões

$(\mathrm{e}=\mathrm{c} / \mathrm{d})$

Resultado

Fonte: Bertolini e Possamai (2005).

Dos cálculos anteriores resultará um valor (e) - Quadro 2, que servirá para classificar os consumidores. O grau de conscientização ambiental dos respondentes é identificado segundo Quadro 3, enquanto o nível de consumo ecologicamente correto dos consumidores é definido de acordo com o Quadro 4.

Quadro 3 - Grau de conscientização ambiental do consumidor

\begin{tabular}{ll}
\hline CLASSIFICAÇÃO DO CONSUMIDOR & PONTUAÇÃ̃O \\
\hline Consciente em relação ao meio ambiente & 4 a 3,5 \\
Potenciais traços de consciência ambiental & 3,5 a 2,5 \\
Poucos traços de consciência ambiental & 2,5 a 1,5 \\
Não possui consciência ambiental & 1,5 a 1 \\
\hline
\end{tabular}

Fonte: Bertolini e Possamai (2005).

Quadro 4 - Grau de consumo ecologicamente correto dos consumidores

\begin{tabular}{ll}
\hline CLASSIFICAÇÃO DO CONSUMIDOR & PONTUAÇÃ̃O \\
\hline Consumidor ecologicamente correto & 4 a 3,5 \\
Potencial consumidor ecologicamente correto & 3,5 a 2,5 \\
Fraco consumidor ecologicamente correto & 2,5 a 1,5 \\
Consumidor não ecológico & 1,5 a 1 \\
\hline
\end{tabular}

Fonte: Bertolini e Possamai (2005). 
No caso da questão um, a única aberta, o respondente deverá listar os critérios de seleção por ele utilizados durante a compra de produtos, distribuindo 10 pontos de ponderação de importância entre estes critérios listados. Por orientações dos autores, é recomendável que o pesquisador esteja presente durante a aplicação do questionário, para a resolução de possíveis dúvidas dos entrevistados. Este questionário foi aplicado à toda comunidade acadêmica da unidade (alunos, docentes, técnicos administrativos e terceirizados).

Foi possível ainda traçar um perfil dos servidores e alunos do Campus Trindade por meio das informações contidas nos dois questionários. Esses dados foram compilados em um único arquivo e sua análise foi também foi realizada por meio de Estatística Descritiva, com o programa Statistical Package for the Social Sciences (SPSS).

3.3.3 Classificação, caracterização e composição gravimétrica dos Resíduos Sólidos e definição da taxa de geração per capita

O fato de faculdades e universidades poderem ser comparadas a pequenos núcleos urbanos, em decorrência das diversas ações de ensino, pesquisa, extensão e atividades referentes à sua operação por meio de lanchonetes, restaurantes, alojamentos, centros de conveniência, entre outras facilidades (TAUCHEN; BRANDLI, 2006) permite classificar os resíduos por elas gerados, basicamente, como resíduos sólidos urbanos, segundo definição contida na Política Nacional de Resíduos Sólidos. Assim, considerando que os institutos federais são instituições equiparadas às universidades, parte-se do pressuposto de que os resíduos gerados no IF Goiano - Campus Trindade se classificam como urbanos, quanto a origem.

Em relação à periculosidade, a Lei n ${ }^{0}$ 12.305/2010 distingue os resíduos perigosos dos não perigosos. Nesse sentido a classificação será realizada de acordo com a norma técnica NBR 10004:2004, que se baseia na caracterização do resíduo a partir da concentração de 
poluentes em suas matrizes. De acordo com a NBR 10004, os resíduos são classificados em Classe I, para perigosos, e Classe II, para não perigosos, sendo esta última subdividida em dois grupos: A, para não inertes ${ }^{7}, \mathrm{e} \mathrm{B}$, para inertes. ${ }^{8}$

Já a caracterização consiste em uma ferramenta essencial para compreender o comportamento físico dos elementos que compõem os resíduos sólidos, bem como seus fluxos, desde a coleta até o destino final. Além disso, é importante por viabilizar subsídios para dimensionar a quantidade de lixo produzido em cada área, fornecendo dados mais precisos para a elaboração de um modelo de gestão ambientalmente correto e economicamente viável (GOMES, 2012). A caracterização foi realizada durante o período de dez dias úteis, de 9 a 13 e 16 a 20 de novembro de 2015, por meio de catação manual, separação e pesagem dos resíduos sólidos gerados no campus. Assim foi possível identificar a composição gravimétrica de cada grupo de resíduo classificado.

\begin{abstract}
A composição gravimétrica é o percentual de cada componente em relação ao peso total da amostra. Quanto maior a quantidade de um determinado componente, mais as características gerais dos resíduos se assemelharão às características desse componente. Portanto, caracterizar gravimetricamente o resíduo permite adoção de medidas, olhando cada componente e reconhecendo sua participação no todo, avaliando quantitativamente e qualitativamente correlacionando extratos sócioeconômicos e culturais por grupos geradores. (CARVALHO; JESUS; PORTELA, s.d.).
\end{abstract}

Como não existem práticas de segregação de lixo ou coleta seletiva consolidadas na unidade, os resíduos separados serão caracterizados de acordo com a relevância que apresentam em relação a massa total pesada diariamente. Poderão ser apresentados os seguintes materiais: alumínio, papéis - papel e papelão, plásticos - fino e rígido, material

7 São aqueles resíduos que podem ter propriedades, tais como: biodegradabilidade, combustibilidade ou solubilidade em água (ABNT, 2004a).

8 São "quaisquer resíduos que, quando amostrados de uma forma representativa, segundo a ABNT NBR 10007, e submetidos a um contato dinâmico e estático com água destilada ou desionizada, à temperatura ambiente, conforme ABNT NBR 10006, não tiverem nenhum de seus constituintes solubilizados a concentrações superiores aos padrões de potabilidade de água, excetuando-se aspecto, cor, turbidez, dureza e sabor" (ABNT, 2004a). 
orgânico e outros - tecido, vidro, material eletrônico, madeira, etc.. A massa de cada grupo caracterizado (porcentagem individual) será determinado pela Equação (1).

$$
M=(P r / P a) \times 100
$$

Para isso tem-se:

$M=$ Material (\%);

$\operatorname{Pr}=$ Peso da fração do material $(\mathrm{Kg})$;

$P a=$ Peso total da amostra $(\mathrm{Kg})$.

Para tanto, será necessário estabelecer um plano de amostragem, através do qual serão definidos os principais tipos de resíduos. A elaboração deste plano reduz as possibilidades de ocorrência de erros no processo de coleta de dados, garantindo que a caracterização dos resíduos sólidos seja executada de maneira eficiente (GOMES, 2012). Consta na NBR 10007:2004.

plano de amostragem deve ser estabelecido antes de se coletar qualquer amostra, [...] e deve incluir: avaliação do local, forma de armazenamento, pontos de amostragem, tipos de amostradores, número de amostras a serem coletadas, seus volumes, seus tipos (simples ou compostos), número e tipo dos frascos de coleta, métodos de preservação e tempo de armazenagem, assim como os tipos de equipamentos de proteção a serem utilizados durante a coleta. (ABNT, 2004b).

A amostra será definida por meio de quarteamento, processo pelo qual divide-se uma amostra pré- homogeneizada em quatro partes iguais, sendo tomadas duas partes opostas entre si para constituir uma nova amostra e descartadas as partes restantes. As partes não descartadas são misturadas novamente e o processo de quarteamento é repetido até que se obtenha o volume desejado (ABNT, 2004b). 
Os resíduos sólidos caracterizados serão registrados em planilhas juntamente com as fontes geradoras. Este processo visa garantir a correta segregação e destinação dos resíduos, de acordo com sua natureza. Ao fim desta etapa, o pesquisador estará munido com informações referentes à caracterização qualitativa e quantitativa dos resíduos sólidos e das fontes geradoras, o que permitirá seguir com a realização do diagnóstico do manejo de resíduos sólidos no campus.

Além da composição física dos resíduos sólidos gerados no Campus Trindade, será realizado também o cálculo da taxa de geração per capita que, por abranger dados referentes aos volumes coletados e população atendida pelos serviços de coleta, "é um dado fundamental para o planejamento do sistema de gestão do lixo, especialmente no dimensionamento de instalações e equipamentos" (GOMES, 2012, p. 83). Este índice será calculado a partir da quantidade média total pesada em um dia dividida pela quantidade de indivíduos componentes da comunidade acadêmica conforme Equação (2) (GOMES, 2012).

$$
P=(M d / C a) \times 100
$$

Para isso tem-se:

$\mathrm{P}=$ Taxa per capita $(\mathrm{Kg} / \mathrm{pessoa} / \mathrm{dia})$

$M d=$ Massa média diária de resíduos $(\mathrm{Kg}) ;$

$\mathrm{C} a=$ Comunidade Acadêmica (Pessoas).

Para esse fim será considerada comunidade acadêmica todos aqueles que estão de alguma forma vinculados às atividades rotineiras do Campus Trindade, tais como: discentes, docentes, técnicos administrativos e terceirizados responsáveis por serviços de limpeza e vigilância. 


\section{APRESENTAÇÃO E DISCUSSÃO DE RESULTADOS}

A apresentação dos resultados e respectivas discussões serão expostas a seguir em quatro etapas. Primeiro será apresentado o diagnóstico da gestão dos resíduos sólidos gerados no IF Goiano - Campus Trindade. Em seguida serão calculados e analisados os índices de consciência ambiental e de consumo consciente da comunidade acadêmica. Na etapa seguinte serão analisados os perfis de servidores e alunos do Campus Trindade, a fim de se conhecer e traçar um perfil do público estudado. Por fim, será apresentado os dados relativos à caracterização dos resíduos sólidos gerados na unidade.

\subsection{Diagnóstico de Gestão dos Resíduos Sólidos Gerados no Campus Trindade}

A pesquisa referente à estrutura de gestão dos resíduos sólidos no Campus Trindade iniciou-se com a aplicação do Questionário 1, apresentado no Capítulo 3, a partir do qual foi possível obter pré-informações a respeito do tema estudado. Este formulário foi aplicado no período de $1^{\circ}$ a 15 de setembro na Reitoria e foi respondido por todos os gestores ao qual foi direcionado, a saber: reitor, pró-reitores de Desenvolvimento Institucional, Administração, Ensino, Pesquisa, Pós-Graduação e Inovação, e Extensão. Inicialmente o questionário seria aplicado via plataforma on line, mas por sugestão dos gestores, os formulários foram impressos e respondidos na presença da pesquisadora.

No mesmo período em que se iniciou a aplicação do questionário na Reitoria, aplicouse também o mesmo Questionário 1 para servidores docentes, técnico-administrativos e terceirizados do Campus Trindade. O mesmo formulário foi aplicado tanto para os gestores do IF Goiano, quanto para o público do Campus Trindade, com o objetivo de se conhecer, de maneira geral, o conhecimento dos respondentes a cerca da temática tratada. Assim, foi 
possível pontuar os principais pontos relevantes e, também, deficitários em relação ao conhecimento do público sobre o gerenciamento de resíduos sólidos na Instituição.

Para o público do Campus Trindade foi dado também o Questionário 2, para se identificar os níveis de consciência ambiental e consumo consciente da unidade e critérios de compras de seus consumidores, e por isso o prazo de resposta se estendeu até 20 de outubro. Por sugestão dos próprios servidores, os questionários no Campus Trindade também foram aplicados de maneira impressa, pois o funcionamento da internet na unidade não é regular, o que poderia acarretar em dificuldades e até desistências na hora de responder o formulário.

Concomitante à aplicação dos questionários, foram realizadas, visitas locais com o objetivo de se obervar a rotina de funcionamento das atividades do Campus Trindade. Inicialmente foi realizado o mapeamento dos locais onde estão instalados os cestos de lixo na unidade, conforme é apresentado na Figura 3. 
Figura 3 - Plantas por blocos do Campus Trindade

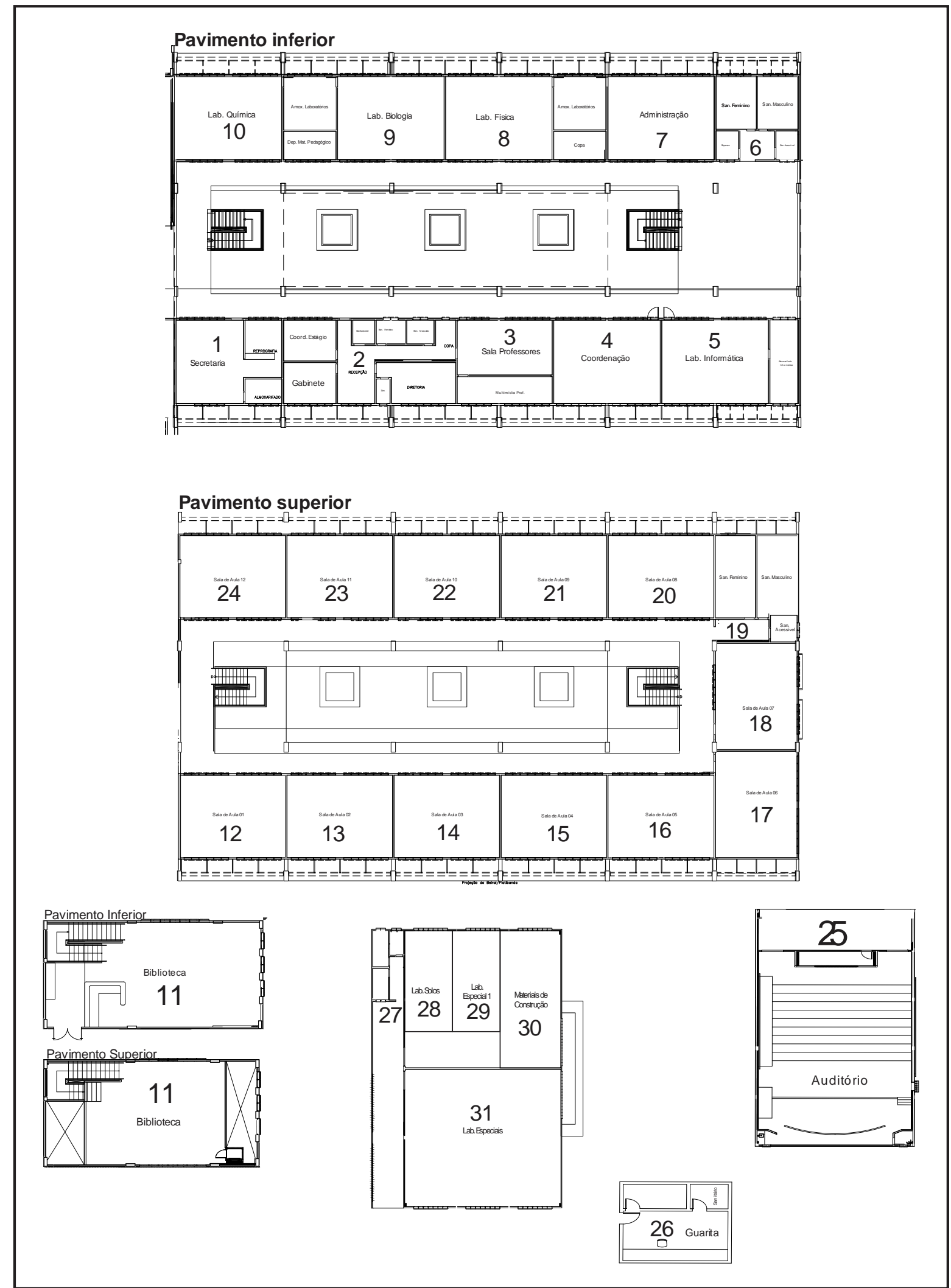

Fonte: Núcleo de Elaboração e Gerenciamento de Projetos de Engenharia e Arquitetura do IF Goiano (figuras sem escala). 
A partir deste mapeamento foi possível identificar os setores, suas atividades, além de possibilitar dimensionar os potenciais geradores de lixo. Cada setor identificado no mapa foi tabelado e especificado de acordo com a sua atividade e número de coletores de lixo presentes no local. Foi observado também se havia separação de resíduos. Os dados foram tabulados conforme mostrado na Tabela 1.

Tabela 1 - Mapeamento dos coletores e identificação se há separação ou não de resíduos recicláveis

\begin{tabular}{|c|c|c|c|c|c|}
\hline \multirow[b]{2}{*}{$\begin{array}{c}\mathbf{n}^{\mathbf{0}} \\
\text { mapa }\end{array}$} & \multirow[b]{2}{*}{ Local } & \multirow[b]{2}{*}{ Quantidade de coletores } & \multicolumn{3}{|c|}{ Há separação? } \\
\hline & & & Sim & Não & $\begin{array}{l}\text { Se sim, quais } \\
\text { materiais? }\end{array}$ \\
\hline & Secretaria & -3 coletores & $\mathrm{X}$ & & - Papel e \\
\hline 01 & & $\begin{array}{l}\text { - } 1 \text { caixa para separação de } \\
\text { recicláveis }\end{array}$ & & & plástico \\
\hline & Coordenação de Estágio & -1 coletor & - & $X$ & - \\
\hline & Gabinete & $\begin{array}{l}-1 \text { coletor } \\
-1 \text { processador de papel }\end{array}$ & - & $\mathrm{X}$ & - \\
\hline & Recepção & -1 coletor & - & $\mathrm{X}$ & - \\
\hline ר) & Diretoria & -1 coletor & - & $\mathrm{X}$ & - \\
\hline 02 & Diretoria - Sanitário & -1 coletor & - & $X$ & - \\
\hline & Sanitário Feminino & -3 coletores & - & $X$ & - \\
\hline & Sanitário Masculino & -2 coletores & - & $\mathrm{X}$ & - \\
\hline & Sanitário Acessível & Inativo & - & $X$ & - \\
\hline & Copa & -1 coletor & - & $\mathrm{X}$ & - \\
\hline 03 & Sala dos Professores & -1 coletor & - & $\mathrm{X}$ & - \\
\hline 04 & Coordenação Pedagógica & - 3 coletores & - & $\mathrm{X}$ & - \\
\hline 05 & $\begin{array}{l}\text { Laboratório de } \\
\text { Informática }\end{array}$ & - 1 coletor & - & $\mathrm{X}$ & - \\
\hline & Sanitário Feminino & -3 coletores & - & $X$ & - \\
\hline 06 & Sanitário Masculino & -2 coletores & - & $\mathrm{X}$ & - \\
\hline & Sanitário Acessível & -1 coletor & - & $\mathrm{X}$ & - \\
\hline 07 & Administração & $\begin{array}{l}\text { - } 3 \text { coletores } \\
\text { - } 1 \text { caixa para separação de } \\
\text { recicláveis }\end{array}$ & $\mathrm{X}$ & & - \\
\hline 08 & Laboratório de Física & Inativo & - & $\mathrm{X}$ & - \\
\hline 09 & Laboratório de Biologia & -2 coletores & - & $X$ & - \\
\hline 10 & Laboratório de Química & Inativo & - & $\mathrm{X}$ & - \\
\hline 11 & Biblioteca & - 3 coletores & - & $X$ & - \\
\hline 12 & Sala 1 & -1 coletor & - & $X$ & - \\
\hline 13 & Sala 2 & - 1 coletor & - & $\mathrm{X}$ & - \\
\hline 14 & Sala 3 & -1 coletor & - & $\mathrm{X}$ & - \\
\hline 15 & Sala 4 & -1 coletor & - & $\mathrm{X}$ & - \\
\hline 16 & Sala 5 & -1 coletor & - & $\mathrm{X}$ & - \\
\hline 17 & Sala 6 & -1 coletor & - & $\mathrm{X}$ & - \\
\hline
\end{tabular}


(Continuação Tabela 1 - Mapeamento dos coletores e identificação se há separação ou não de resíduos

\begin{tabular}{|c|c|c|c|c|c|c|}
\hline \multirow[b]{2}{*}{$\begin{array}{c}\mathbf{n}^{\mathbf{0}} \\
\text { mapa }\end{array}$} & \multirow{2}{*}{\multicolumn{2}{|c|}{ Local }} & \multirow[b]{2}{*}{ Quantidade de coletores } & \multicolumn{3}{|c|}{ Há separação? } \\
\hline & & & & Sim & Não & $\begin{array}{c}\text { Se sim, quais } \\
\text { materiais? }\end{array}$ \\
\hline \multirow{4}{*}{18} & \multicolumn{2}{|c|}{ Coordenação de curso 1} & -1 coletor & - & $\mathrm{X}$ & - \\
\hline & \multicolumn{2}{|c|}{ Coordenação de curso 2} & -1 coletor & - & $X$ & - \\
\hline & \multicolumn{2}{|c|}{ Coordenação de curso 3} & -1 coletor & - & $\mathrm{X}$ & - \\
\hline & \multicolumn{2}{|c|}{ Sanitário Feminino } & Inativo & - & - & - \\
\hline \multirow[t]{2}{*}{19} & \multicolumn{2}{|c|}{ Sanitário Masculino } & Inativo & - & - & - \\
\hline & \multicolumn{2}{|c|}{ Sanitário Acessível } & Inativo & - & - & - \\
\hline 20 & \multicolumn{2}{|l|}{ Sala 8} & -1 coletor & - & $X$ & - \\
\hline 21 & \multicolumn{2}{|l|}{ Sala 9} & -1 coletor & - & $X$ & - \\
\hline 22 & \multicolumn{2}{|l|}{ Sala 10} & -1 coletor & - & $X$ & - \\
\hline 23 & \multicolumn{2}{|l|}{ Sala 11} & -1 coletor & - & $X$ & - \\
\hline \multirow[t]{2}{*}{24} & \multicolumn{2}{|l|}{ Sala 12} & -1 coletor & - & $\mathrm{X}$ & - \\
\hline & & San. Fem. & - & - & $\mathrm{X}$ & - \\
\hline \multirow[t]{2}{*}{25} & \multirow[t]{2}{*}{ Auditório } & San. Mas. & -2 coletores & - & $\mathrm{X}$ & - \\
\hline & & San. Aces. & -1 coletor & - & $\mathrm{X}$ & - \\
\hline \multirow[t]{2}{*}{26} & \multirow{2}{*}{\multicolumn{2}{|c|}{$\begin{array}{l}\text { Guarita - San. } \\
\text { Sanitário Feminino }\end{array}$}} & -1 coletor & - & $\mathrm{X}$ & - \\
\hline & & & -3 coletores & - & $\mathrm{X}$ & - \\
\hline \multirow[t]{2}{*}{27} & \multicolumn{2}{|c|}{ Sanitário Masculino } & -2 coletores & - & $\mathrm{X}$ & - \\
\hline & \multicolumn{2}{|c|}{ Sanitário Acessível } & -1 coletor & - & $\mathrm{X}$ & - \\
\hline 28 & \multicolumn{2}{|c|}{ Laboratório de Solos } & - & - & - & - \\
\hline 29 & \multicolumn{2}{|c|}{ Laboratório Especial 1} & - & - & - & - \\
\hline 30 & \multicolumn{2}{|c|}{ Materiais de Construcão } & - & - & - & - \\
\hline \multirow[t]{3}{*}{31} & \multicolumn{2}{|c|}{ Laboratório Especial } & - & - & - & - \\
\hline & \multirow{2}{*}{\multicolumn{2}{|c|}{ Pátio }} & - 5 Coletores & $\mathrm{X}$ & & $\begin{array}{l}\text { Alguns } \\
\text { coletores } \\
\text { separam } \\
\text { resíduos } \\
\text { recicláveis de } \\
\text { não } \\
\text { recicláveis }\end{array}$ \\
\hline & & & - 2 Baldes (improvisados) & & $X$ & \\
\hline
\end{tabular}

Fonte: autora.

Por orientação do diretor-geral da unidade, neste momento inicial também foi realizado também contato com a servidora responsável pelo Núcleo de Registro Escolar, que é orientadora de um projeto de iniciação científica voltado para a quantificação de resíduos sólidos do Campus Trindade. O trabalho, que visa quantificar os resíduos gerados na unidade por meio de pesagem, é coordenado por uma docente e tem como bolsista uma aluna do curso técnico em Informática Integrado ao Ensino Médio. 
Cruzar as informações conseguidas por meio do questionário, com as observadas no local estudado e obtidas por meio de conversas informais com a servidora responsável pelo projeto de quantificação de resíduos sólidos do Campus Trindade foram determinantes para o diagnóstico da estrutura existente na Instituição. Sobre a existência de ações de sensibilização ambiental, descobriu-se que a unidade promove ações com vistas à sustentabilidade, isso porque a maior parte dos respondentes $(66,7 \%)$ afirmaram existir atividades nesse sentido, enquanto $27,8 \%$ desconhecem tal fato e 5,6\% disseram não existir ações com este fim.

De acordo com os respondentes, a sensibilização ambiental no Campus Trindade é promovida por meio da campanha "Campus Trindade eu amo, eu cuido", que é realizada com o objetivo de conscientizar alunos e servidores para o cuidado com a Instituição. Elaborada no início do funcionamento da unidade, a campanha aborda a conscientização sobre os mais variados aspectos, indo desde o cuidado com o patrimônio até o tratamento interpessoal no bom relacionamento com o próximo. Em vários locais e setores da unidade pode-se encontrar folders e banners sobre os temas abordados (Figura 4), além de servidores usando camisetas com o slogan da campanha. Apesar de tratar do lixo, ao prezar pela limpeza da unidade, a campanha não se refere diretamente à coleta seletiva e tão menos ao gerenciamento de resíduos sólidos. Porém, pode contribuir como instrumento de conscientização, ao preparar servidores e alunos para questões relativas ao cuidado com seu ambiente de trabalho/estudo. 
Figura 4 - Banners no pátio central do Campus Trindade

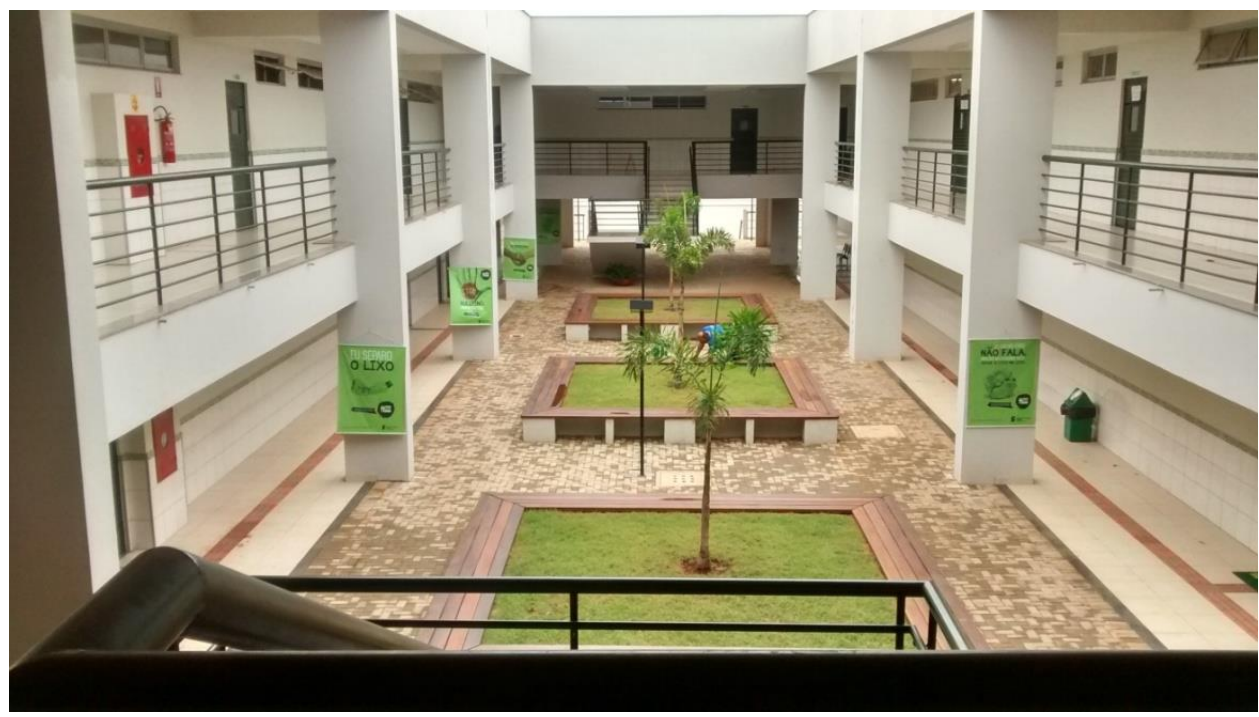

Fonte: Registro da autora.

Sobre a presença de grupo gestor responsável pelo gerenciamento de resíduos sólidos no Instituto Federal Goiano, 80,5\% dos pesquisados mostraram desconhecer a existência desta prática em nível institucional. Porém, no IF Goiano, o gerenciamento de RS é responsabilidade da Agenda Ambiental na Administração Pública (A3P) da Instituição. A A3P funciona por meio de comissão, sendo que cada campus e a reitoria atuam por meio de comissões locais e com representantes em uma comissão central. Atualmente, segundo informações da pró-reitoria de Desenvolvimento Institucional (Prodi), a comissão central está sendo reformulada, para inclusão de novos membros e também elaboração de regimento interno da A3P.

Já no Campus Trindade, o projeto de quantificação dos resíduos sólidos gerados na unidade foi apontado como a atividade responsável pelo gerenciamento de RS na unidade. Até então foram quantificados os resíduos sólidos recicláveis coletados de maio a outubro de 2015. A se deu apenas nas dependências administrativas, o que inclui as salas dos professores, secretaria, gabinete, administração, coordenação e biblioteca. Os dados referentes à pesagem dos resíduos recicláveis coletados foram solicitados à orientadora do projeto, porém não foram disponibilizados para esta pesquisa. 
Em outubro, foi proposta uma ação para separação do lixo incluindo também os coletores localizados no pátio. Nesta ocasião, parte dos cestos de lixo foi identificada para receber resíduos sólidos recicláveis. No dia anterior à distinção dos coletores, alunos e servidores foram avisados pela servidora orientadora do projeto de iniciação científica e pela bolsista, que na época era uma aluna do curso técnico em Edificações Integrado ao Ensino Médio, de que a partir do dia seguinte o lixo deveria ser separado. Foram distribuídos também panfletos para conscientização, conforme modelo apresentado na Figura 5. Essa atividade fez parte da Semana de Ciências e Tecnologia do campus. Porém, durante o processo de caracterização realizado semanas depois se observou que não houve a separação adequada dos resíduos.

Figura 5 - Panfleto de conscientização para separação do lixo distribuído para comunidade acadêmica da unidade

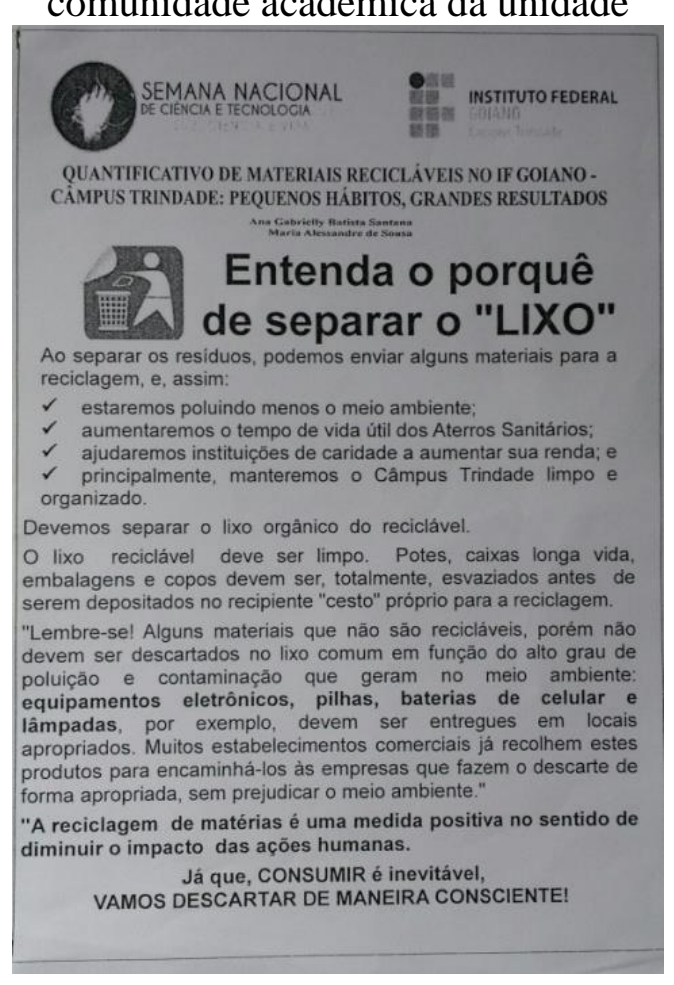

Fonte: Registro da autora.

Por meio do Questionário 1 foi possível verificar que tanto o IF Goiano, em nível institucional, quanto o Campus Trindade, em nível de unidade, não destinam recursos 
específicos para o gerenciamento de resíduos sólidos, além de não possuir também índices de geração de resíduo per capita da Instituição.

Dentre as ações geradoras, os resíduos sólidos do Campus Trindade são provenientes basicamente das atividades rotineiras do trabalho administrativo dos servidores e alunos, tanto em sala de aula, quanto fora dela. Em funcionamento desde o primeiro semestre de 2015, a unidade ainda não possui laboratórios equipados, por isso, ainda não há geração de resíduos laboratoriais específicos. Não há também cantina, refeitório ou lanchonete, porém há muito descarte de restos de alimentos, uma vez que os alunos têm aulas nos dois turnos, matutino e vespertino, e acabam almoçando na Instituição, seja com refeição de casa, ou vendida na porta do Campus. Vale explicar que a unidade fica localizada em região periférica, distante do centro da cidade, e não há restaurantes ou lanchonetes vizinhos. Por isso, vendedores autônomos vendem refeições prontas na entrada da unidade, em embalagens de isopor, fazendo com que os alunos nem precisem sair da Instituição para almoçar.

Durante as visitas foi observada também a rotina dos servidores terceirizados responsáveis pela limpeza da unidade. Ao todo são cinco funcionários, sendo um homem e quatro mulheres, que trabalham de acordo com turnos e escalas. As funcionárias são responsáveis pela limpeza das salas, corredores, banheiros e pátio central. Já ao funcionário cabe a limpeza das áreas externas, que inclui serviços de varrição e capina, quando necessário. Também é ele o responsável pelo transporte do lixo recolhido pelas funcionárias para o container de armazenamento externo, com capacidade de 1.000 litros, e deste para a caçamba externa à Instituição.

No que diz respeito à rotina de manejo dos resíduos sólidos, o lixo é recolhido duas vezes ao dia, uma no período matutino, por volta das $12 \mathrm{~h}$, e outra no vespertino, às $16 \mathrm{~h}$. O material recolhido pelas funcionárias é deixado em local aberto, debaixo da rampa de acesso ao pavimento superior, para que um funcionário responsável possa levá-lo para o container. 
Não existe local adequado para armazenamento temporário do lixo recolhido pelas servidoras terceirizadas. O transporte interno até o container é realizado de maneira manual ou com auxílio de carrinho, dependendo da quantidade e peso do material recolhido. Não é feito controle da quantidade de lixo a ser destinado, nem o peso específico dos resíduos, processo este importante para o dimensionamento dos contêineres e caçambas estacionárias. Também não há a compressibilidade dos resíduos, importante para dimensão dos veículos coletores, estações de transferência com compactação e caçambas compactadoras estacionárias. Além de não haver separação dos resíduos em recicláveis e não recicláveis, também não há tratamento dos mesmos.

A coleta comum do lixo e o recolhimento de caçamba com outros tipos de resíduos, bem como a destinação final é realizada pela prefeitura de Trindade, que não dispõe do serviço de coleta seletiva. Por meio de contato com a Prefeitura, a Secretaria de Meio Ambiente da cidade (Semma), que se colocou à disposição para atuar em parceria com a Instituição no que diz respeito à conscientização de alunos e servidores, oferecendo suporte para realização de palestras e outras ações. A Semma informou ainda que na cidade existe apenas uma cooperativa de catadores de materiais recicláveis, a Cooperativa de Trabalho Dos Catadores de Material Reciclavel de Trindade (Coopertrin). Outro ponto observado refere-se ao descarte de materiais que exige logística reversa. Na unidade não há nenhuma regulamentação para a disposição final de pilhas, lâmpadas, baterias e eletrônicos. Apenas os pneus são deixados nas oficinas quando trocados, ficando por conta do estabelecimento sua destinação final. 


\subsection{Grau de Consciência Ambiental e Consumo Consciente}

Durante a pesquisa, buscou-se identificar também o grau de consciência ambiental e consumo ecologicamente correto e critérios de compra dos consumidores do Campus Trindade por meio da utilização do questionário desenvolvido por Bertolini e Possamai (2005). De uma população de 352 pessoas, composta por servidores e alunos, conseguiu-se uma amostra de 170 questionários respondidos, o que representa $48 \%$ do universo total de pesquisados.

No que se refere ao cálculo do grau de consciência ambiental (Tabelas 2, 3 e 4), foi encontrado o índice de 3,4 para servidores e 3,1 para alunos, o que indica que ambos os grupos possuem "potenciais traços de consciência ambiental", segundo Bertolini e Possamai (2005). Esta característica também se mantém quando o cálculo é realizado de maneira geral, unindo os dois grupos. Nesta situação tem-se um índice de 3,2.

Tabela 2 - Cálculo do grau de consciência ambiental dos servidores do Campus Trindade

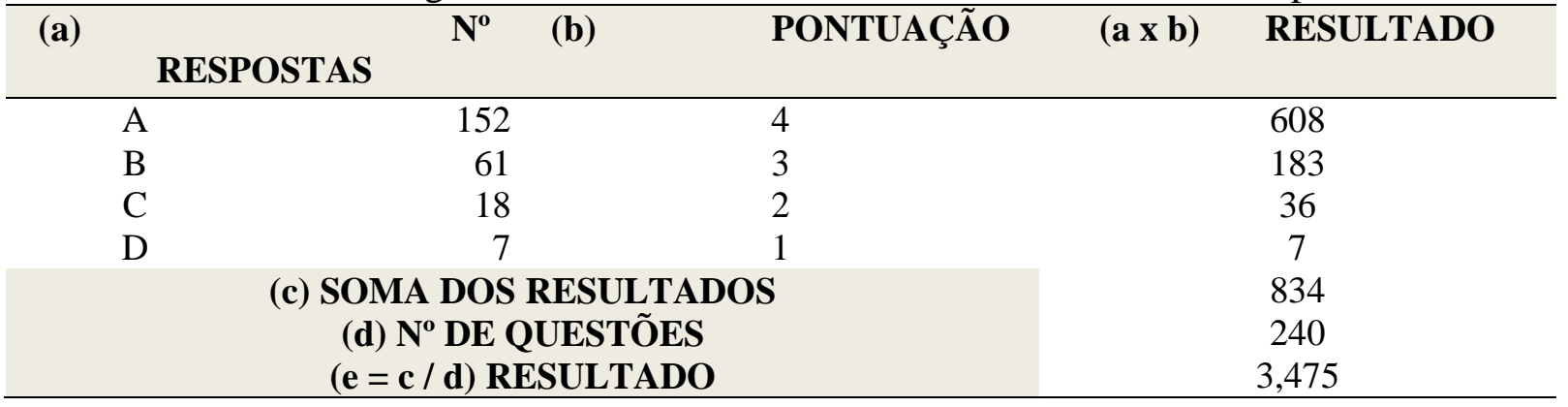

Tabela 3 - Cálculo do grau de consciência ambiental dos alunos do Campus Trindade

\begin{tabular}{|c|c|c|c|c|}
\hline \multicolumn{4}{|c|}{ RESPOSTAS } & RESULTADO \\
\hline $\mathrm{A}$ & 486 & 4 & & 1944 \\
\hline B & 370 & 3 & & 1110 \\
\hline $\mathrm{C}$ & 179 & 2 & & 358 \\
\hline D & 79 & 1 & & 79 \\
\hline \multicolumn{3}{|c|}{$\begin{array}{l}\text { (c) SOMA DOS RESULTADOS } \\
\text { (d) } \mathbf{N}^{\circ} \text { DE QUESTÕES } \\
(\mathbf{e}=\mathbf{c} / \mathrm{d}) \text { RESULTADO }\end{array}$} & & $\begin{array}{l}3491 \\
1120 \\
3,116\end{array}$ \\
\hline
\end{tabular}


Tabela 4 - Cálculo do grau de consciência ambiental dos servidores e alunos do Campus Trindade

\begin{tabular}{|c|c|c|c|c|}
\hline (a) & $\begin{array}{ll}\mathbf{N}^{\mathbf{0}} & \text { (b) } \\
\end{array}$ & PONTUAÇÃOO & $(\mathbf{a} \times \mathbf{b})$ & RESULTADO \\
\hline $\mathrm{A}$ & 638 & 4 & & 2552 \\
\hline B & 431 & 3 & & 1293 \\
\hline $\mathrm{C}$ & 197 & 2 & & 394 \\
\hline $\mathrm{D}$ & 86 & 1 & & 86 \\
\hline \multicolumn{3}{|c|}{$\begin{array}{l}\text { (c) SOMA DOS RESULTADOS } \\
\text { (d) } \mathbf{N}^{\circ} \text { DE QUESTÕES } \\
(\mathrm{e}=\mathrm{c} / \mathrm{d}) \text { RESULTADO }\end{array}$} & & $\begin{array}{l}4325 \\
1360 \\
3,18\end{array}$ \\
\hline
\end{tabular}

Já o índice referente ao grau de consumo ecologicamente correto (Tabelas 5, 6 e 7) apresentou divergências quando comparado os dois grupos. Enquanto os servidores apresentam "potenciais traços de consumo ecologicamente correto" (2,5), os alunos mostraram "fracos traços de consumo ecologicamente correto" $(2,4)$. No cálculo do índice geral $(2,4)$, a característica demonstrada pelo grupo dos alunos acabou prevalecendo e mostrando que a maioria dos indivíduos possuem "fracos traços de consumo ecologicamente correto".

Tabela 5 - Cálculo do grau de consumo ecologicamente correto dos servidores e alunos do

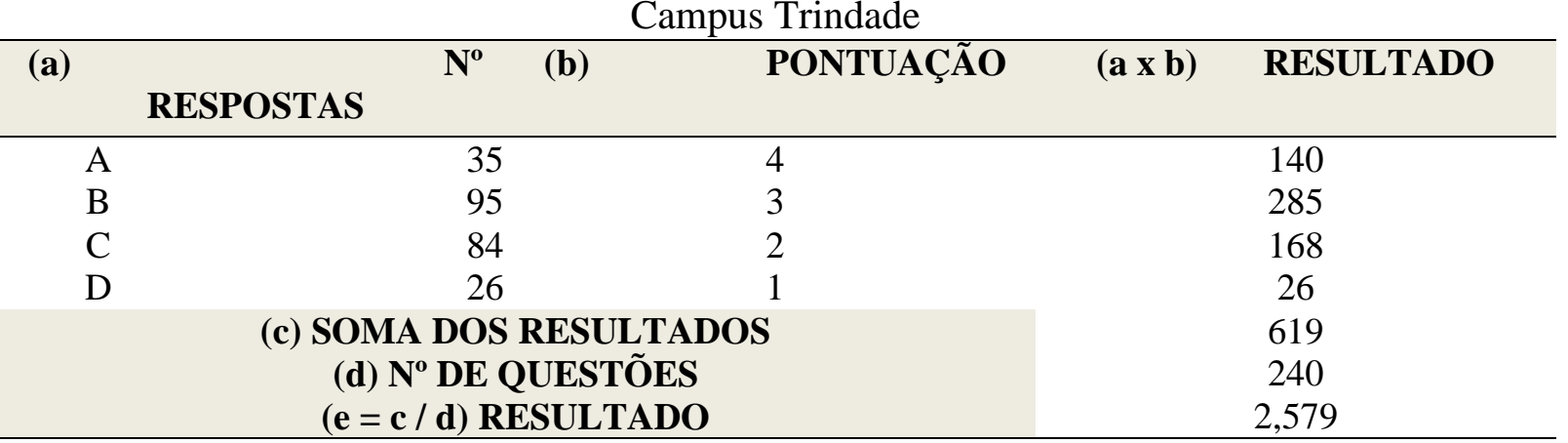

Tabela 6 - Cálculo do grau de consumo ecologicamente correto dos alunos do Campus Trindade

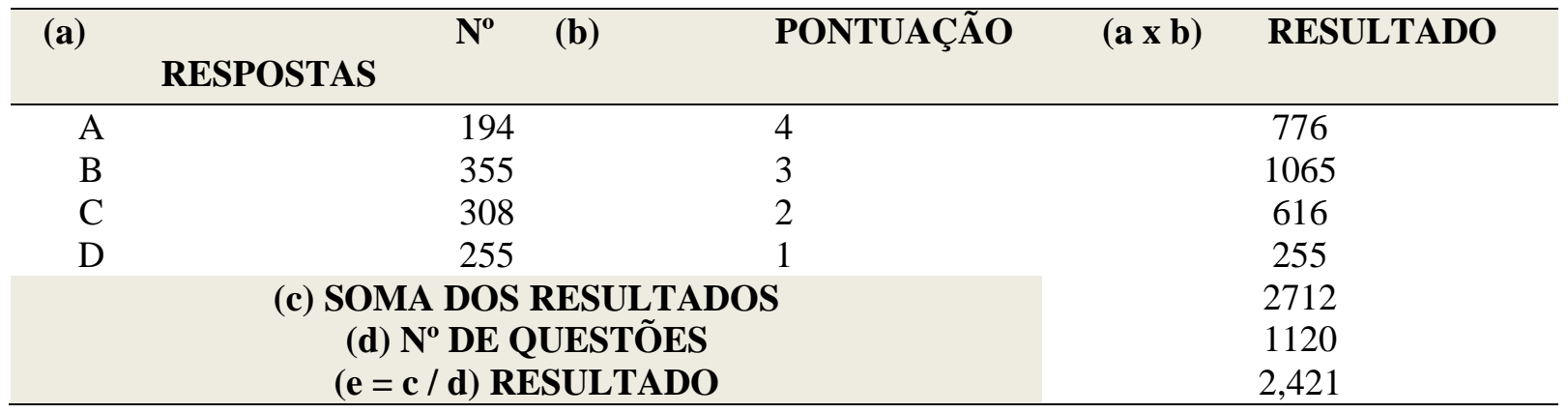


Tabela 7 - Cálculo do grau de consumo ecologicamente correto dos servidores e alunos do

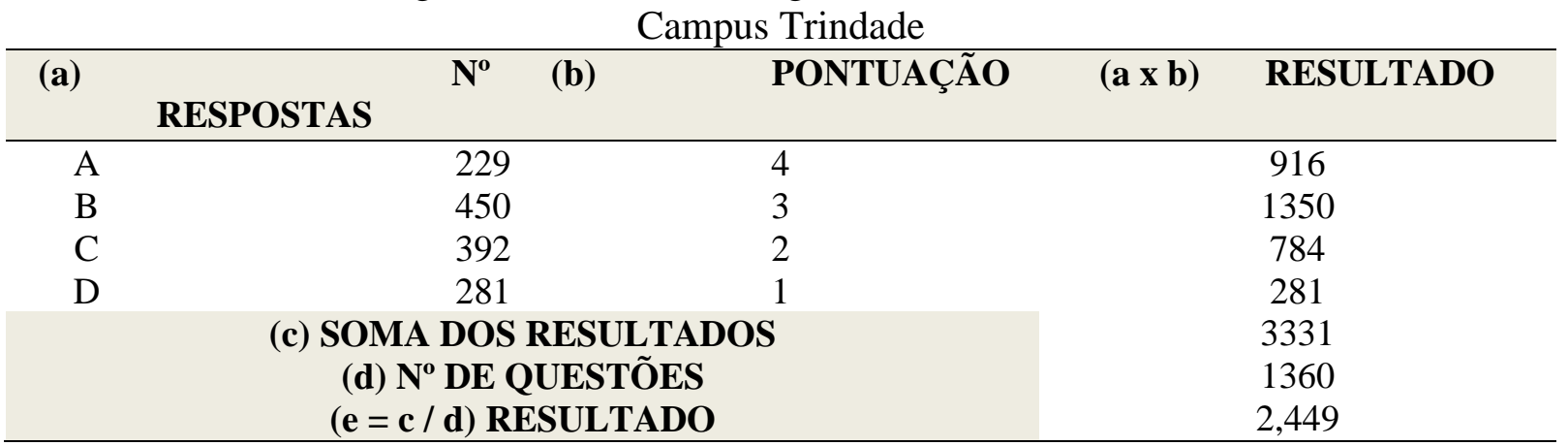

\subsection{Análise do Perfil dos Servidores e Alunos do Campus Trindade}

Paralelamente ao diagnóstico do manejo de resíduos sólidos e identificação do grau de consciência ambiental, consumo ecologicamente correto e critérios de compras dos consumidores do Campus Trindade, foi possível conhecer o perfil de servidores e alunos da unidade por meio das informações obtidas pelos questionários 1 e 2 . Foram analisadas as variáveis idade, gênero e tempo de serviço público, para o grupo composto pelos servidores, e gênero, idade e renda, para o se conhecer o perfil dos alunos.

Da população de 65 funcionários, dentre servidores docentes, técnico-administrativos e terceirizados do Campus Trindade, mais os cinco pró-reitores e reitor da Instituição, obtevese uma amostra de 36 questionários respondidos, que representa 47,4\% do universo total da população estudada. A amostra se apresentou com relativa predominância dos homens, sendo $58 \%$ dos respondentes do sexo masculino, contra $42 \%$ do sexo feminino. Segundo análise processada pelo programa Statistical Package for the Social Sciences (SPSS), a média de idade foi de 38,2 anos, com desvio padrão de \pm 8,82 (Figura 6), sendo a faixa etária de 35 a 49 anos correspondente à 51,4\% do total de pesquisados (Tabela 8). 
Figura 6 - Gráfico da frequência da idade média dos servidores do Campus Trindade

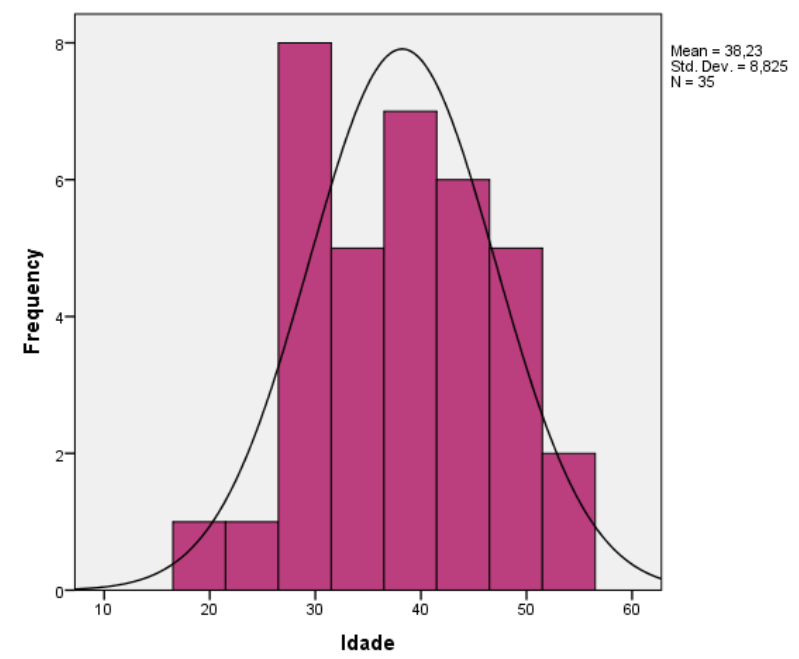

Fonte: Dados da pesquisa.

Tabela 8 - Percentual por faixa etária dos servidores do Campus Trindade

\begin{tabular}{|c|c|c|c|c|c|}
\hline \multicolumn{6}{|c|}{ Faixa etária } \\
\hline & & Frequência & Percentual & $\begin{array}{l}\text { Percentual } \\
\text { válido }\end{array}$ & $\begin{array}{l}\text { Percentual } \\
\text { acumulado }\end{array}$ \\
\hline \multirow{5}{*}{ Valid } & até 20 anos & 1 & 2,8 & 2,9 & 2,9 \\
\hline & de 21 a 34 anos & 12 & 33,3 & 34,3 & 37,1 \\
\hline & de 35 a 49 anos & 18 & 50,0 & 51,4 & 88,6 \\
\hline & 50 anos ou mais & 4 & 11,1 & 11,4 & 100,0 \\
\hline & Total & 35 & 97,2 & 100,0 & \\
\hline Missing & System & 1 & 2,8 & & \\
\hline Total & & 36 & 100,0 & & \\
\hline
\end{tabular}

Fonte: Dados da pesquisa.

Em relação ao tempo médio de serviço público, quase metade da amostra $(47,1 \%)$ possui de 4 a 15 anos, seguidos daqueles que ainda estão em estágio probatório, ou seja, têm até 3 anos de serviço público $(29,4 \%)$. Considerando a possibilidade de aposentadoria tanto por idade, quanto por tempo de serviço público (levando-se em conta apenas o tempo de trabalho declarado na pesquisa), os dados evidenciam uma estrutura funcional composta por um quadro de funcionários jovens, compondo assim, um ambiente favorável para a implementação de uma nova cultura institucional, voltada para as práticas de sustentabilidade. Por fazerem parte do início do funcionamento da unidade, pode-se acreditar que estes servidores se sintam ainda mais responsáveis pelo funcionamento e manutenção eficientes do campus. 
No grupo dos alunos, ainda que a diferença seja mínima, a maior parte dos alunos da amostra são representantes do sexo feminino (51\%), sendo a idade de 15 anos predominante entre os estudantes $(57,1 \%)$. Identificar o perfil de servidores e alunos se fez importante por mostrar as características do público estudado, norteando assim, as ações a serem implementadas de maneira mais específica. Saber o perfil dos servidores e alunos permitirá, por exemplo, direcionar e tornar as ações e estratégias de comunicação para um trabalho de conscientização mais eficiente.

\subsection{Caracterização dos Resíduos Sólidos}

Já a caracterização dos resíduos sólidos consiste em uma ferramenta essencial para compreender o comportamento físico dos elementos que compõem os resíduos sólidos, bem como seus fluxos, desde a coleta até o destino final. Além disso, é importante por viabilizar subsídios para dimensionar a quantidade de lixo produzido em cada área, fornecendo dados mais precisos para a elaboração de um modelo de gestão ambientalmente correto e economicamente viável (GOMES, 2012). As informações obtidas foram registradas em planilhas. Este processo visou garantir a correta segregação e destinação dos resíduos, de acordo com sua natureza.

O projeto inicial previa a realização da caracterização por amostragem, com utilização da técnica de quarteamento, porém diante do baixo quantitativo total de resíduos sólidos gerado pelo Campus Trindade trabalhou-se com a massa total produzida diariamente na unidade. O parâmetro de comparação utilizado baseou-se nos trabalhos de caracterização realizados em Instituições como a USP e a PUC-RIO, cujas metodologias contidas nos planos de gestão de resíduos sólidos contribuíram para elaboração deste PGRS. 
A caracterização foi realizada em uma sala ampla e ventilada, localizada no prédio de laboratórios, situado na parte inferior do campus. Este ambiente garantiu a integridade do material pesquisado em relação a possíveis alterações climáticas como ventos e chuvas. Parte do piso da sala foi coberto por uma lona preta de $16 \mathrm{~m}^{2}$ para que todo resíduo recolhido pudesse ser despejado e separado. Além da pesquisadora, participaram da caracterização dos resíduos sólidos a servidora orientadora do projeto de iniciação científica, a bolsista do projeto e um funcionário da limpeza. Toda equipe foi munida de equipamentos de proteção individual (EPIs).

Durante as duas semanas foi acordado com a equipe de limpeza que o lixo recolhido dos sanitários seriam armazenados em sacos plásticos da cor azul, diferente dos usados nas demais dependências da unidade, que são da cor preta. Compreendem os resíduos gerados no banheiro todos aqueles descartados nesse ambiente, como os resíduos depositados nos coletores individuais das cabines e na lixeira de resíduos para papel de secagem de mãos. Os sacos provenientes dos sanitários foram considerados rejeitos e por isso foram apenas pesados e não abertos. O lixo descartado nos banheiros "é um material contaminado que, apesar da eventual presença de algum outro tipo de resíduo não característico desse ambiente, não é viável a sua segregação manual” (MMA, 2015). Para tanto foi utilizado balança digital com plataforma e coluna em aço carbono (Figura 7). O lixo era recolhido até às $16 \mathrm{~h}$ e pesado por volta das $17 \mathrm{~h}$. Todo o processo de pesagem era realizado em um período médio de três horas. 
Figura 7 - Balança utilizada para pesagem dos resíduos utilizados para caracterização gravimétrica

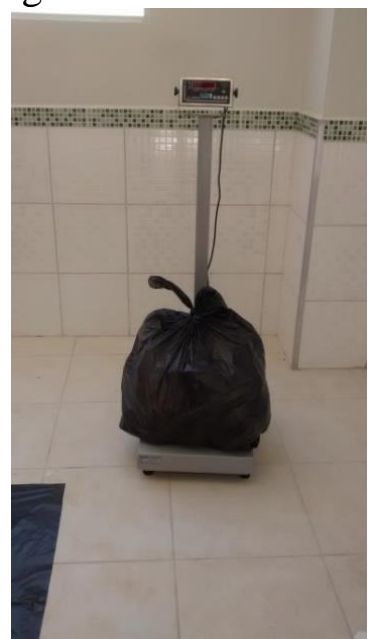

Fonte: Registro feito pela autora.

Inicialmente quantificou-se e pesou-se todos os sacos recolhidos, a fim de se verificar a massa de resíduos total gerada no dia (Tabela 9). Observou-se que os sacos utilizados nos coletores eram de 100 litros, porém, na maioria das vezes eles eram recolhidos antes de atingirem sua capacidade total, ocasionando assim, mau uso/desperdício deste material. Dessa forma o número de sacos quantificados não representa a real necessidade de demanda de uso do produto. Depois os sacos, com exceção daqueles identificados como rejeitos, eram abertos e seus conteúdos eram depositados sobre a lona para serem separados. Tal procedimento pode ser visto nas Figuras 8 e 9. Após a triagem, foi possível caracterizar os materiais separados segundos os seguintes grupos: plástico fino, plástico rígido, papel, embalagem metalizada, isopor, embalagem longa vida, alumínio, matéria orgânica, rejeitos banheiro e outros.

Tabela 9 - Quantidade de sacos plásticos recolhidos por dia no Campus Trindade

\begin{tabular}{|cccccc|}
\hline Semana 1 & $\begin{array}{c}\text { Sacos de lixo } \\
\text { recolhidos } \\
\text { (unid.) }\end{array}$ & $\begin{array}{c}\text { Peso } \\
(\mathbf{K g})\end{array}$ & Semana 2 & $\begin{array}{c}\text { Sacos de lixo } \\
\text { recolhidos } \\
\text { (unid.) }\end{array}$ & $\begin{array}{c}\text { Peso } \\
\text { (Kg) }\end{array}$ \\
\hline $09 / 11 / 15$ & 6 & 4,650 & $16 / 11 / 15$ & 18 & 12,950 \\
\hline $10 / 11 / 15$ & 17 & 24,550 & $17 / 11 / 15$ & 19 & 19,470 \\
\hline $11 / 11 / 15$ & 20 & 17,800 & $18 / 11 / 15$ & 22 & 12,450 \\
\hline $12 / 11 / 15$ & 21 & 27,550 & $19 / 11 / 15$ & 21 & 16,400 \\
\hline $13 / 11 / 15$ & 19 & 16,350 & $20 / 11 / 15$ & 24 & 15,100 \\
\hline TOTAL: & $\mathbf{8 3}$ & $\mathbf{9 0 , 9 0 0}$ & TOTAL: & 104 & $\mathbf{7 6 , 3 7 0}$ \\
\hline
\end{tabular}

Fonte: Dados da pesquisa. 
Figura 8 - Abertura dos sacos de lixo para posterior processo de triagem

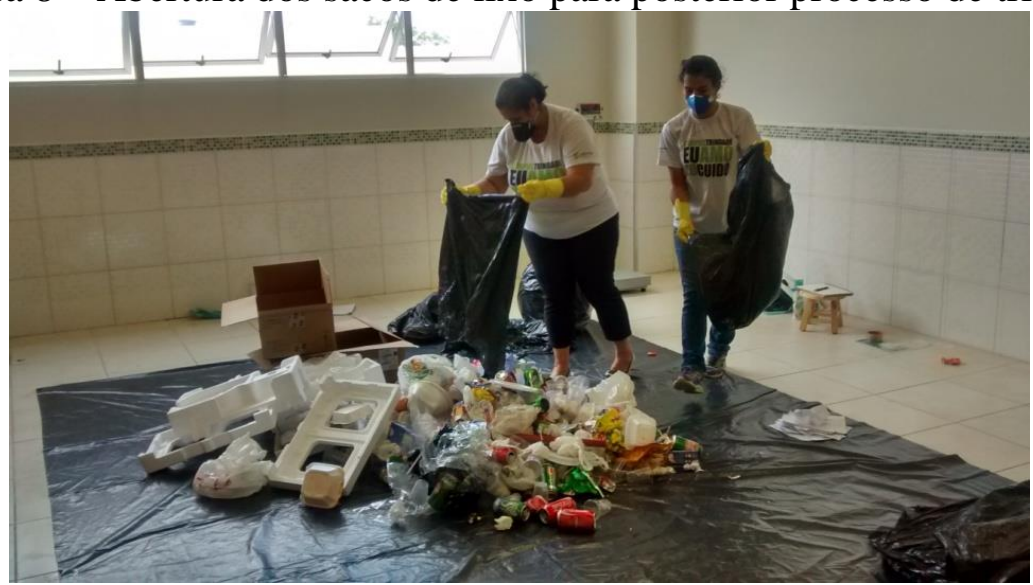

Fonte: Registro feito pela autora.

Figura 9 - Triagem dos resíduos e separação em categorias

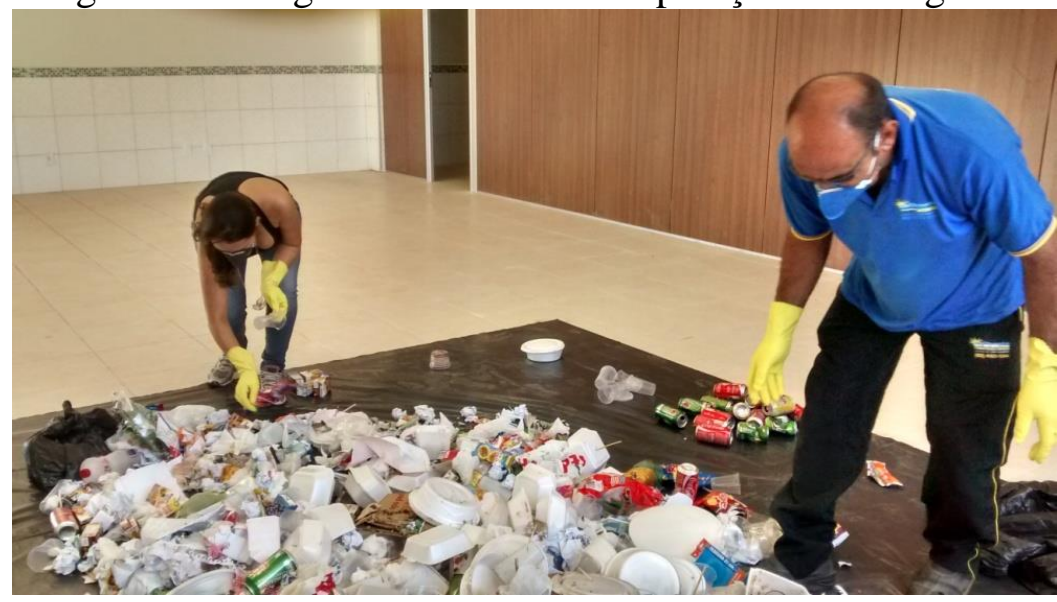

Fonte: Registro feito pela autora.

A média semanal de lixo gerada no Campus Trindade foi de $83,6 \mathrm{~kg}$, sendo que na primeira semana foi pesada a quantidade de $90,9 \mathrm{~kg}$, enquanto na segunda esse número foi de $76,3 \mathrm{~kg}$. Do total da massa de resíduos pesadas em duas semanas na unidade, a quantidade de rejeitos corresponde à cerca de $7 \%$, enquanto $93 \%$ é composto pelos demais resíduos. Vale ressaltar que, por não existir ações de coleta seletiva e/ou segregação do lixo, houve a presença de rejeitos dentre o material caracterizado. As informações referentes à caracterização gravimétrica são apresentadas abaixo na Tabela 10. 
Tabela 10 - Caracterização gravimétrica dos resíduos gerados no Campus Trindade

\begin{tabular}{|c|c|c|c|c|c|c|c|c|c|c|c|c|c|c|}
\hline & \multirow{2}{*}{$\begin{array}{l}\text { Rejeitos } \\
\text { Banheiro }\end{array}$} & \multirow{2}{*}{\begin{tabular}{|l} 
Demais \\
Residuos
\end{tabular}} & \multirow{2}{*}{$\begin{array}{c}\text { Total } \\
\text { Residuos }\end{array}$} & \multirow{2}{*}{$\begin{array}{l}\text { Plástico } \\
\text { fino }\end{array}$} & \multicolumn{2}{|c|}{ Plástico Rígido } & \multirow{2}{*}{ Papel } & \multirow{2}{*}{\begin{tabular}{|c|} 
Embalagem \\
metalizada
\end{tabular}} & \multirow{2}{*}{ Isopor } & \multirow{2}{*}{$\begin{array}{l}\text { Embalagem } \\
\text { longa vida }\end{array}$} & \multirow{2}{*}{ Alumínio } & \multirow{2}{*}{$\begin{array}{l}\text { Matéria } \\
\text { Orgânica }\end{array}$} & \multirow{2}{*}{ Outros } & \multirow{2}{*}{$\begin{array}{c}\text { Soma } \\
\text { Caracterização }\end{array}$} \\
\hline & & & & & $\begin{array}{c}\text { Copo } \\
\text { plástico }\end{array}$ & Outros & & & & & & & & \\
\hline $09 /$ nov & 2,100 & 2,550 & 4,650 & 0,300 & 0,100 & 0,200 & 0,350 & 0,050 & 0,100 & 0,050 & 0,100 & 1,300 & 0,000 & 2,550 \\
\hline $10 /$ nov & 1,200 & 23,350 & 24,550 & 0,250 & 0,850 & 0,950 & 1,050 & 0,100 & 0,950 & 1,050 & 0,850 & 17,300 & 0,000 & 23,3 \\
\hline $11 /$ nov & 1,250 & 16,550 & 17,800 & 0,400 & 0,600 & 0,800 & 1,430 & 0,150 & 0,700 & 0,800 & 0,900 & 10,770 & 0,000 & 16,55 \\
\hline $12 /$ nov & 1,400 & 26,150 & 27,550 & 0,500 & 0,950 & 1,400 & 0,600 & 0,150 & 0,850 & 0,850 & 1,000 & 19,850 & 0,000 & $26,15 \mathrm{C}$ \\
\hline $13 /$ nov & 0,950 & 15,400 & 16,350 & 0,350 & 0,550 & 0,750 & 1,300 & 0,100 & 0,600 & 0,700 & 0,800 & 10,250 & 0,000 & 15,400 \\
\hline $16 /$ nov & 0,750 & 12,200 & 12,950 & 0,200 & 0,350 & 0,550 & 0,350 & 0,050 & 0,450 & 0,450 & 0,450 & 8,950 & 0,400 & 12,200 \\
\hline $17 /$ nov & 0,850 & 18,620 & 19,470 & 0,700 & 0,500 & 0,900 & 2,850 & 0,150 & 0,750 & 1,200 & 0,750 & 10,820 & 0,000 & 18,620 \\
\hline $18 /$ nov & 1,000 & 11,450 & 12,450 & 0,250 & 0,450 & 0,450 & 1,200 & 0,100 & 0,800 & 0,650 & 0,750 & 6,800 & 0,000 & $11,45 \mathrm{C}$ \\
\hline $19 /$ nov & 0,800 & 15,600 & 16,400 & 0,250 & 0,550 & 0,650 & 0,650 & 0,100 & 0,600 & 0,750 & 0,900 & 11,150 & 0,000 & 15,600 \\
\hline $20 /$ nov & 1,250 & 13,850 & 15,100 & $1,000^{\circ 0}$ & 0,450 & 0,700 & 2,050 & 0,100 & 0,750 & 0,650 & 0,450 & 8,700 & 0,000 & 13,850 \\
\hline TOTAL: & 11,550 & 155,720 & 167,270 & 3,200 & 5,350 & 7,350 & 11,830 & 1,050 & 6,550 & 7,150 & 6,950 & 105,890 & 0,400 & 155,7 \\
\hline
\end{tabular}

Fonte: Dados da pesquisa.

Os dados relativos às porcentagens individuais do resíduo amostrado foram obtidos por meio da Equação (1) apresentada no Capítulo 3 - Metodologia. Na Tabela 11 é apresentado o desenvolvimento da Equação (1) para cada classe de material triado.

Tabela 11 - Determinação percentual da composição do lixo do Campus Trindade em 2015

\begin{tabular}{|l|c|c|c|}
\hline \multicolumn{4}{|c|}{ Cálculo percentual da composição gravimétrica } \\
\hline Material & Porcentagem (\%) & Material & Porcentagem (\%) \\
\hline Matéria Orgânica & $\mathbf{6 8 , 0 \%}$ & Isopor & $\mathbf{4 , 0 \%}$ \\
\hline Papel & $\mathbf{8 , 0 \%}$ & Alumínio & $\mathbf{4 , 0 \%}$ \\
\hline Plástico Rígido & $\mathbf{8 , 0 \%}$ & Plástico Fino & $\mathbf{2 , 0 \%}$ \\
\hline Embalagem longa vida & $\mathbf{5 , 0 \%}$ & Outros & $\mathbf{1 , 0 \%}$ \\
\hline
\end{tabular}

Fonte: Dados da pesquisa.

Observou-se que os resíduos orgânicos compõem quase $70 \%$ do lixo produzido pela Instituição diariamente. Nesse grupo predominou os restos de comidas provenientes do almoço, principalmente dos alunos, que ficam no Campus nos períodos matutino e vespertino. Estes estudantes não têm como se deslocarem até suas casas para almoçar, nem como ir a um restaurante, pois a Instituição situa-se em uma região mais periférica, distante de restaurantes e outros tipos de comércios. Assim, considerando a relação distância-tempo, torna-se inviável 
a saída destes alunos nesse período entre os turnos, uma vez que a maioria deles não possuem condução própria, nem mesmo idade para dirigir. Então, apesar da Instituição ainda não contar com estruturas de refeitório e lanchonetes, a massa de material orgânico proveniente de restos alimentares já predomina no campus.

Outro ponto a ser destacado em relação aos resíduos orgânicos refere-se ao fato de que, pelo descarte do lixo ser feito sem qualquer trabalho de segregação muitos materiais passíveis de reciclagem acabam se perdendo por se misturar a esse tipo de resíduo, também denominado como lixo úmido. Tal fato foi muito observado no processo de caracterização dos resíduos sólidos da unidade e acabou por gerar perdas durante a triagem, resultando na diminuição do valor percentual real de participação de determinado material na massa total caracterizada para a pesquisa.

Com $8 \%$ de representatividade dentro da quantidade triada, o grupo caracterizado como papel foi um exemplo da situação descrita anteriormente. Composto basicamente por folhas de caderno ou papel sulfite e papelão, grande parte destes materiais não puderam ser separados e pesados por terem sido afetados pelos resíduos orgânicos. Sobre este grupo há de se observar que, por se tratar de um ambiente escolar e também administrativo, onde há relevante uso de papel, o descarte deste material exige uma atenção diferenciada para que se evitem perdas desnecessárias que prejudicam o processo de reciclagem. O reaproveitamento também pode ser bastante explorado nesse caso, principalmente na área administrativa.

Também com $8 \%$, aparece o grupo composto por materiais de plástico rígido, que foi subdividido em duas categorias: copos plásticos (3\%) e outros - garrafas PET, potes plásticos e embalagens de iogurte (5\%). Quando comparada a outras Instituições, a quantidade de copos plásticos gerada pelo Campus Trindade se mostrou relativamente alta. No Campus Gávea da PUC-Rio, por exemplo, cujo plano de gerenciamento de resíduos sólidos foi utilizado como referência para realização desta pesquisa. a média de copos plásticos 
representa cerca de $6 \%$ dos resíduos gerados na instituição, para um público de 20.844 pessoas entre alunos e servidores. Vale destacar, porém, que na universidade já era desenvolvido programa de reciclagem e conscientização ambiental. Para a redução do consumo de copos descartáveis, poderão ser implementadas ações que visem o incentivo ao uso de garrafas de água e copos reutilizáveis.

Pelo fato do plástico ser um material extremamente danoso ao meio ambiente, seu uso deve ser controlado e por isso, na maioria das vezes, a redução e posterior não utilização de copos plásticos são algumas das primeiras ações estratégicas de gerenciamento de resíduos sólidos. Já a utilização de plástico fino, grupo composto por sacos e sacolas ficou mais abaixo, com $2 \%$ de representatividade em relação a massa total de resíduos triada. Porém, apesar de apresentar um percentual pouco expressivo, este material "traz dificuldades em instalações de tratamento, tais como aterros sanitários e em usinas de compostagem (criando nichos, impedindo livre trânsito de líquidos e gases)" (BIDONE, 1999, p. 24). Durante a triagem foi muito comum encontrar sacolas amarradas contendo uma lata de refrigerante e uma marmita de isopor com restos de comida dentro.

As embalagens longa vida, que apareceram na forma de caixas de suco e achocolatados, representaram 5\% dos resíduos caracterizados. Observou-se que muitas vezes elas, assim como as garrafas PET e de iogurte, são descartadas com bebidas dentro, o que acaba por danificar outros materiais que poderiam ser recicláveis, como pode ser observado na Figura 11. A mesma situação foi registrada para as latinhas de alumínio e as embalagens de isopor, ambas representando $4 \%$ cada uma do total de resíduos caracterizados. No caso do isopor, que compõe as embalagens de marmita, o conteúdo são restos alimentares, o que acaba atraindo moscas e formando larvas. Com a implantação do plano de gerenciamento de resíduos sólidos os usuários do Campus Trindade deverão ser orientados a esvaziarem todos os recipientes antes do seu descarte. 
Figura 11 - Garrafa pet descartada com bebida dentro

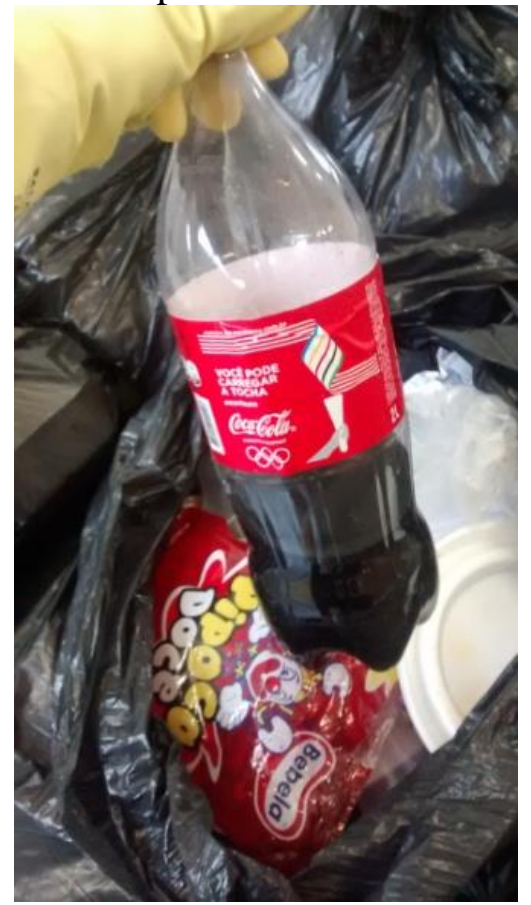

Fonte: Registro da autora.

Por fim, foram caracterizados aqueles materiais que, devido à baixa frequência e também ao descarte errado, foram denominados como outros e representaram $1 \%$ dos resíduos pesquisados. Neste grupo houve predomínio das embalagens metalizadas, representando $(0,7 \%)$ do total pesado. Foi possível perceber também algumas deficiências, como o descarte de disjuntor e até pilhas no lixo comum da Instituição, conforme ilustra Figura 12.

Figura 12 - Disjuntor e pilhas encontradas no lixo comum da

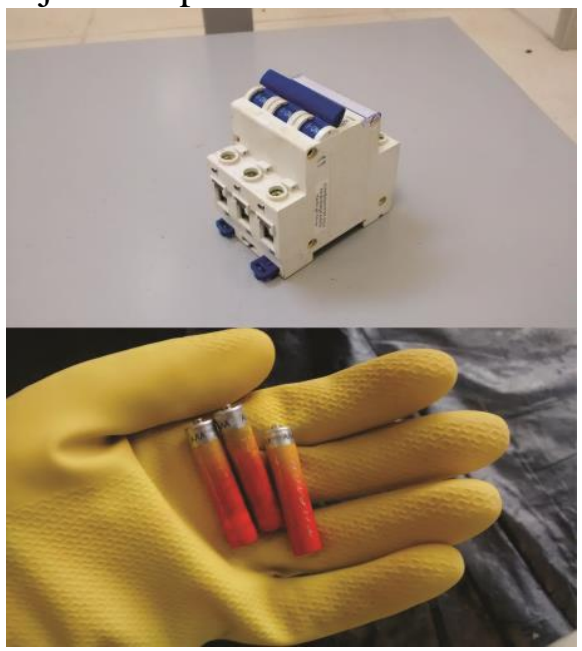

Fonte: Registro da autora. 
Para a estimativa da taxa de geração per capita foi considerado como universo os docentes, técnicos administrativos, discentes e servidores terceirizados, somando um total de 352 pessoas, sendo: 287 alunos, 31 professores, 20 técnicos administrativos e 14 terceirizados. Vale ressaltar que o público denominado como flutuante, ou seja, aqueles que moram ou estudam próximos à Instituição e a utilizam como área de lazer, descanso e rota de passagem, foi desconsiderado por ser praticamente irrelevante e estar presente apenas em eventos pontuais. Assim, a partir do desenvolvimento da equação (2), estima-se que cada indivíduo descarta uma média diária de $0,047 \mathrm{~kg}$ de resíduos sólidos durante sua permanência na Instituição.

Quando comparado à faixa de variação média de geração per capita definida pelo manual desenvolvido pelo Ministério da Ação Social e Secretaria Nacional e Saúde (1991), que define o patamar de 0,5 a $0,8 \mathrm{~kg} / \mathrm{habitante} / \mathrm{dia}, \mathrm{o}$ índice apresentado pelo Campus Trindade pode ser considerado positivo. Também em relação aos estudos realizados em outras universidades, este número se mostra dentro das médias. A Escola Politécnica da Universidade de São Paulo (2013), apresentou uma geração per capita de 0,107 Kgdia/hab, enquanto a Pontifícia Universidade Católica do Rio de Janeiro - Campus Gávea (2010), este índice sobe para 0,120 kg/hab/dia. A diferença do peso de descarte per capita entre o Campus Trindade e as outras duas Instituições citadas pode se justificar em decorrência da vasta gama de oportunidades de consumo existente nas universidades, estruturas estas que ainda não estão disponíveis na primeira.

De posse das informações e análises obtidas a partir da identificação dos graus de consciência ambiental, consumo consciente e critérios de compra dos consumidores, da caracterização quali e quantitativa dos resíduos sólidos descartados pela comunidade acadêmica e da definição do índice de geração per capita do IF Goiano - Campus Trindade, a pesquisa seguirá para a fase de elaboração do PGRS da Instituição. Dessa forma, no 
próximo capítulo serão expostas medidas corretivas, para aquelas ações que já são praticadas, mas fora dos padrões, e inéditas, para situações que ainda não são desenvolvidas na unidade, segundo as dimensões abordadas no diagnóstico (sensibilização, gerenciamento, geração, coleta, acondicionamento, transportes interno e externo, tratamento, armazenamento, coleta, disposição final e monitoramento) e forma a viabilizar a implantação do Plano do Campus Trindade. 


\section{ELABORAÇÃO DO PLANO DE GESTÃO DE RESÍDUOS SÓLIDOS DO IF GOIANO - CAMPUS TRINDADE}

Este capítulo aborda as questões referentes à definição e implementação do Plano de Gerenciamento de Resíduos Sólidos do Campus Trindade e, por isso está dividido em dois tópicos, sendo um para cada tema. Cabe destacar que este PGRS foi elaborado com base no conteúdo mínimo previsto na PNRS (Art. 21) e segundo as diretrizes adotadas pelo Plano desenvolvido pelo Ministério do Meio Ambiente (MMA, 2015), que são:

- Responsabilidade na ação - a administração pública deve liderar a sua atuação pelo exemplo;

- Mudanças necessárias e urgentes - as práticas de sustentabilidade envolvem mudanças nos hábitos e comportamentos pessoais e na cultura institucional. Apesar de difíceis, elas precisam ser enfrentadas e transformadas;

- Contratações Sustentáveis - um bom gerenciamento de resíduos sólidos deve estar aliado ao consumo sustentável dos produtos adquiridos pela administração pública, cuja aquisição deve ser norteada por princípios de responsabilidade socioambiental;

- Educação Ambiental - para que a sustentabilidade seja, de fato, incorporada nas instituições públicas, é fundamental que as iniciativas de educação ambiental junto aos gestores públicos e servidores façam parte do processo de mudança;

- Comunicação e informação - as mudanças necessárias e os resultados obtidos com a implementação do plano devem fazer parte de um programa de comunicação e informação que incentive os servidores a participarem continuamente das ações indicadas no planejamento. 
O PGRS do Campus Trindade foi elaborado também em consonância com as ações e metas estabelecidas pela Lei 14.248, de 29 de julho de 2012, que instituiu a Política Estadual de Resíduos Sólidos do Estado de Goiás, cujo Plano de Gerenciamento ainda está em fase de desenvolvimento. De acordo com a regulamentação, a prevenção da poluição, a eliminação, ou, pelo menos a redução da geração de resíduos na fonte, a recuperação ambientalmente segura de materiais ou de energia dos resíduos ou produtos descartados, o tratamento ambientalmente seguro dos resíduos, a disposição final ambientalmente segura dos resíduos remanescentes e a recuperação das áreas degradadas pela disposição inadequada dos resíduos consistem nas diretrizes a serem observadas na gestão dos resíduos sólidos pelo Estado.

\subsection{Diretrizes do Gerenciamento de Resíduos Sólidos do Campus Trindade}

Um Plano de Gerenciamento de Resíduos Sólidos se faz importante por sistematizar riscos e reduzir custos associados à gestão de resíduos sólidos, assegurando que todos os resíduos gerados sejam geridos de maneira segura, desde a sua geração até a destinação final. Assim, este tópico apresentará os eixos temáticos nos quais o PGRS para o Campus Trindade será definido. São eles: Geração; Segregação; Reutilização; Coleta, Transporte Interno e Armazenamento; e Destinação Final. Estas etapas foram estabelecidas em consonância com a PNRS e com base nos PGRS do MEC, PUC-Rio, UFPA e UFSC, além de terem sido abordados no questionário de diagnóstico do manejo de resíduos sólidos no Campus Trindade. 


\subsubsection{Geração}

Por meio do estudo da composição gravimétrica dos resíduos gerados na unidade, foi possível estabelecer uma média de lixo diário gerado pelo campus, que foi de $16,72 \mathrm{~kg} / \mathrm{dia}$, e também per capita de $0,047 \mathrm{~kg} /$ pessoa. Foi possível observar ainda, que a maior parte dos resíduos sólidos gerados no Campus Trindade é decorrente das atividades de alimentação dos alunos e servidores da Instituição, o que exigirá da comissão responsável pela execução do gerenciamento de resíduos sólidos da unidade, atenção diferenciada para esta situação, levando-se em conta a instalação de refeitório no futuro. Também o setor administrativo deverá considerar tal informação, na hora de licitar serviços de lanchonete. Sugere-se que a adoção de ações sustentáveis e materiais recicláveis estejam sejam previstos nos contratos licitatórios.

Seguindo a ordem de prioridade para um modelo de gestão de resíduos sólidos, segundo estabelece a Lei $\mathrm{n}^{\circ} 12.305$, nesta primeira etapa de um plano de gerenciamento de resíduos sólidos o ideal é priorizar a não geração de resíduos, seguido da redução, reutilização e reciclagem. Dessa forma, esta será a ordem adotada pelo Plano elaborado para o Campus Trindade. Por isso, será de extrema importância "enfatizar o conceito de repensar, tanto na forma que produzimos e consumimos os recursos como no modo de gerenciar o problema gerado" (GOMES, 2012).

\subsubsection{Descarte e segregação}

Em um sistema de coleta seletiva, cada material reciclável deve ser descartado em coletor específico, com cores diferentes para os diferentes tipos de resíduos, de acordo com a Resolução Conama n 275/01, de 25 de abril de 2001. Essa resolução estabelece o código de 
cores a ser adotado na identificação de coletores, conforme mostra a Figura 13. Porém, a análise do diagnóstico, associada às orientações passadas pelo Ministério do Meio Ambiente por meio de capacitações realizadas pela $\mathrm{A} 3 \mathrm{P}$, sugerem que, nesse primeiro momento, o descarte seja realizado em três categorias: materiais recicláveis, orgânicos e não recicláveis.

Figura 13 - Identificação das cores dos coletores segundo Resolução Conama nº 275/01

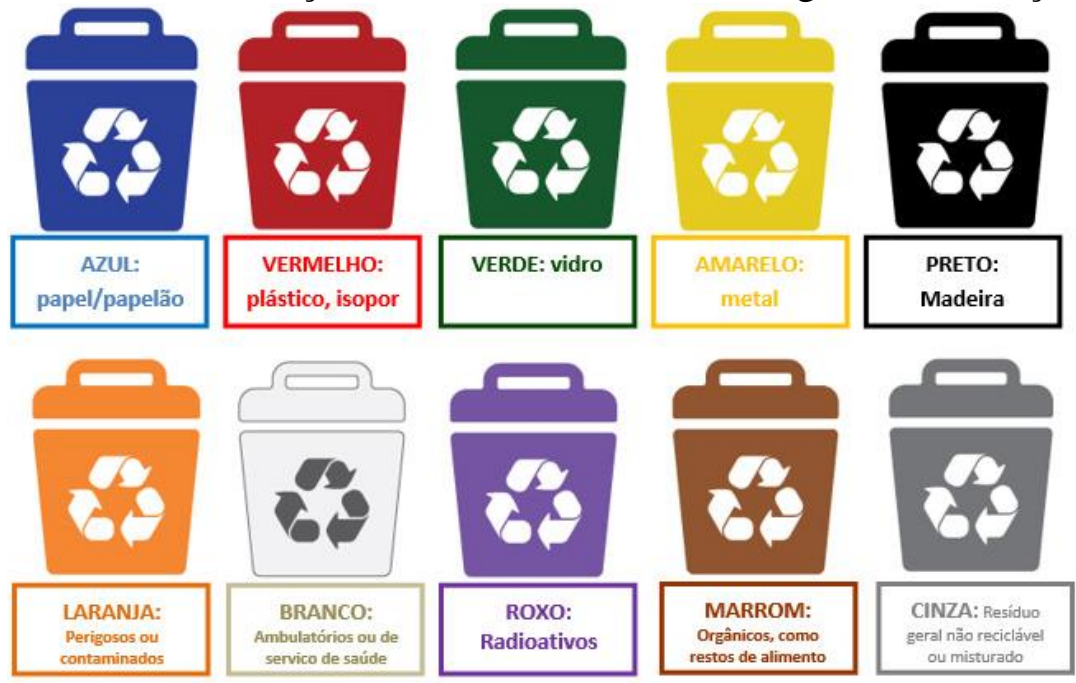

Fonte: www.reciclaambientalsc.com.br/a-importancia-da-reciclagem/.

Os coletores devem ser colocados em locais estratégicos de modo a facilitar e incentivar a coleta seletiva. Foi observado que, atualmente, existe um número alto de coletores espalhados pelo pátio e com capacidade volumétrica acima da necessária. Tal fato foi percebido uma vez que, as sacolas pesadas durante a caracterização volumétrica eram recolhidas bem antes de atingirem sua capacidade máxima. Algumas foram pesadas praticamente vazias, o que aponta para ocorrência de mau aproveitamento do material de limpeza.

Sabe-se que, por se tratar de órgão público, na compra dos coletores prevalecerá aquele com menor preço. Porém, uma série de medidas pode ser tomada para que se obtenha um melhor custo-benefício na aquisição desse material. Alguns pontos importantes devem ser levados em consideração como: tamanho e capacidade volumétrica do coletor; ergonomia 
adequada para fácil manuseio; coloração conforme normatização e sinalização de fácil entendimento (GOMES, 2012).

Em relação à Segregação, como foi relatado no diagnóstico descrito no capítulo 4, existe uma campanha de incentivo às ações sustentáveis e, também, um projeto de quantificação de resíduos sólidos gerados pela unidade, porém eles não se mostram eficazes no que tange a separação do material passível de reciclagem. Por isso esta etapa deverá ser executada de maneira criteriosa e associada ao correto descarte dos resíduos, uma vez que estas duas ações evitam a mistura de resíduos incompatíveis e reações químicas indesejadas, aumentando a possibilidade de reutilização, reciclagem e segurança no manejo realizado nas etapas seguintes. O descarte incorreto, por exemplo, de um resíduo perigoso, pode acarretar na contaminação de outros materiais, dificultando sua gestão e aumentando os custos a ele associados, além de ser prejudicial ao meio ambiente e a comunidade no qual está inserido. $\mathrm{O}$ Quadro 5 apresenta uma relação de materiais recicláveis e não recicláveis.

Quadro 5-Exemplos de materiais recicláveis e não recicláveis

\begin{tabular}{|c|c|}
\hline RECICLÁVEL & NÃO RECICLÁVEL \\
\hline Papel & Papel \\
\hline $\begin{array}{l}\text { Papelão } \\
\text { Jornais e revistas } \\
\text { Folhas de caderno } \\
\text { Formulários de computador } \\
\text { Caixas em geral } \\
\text { Aparas de papel } \\
\text { Fotocópias } \\
\text { Envelopes } \\
\text { Provas } \\
\text { Rascunhos } \\
\text { Cartazes velhos } \\
\text { Papel de fax }\end{array}$ & $\begin{array}{l}\text { Etiqueta adesiva } \\
\text { Papel carbono } \\
\text { Fita crepe } \\
\text { Papéis sanitários } \\
\text { Papéis metalizados } \\
\text { Papéis parafinados } \\
\text { Papéis plastificados } \\
\text { Papéis sujos } \\
\text { Guardanapos } \\
\text { Bitucas de cigarros } \\
\text { Fotografias }\end{array}$ \\
\hline Plástico & Plástico \\
\hline $\begin{array}{l}\text { Garrafa PET } \\
\text { Isopor } \\
\text { Embalagem de material de limpeza } \\
\text { Embalagem de margarina } \\
\end{array}$ & $\begin{array}{l}\text { Cabo de panelas } \\
\text { Mistura de papel, plásticos e metais. } \\
\text { Embalagem de biscoito }\end{array}$ \\
\hline
\end{tabular}


(Continuação Quadro 5 - Exemplos de materiais recicláveis e não recicláveis)

\begin{tabular}{|l|l|}
\hline \multicolumn{1}{|c|}{ Metal } & Metal \\
\hline $\begin{array}{c}\text { Lata de óleo } \\
\text { Enlatados (sardinha, salsicha) } \\
\text { Lata de leite em pó } \\
\text { Lata de alumínio } \\
\text { Sucatas de reformas }\end{array}$ & $\begin{array}{l}\text { Esponjas de aço } \\
\text { Canos }\end{array}$ \\
\hline $\begin{array}{l}\text { Vidro } \\
\text { Embalagens } \\
\text { Garrafas de vários formatos }\end{array}$ & \\
Copos & Vidro \\
\hline
\end{tabular}

Fonte: pesquisa da autora.

\subsubsection{Acondicionamento e Identificação}

Todo o processo de acondicionamento dos resíduos sólidos separados deve ser realizado em consonância com o previsto na normativa NBR 9191/2000. Prioritariamente eles devem ser embalados em sacos ou recipientes que sejam capazes de manter o conteúdo armazenado em segurança, ou seja, sem vazamentos, resistentes a impactos e rupturas, além de serem compatíveis com a geração diária de cada tipo de resíduo.

Quadro 6 - Modelo de identificação utilizado no acondicionamento dos resíduos

\begin{tabular}{|c|l|}
\hline Grupo & \multicolumn{1}{c|}{ Orientação } \\
\hline A & $\begin{array}{l}\text { é identificado pelo símbolo de substância } \\
\text { infectante constante na NBR-7500 da ABNT, } \\
\text { com rótulos de fundo branco, desenho e } \\
\text { contornos pretos. }\end{array}$ \\
\hline B & $\begin{array}{l}\text { é identificado através do símbolo de risco } \\
\text { associado, de acordo com a NBR 7500 da } \\
\text { ABNT e com discriminação de substância } \\
\text { química e frases de risco. }\end{array}$ \\
& $\begin{array}{l}\text { é representado pelo símbolo internacional de } \\
\text { presença de radiação ionizante (trifólio de cor } \\
\text { magenta) em rótulos de fundo amarelo e } \\
\text { contornos pretos, acrescido da expressão } \\
\text { REJEITO RADIOATIVO. }\end{array}$ \\
\hline
\end{tabular}


(Continuação Quadro 6 - Modelo de identificação utilizado no acondicionamento dos resíduos)

\begin{tabular}{|ll|}
\hline E & é identificado pelo símbolo de substância \\
& infectante constante na NBR 7500 da ABNT, \\
& com rótulos de fundo branco, desenho e \\
& contornos pretos, acrescido da inscrição de \\
& RESÍDUO PERFUROCORTANTE, \\
& indicando o risco que apresenta o resíduo. \\
\hline
\end{tabular}

Fonte: UFPA, 2008

Outra medida importante é a identificação do material acondicionado, que "consiste no conjunto de medidas que permite o reconhecimento dos resíduos contidos nos sacos e recipientes, fornecendo informações ao correto manejo dos RSS" (UFPA, 2008). O Quadro 12 mostra o modelo de identificação adotado pela Universidade Federal do Pará. A identificação poderá ser feita por meio de adesivos, ou outro método, desde que estes sejam preservados durante o manuseio dos sacos ou recipientes. Esse processo deverá respeitar os parâmetros definidos pela NBR 7500, que trata da identificação para o transporte terrestre, manuseio, movimentação e armazenamento de produtos.

\subsubsection{Coleta e Tratamento}

A coleta se dá pelo processo de transferência dos resíduos, acondicionados e identificados, do local da geração para o armazenamento temporário e deste para o armazenamento externo. Para que este sistema funcione é necessário que se estabeleça uma grade de horários que esteja de acordo com as principais atividades de geração de RS decorrentes das ações de ensino, pesquisa e extensão da unidade.

Este processo deve ser realizado em recipientes próprios para este fim. É aconselhável que estes equipamentos sejam constituídos de material rígido, lavável, impermeável, provido de tampa articulada e rodas revestidas de material que reduza o ruído. Caso o recipiente seja desprovido de rodas, deve-se observar os limites de carga permitidos para o transporte pelos 
trabalhadores, conforme normas reguladoras do Ministério do Trabalho e Emprego (NR 17, que trata da Ergonomia).

Já o tratamento é o processo, método ou técnica responsável pela redução ou eliminação dos riscos de contaminação, acidentes ocupacionais ou de danos ao meio ambiente apresentados por determinados tipos de resíduos sólidos. O tratamento deve ser realizado por profissional qualificado no próprio local gerador, ou em outro espaço, desde que sejam respeitadas as condições de segurança para o transporte entre o estabelecimento gerador e o local de tratamento. Cabe destacar, que este processo nunca deverá ser realizado no espaço destinado ao armazenamento temporário.

\subsubsection{Armazenamento Temporário e Transporte Interno}

Os resíduos coletados devem ser direcionados para o local de armazenamento temporário, que consiste em um espaço destinado ao abrigo do material que já passou por separação, funcionando como um local de transferência interna. É aconselhável que este espaço possua pisos e paredes lisas e laváveis, para melhor higiene do local. Além disso, o piso deve ser resistente ao tráfego dos recipientes coletores. O armazenamento dos resíduos deve ser realizado em recipientes próprios de acondicionamento e nunca com disposição direta dos sacos sobre o piso (UFPA, 2008). Esses recipientes serão utilizados para realização do transporte interno, que destinará os resíduos para o local de armazenamento externo.

\subsubsection{Armazenamento e Transporte Externos}

O local de armazenamento externo tem como principal função a alocação dos resíduos gerados na Instituição a serem encaminhados para a destinação final. Este material deve ficar 
localizado em espaço exclusivo, com acesso facilitado para veículos coletores. Para definição deste espaço deve-se levar em conta também a massa total de resíduos gerada pela Instituição, considerando porém, as quantidades direcionadas para reciclagem e/ou compostagem, caso existam. É importante destacar que "no armazenamento externo não é permitida a manutenção dos sacos de resíduos fora dos recipientes ali estacionados. Deverá se definir o local para armazenamento externo, bem como a forma de acesso" (UFPA, 2008, p.26).

Já o transporte externo é definido pelo processo de remoção dos resíduos acomodados neste local e direcionamento para unidade de tratamento ou disposição final, de acordo com as orientações dos órgãos de limpeza urbana e legislações específicas.

\subsubsection{Disposição Final}

A disposição final dos resíduos sólidos gerados pela Administração Pública Federal deve priorizar a minimização dos impactos ambientais e promoção da inclusão socioeconômica de catadores de materiais reutilizáveis ou recicláveis, por meio da Coleta Seletiva Solidária (Decreto $n^{\circ}$ 5.940/2006). Deve-se levar em conta também, a manutenção de contratos que incluem o processo de logística reversa. "Ao contratar o fornecimento de determinado material, é importante que sejam previstos em contrato que a empresa recolha o resíduo gerado e garanta a destinação ambientalmente adequada e seu retorno ao ciclo produtivo" (MMA, 2015, p. 54). 


\subsection{Procedimentos para implantação do Plano de Gerenciamento de Resíduos Sólidos do IF Goiano - Campus Trindade}

No Instituto Federal Goiano, bem como no Campus Trindade, não existe uma política ambiental institucionalizada, ou seja, aprovada pelo Conselho Superior da Instituição. O que existem são ações difusas desenvolvidas por meio de comissões, através de programas institucionais. Neste âmbito, um dos maiores problemas é a falta de envolvimento e interesse tanto dos servidores em implantar e aceitar uma nova cultura, quanto dos gestores em assumir e apoiá-la como tal - a adoção de ações sustentáveis deve partir da reitoria, com apoio da direção do campus. Assim, a elaboração de um PGRS a que se propõe esta pesquisa não visa oferecer um modelo engessado para pronta aplicação, mas sim mostrar possibilidades de atuação ao fomentar a Instituição com dados que possam ser utilizados em favor da realidade estudada.

Neste capítulo estão propostas ações que foram elaboradas com o objetivo de viabilizar a implantação do plano de gerenciamento de resíduos sólidos no IF Goiano Campus Trindade. Estas atividades foram desenvolvidas a partir do diagnóstico exposto no capítulo 4, associadas às diretrizes estabelecidas no tópico anterior e à legislação vigente. Considerou-se também, a experiência decorrente das ações da Agenda Ambiental da Administração Pública (A3P) já existentes no Instituto e que puderam ser aplicadas como modelo na realidade estudada. A implantação do PGRS no Campus Trindade visa apresentar alternativas viáveis para eliminar ou minimizar problemas decorrentes da disposição inadequada dos resíduos sólidos na unidade. 


\subsubsection{Recursos Humanos e Orçamentários}

Inicialmente, para correto funcionamento de um plano de gerenciamento de resíduos sólidos, conforme prevê a Lei $\mathrm{n}^{\mathrm{o}} 12.305$ e também como foi observado nos trabalhos utilizados como referência para consecução desta pesquisa, faz-se necessário criar um Grupo Gestor dos Resíduos Sólidos do Campus Trindade. É recomendável que os responsáveis pela execução do Plano sejam nomeados por meio de portaria, documentando assim, as competências, responsabilidades e obrigações da equipe de trabalho. É importante que este grupo seja composto por representantes das áreas ambientais e de administração, além de servidores que possuam afinidade com a área, uma vez que estarão comprometidos com o desenvolvimento diário das ações do Plano, como capacitação, campanhas e monitoramento constante das atividades previstas. Outra possibilidade é incluir projetos de extensão com esta temática, recrutando assim professores e alunos interessados na área ambiental.

Cabe destacar que a própria comissão responsável pelo gerenciamento do Plano também deva passar por processos de formação e capacitação. Cursos com essa finalidade são oferecidos pelo Ministério do Meio Ambiente, por meio da Rede A3P. Para aderir a essa Rede basta solicitar, por meio do e-mail a3p@mma.gov.br ${ }_{2}$ o cadastro informando os dados: nome, órgão, setor, e-mail, telefone e endereço. Uma equipe melhor capacitada decorre em decisões mais autônomas e eficientes para a implantação de suas ações. São atribuições deste grupo gestor:

Viabilizar e facilitar o acesso a todas informações sobre o tema dos resíduos de forma organizada e centralizada; Oferecer capacitação para a realização de planos e diagnósticos de resíduos sólidos nos demais Câmpus, bem como para o gerenciamento adequado de todas as categorias de resíduos (tanto para servidores, quanto funcionários, acadêmicos e docentes); Promover programas de educação ambiental para a comunidade universitária; Organizar encontros, palestras e outros tipos de eventos que auxiliem na conscientização acerca da problemática ambiental ligada a resíduos; Monitorar o Gerenciamento de resíduos sólidos da instituição, entre outras. (BITTENCOURT, 2014, p. 97). 
Além disso, outra possibilidade decorrente da consolidação de um grupo gestor é a instituição futura de um setor específico para a Gestão de Resíduos Sólidos. Neste setor seriam centralizadas e organizadas todas as informações quali e quantitativas referentes ao gerenciamento de resíduos sólidos na unidade. De acordo com Bittencourt (2014), esta maneira de sistematizar o trabalho é importante por facilitar o controle com gastos, caso exista, bem como a auxiliar na realização de diagnósticos de resíduos para a revisão dos planos. No organograma geral do IF Goiano, em nível institucional, foi criado, em 2015, o Núcleo de Sustentabilidade e Gestão Ambiental. Apesar de estar previsto no Plano de Desenvolvimento Institucional (PDI) do Instituto, o Núcleo ainda não possui membros e, por isso, ainda não está em atividade. Segunda a pró-reitoria de Desenvolvimento Institucional, não há previsão para composição do Núcleo, nem para o início das ações.

A fim de institucionalizar e legitimar as ações referentes ao gerenciamento de resíduos sólidos há de se considerar recursos financeiros específicos e constantes para esta finalidade. A instituição pode criar uma rubrica no seu orçamento que contemple essas atividades e que faça parte da política administrativa Institucional, uma vez que algumas ações previstas no Plano exige algum investimento. Assim como foi mostrado nos PGRSs da UFPA e Campus Gávea da PUC-Rio, questões financeiras podem ser tratadas com o envolvimento da Reitoria.

\subsubsection{Educação Ambiental e Conscientização}

Criado o grupo responsável pelo gerenciamento dos resíduos sólidos no Campus Trindade, o principal desafio será a conquista de uma postura socioambiental entre a comunidade acadêmica da Instituição. Isso porque, apesar do índice de consciência ambiental da unidade ter indicado que alunos e servidores possuem potenciais traços de consciência ambiental, o grau de consumo consciente mostrou que esse público possui fracos traços de 
consumo ecologicamente correto. Esse quadro apresenta a fragilidade de uma consciência ambiental consolidada, expondo a necessidade primeira de se promover ações de educação ambiental.

Nesta etapa, "deve-se realizar uma educação ambiental que não apenas transmita informações e conteúdos, mas propicie aprendizados e mudanças culturais" (BITTENCOURT, 2014, p. 104). A educação ambiental é necessária para que alunos e servidores assumam a corresponsabilidade perante ao resíduo gerado, ou seja, para que eles, enquanto geradores entendam que são responsáveis por todo processo, desde a geração do seu resíduo, até o tratamento e disposição final. Todo o processo de educação ambiental deverá conscientizar a comunidade acadêmica para a não geração, redução, reutilização, reciclagem, tratamento e disposição final adequada dos resíduos sólidos gerados na Instituição, respeitando assim, a ordem hierárquica prevista na Lei $\mathrm{n}^{\circ} 12.305$.

Por ser uma importante ação dentro da Instituição, a campanha "Campus Trindade, eu amo, eu cuido", pode ser utilizada como uma importante ferramenta de conscientização ao adotar um viés mais ambiental, tendo como uma de suas vertentes o gerenciamento de resíduos sólidos. Outra relação importante nesta fase é o envolvimento da Assessoria de Comunicação Social (Ascom), que pode agir de forma crucial no desenvolvimento de peças, ações e campanhas em prol do gerenciamento de RS.

Uma ferramenta que pode se mostrar eficiente é envolver a participação dos alunos em todo processo de criação de uma campanha de conscientização, por exemplo, e não só como agentes receptores, gerando assim, envolvimento de toda comunidade acadêmica. Uma estratégia é envolver, se possível, cada turma de acordo com seu curso. São ações de educação ambiental que podem ser adotadas pelo Campus Trindade: 
I. Inserção da temática do gerenciamento de resíduos na programação da Semana Pedagógica e nos programas de integração dos novos professores;

II. Inserção da temática do gerenciamento de resíduos nas ações de extensão e Semana de Ciência e Tecnologia;

III. Criação de uma ação educativa em parceria com a Assessoria de Comunicação Social (campanha, criação de material e veículo específico);

IV. Implementação de programas de capacitação da comunidade acadêmica para o manejo correto de resíduos sólidos;

V. Realização de palestras e ações com parceiros (Prefeitura e Estado, por exemplo);

VI. Promover a capacitação dos servidores terceirizados, principalmente da equipe responsável pela limpeza;

VII. Promover a sustentabilidade nos eventos da Instituição;

VIII. Fazer um acordo para coleta dos resíduos recicláveis por uma cooperativa de catadores.

\subsubsection{Diagnóstico}

O diagnóstico compreende o estudo da situação da instituição em relação aos resíduos sólidos, fornecendo dados necessários para a implantação de um plano de gerenciamento (UFPA, 2008). Deve abordar, basicamente, o seguinte conteúdo: levantamento das atividades, caracterização e quantificação dos resíduos, coleta, transportes interno e externo e disposição final. Por apresentar um cenário referente a um dado momento, esse diagnóstico deve ser realizado sempre que o PGRS for revisado.

É importante também, que todas as informações registradas nesta etapa sejam arquivadas a fim de se constituir uma base de dados, para que se possa comparar dados e 
aprimorar indicadores para monitoramento e avaliação das ações implantadas. O diagnóstico da pesquisa em questão foi realizado por meio da identificação dos procedimentos referentes à geração de resíduos sólidos, à identificação dos graus de consciência ambiental e consumo consciente dos servidores e alunos e caracterização dos resíduos sólidos produzidos no Campus Trindade.

\subsubsection{Implantação da coleta seletiva}

Concomitante ao processo de conscientização, que inclusive pode ser orientado com vistas a incentivar a correta separação do resíduo, a implantação da coleta seletiva é uma das principais medidas a ser adotada pelo Campus Trindade, segundo mostrou diagnóstico apresentado no capítulo 4. Apesar de já existir algumas ações em prol da segregação de resíduos, pode-se considerar que a coleta será implantada desde seu início, passando pelo processo de conscientização, aquisição de coletores e containers, disposição dos mesmos na unidade, capacitação da equipe de limpeza e correta disposição final.

A partir da caracterização dos resíduos sólidos e considerando que o material orgânico corresponde a $68 \%$ do total gerado no Campus Trindade sugere-se a separação destes em: orgânicos, recicláveis e não recicláveis. Seguindo esta orientação, será necessária a aquisição de coletores nas cores marrom, para orgânicos, cinza, para resíduo geral não reciclável e verde para recicláveis. Essas cores seguiram a padronização segundo estabelece a Resolução CONAMA 275/2001, exceto pela cor verde designada para resíduos recicláveis. Como para este grupo não existe uma cor padrão, sugeriu-se o verde por já ser utilizado em outros campi do Instituto. É importante que os coletores sejam identificados por escrito com o tipo de resíduo que receberá. No caso de morosidade na compra desses novos recipientes, uma alternativa é a confecção de adesivos das cores correspondente a cada resíduo, por exemplo: 
para material reciclável, adesivo escrito Reciclável, com fundo verde. Essas peças devem ser produzidas pela Assessoria de Comunicação Social.

Nas salas de aula os coletores podem ser destinados ao descarte de recicláveis e não recicláveis. Considerando que os alunos possuem horário para sair da sala e efetuarem suas refeições (intervalo entre aulas e troca de turno), o diagnóstico mostrou que os resíduos orgânicos coletados em sala de aula são praticamente nulos. Porém, a atenção com descarte correto dos resíduos no seu respectivo coletor deve ser bem reforçada no processo de conscientização. Já para as salas dos setores administrativos, os pontos de descarte podem ser compostos pela combinação de três coletores: recicláveis, não recicláveis e orgânicos. Isso porque, devido à intensa rotina de trabalho muitos servidores realizam refeições em seu ambiente de trabalho.

Outra ação a ser implantada refere-se a redução, e posterior não utilização, de copos plásticos. Para tanto será necessário desenvolver um trabalho de conscientização que incentive alunos e servidores a utilizarem garrafas ou squeezes próprios, de modo a reduzir a disponibilização de copos plásticos de maneira gradativa. No caso dos servidores pode ser sugerida ainda a utilização de canecas ou copos. O Instituto possui uma licitação de comunicação visual e serviços gráficos, gerida pela Coordenação-geral de Comunicação Social e Eventos da Instituição, na qual prevê a produção de squeeze em material reciclado. Porém, a partir de 2016, esse material só poderá ser solicitado mediante justificativa de eventos esportivos.

Tão importante quanto segregar, é não haver a mistura desses resíduos nas demais etapas do gerenciamento, por isso deverá ocorrer um processo criterioso de capacitação da equipe responsável pela limpeza, bem como disponibilização de infraestrutura adequada para que o processo seja executado de maneira bem sucedida. Para tanto é aconselhável que se construa uma estação para armazenamento temporário, que permita a correta disposição dos 
resíduos até que estes sejam encaminhados para o armazenamento externo. A orientação é que esta demanda seja encaminhada para o Núcleo de Elaboração e Gerenciamento de Projetos de Engenharia e Arquitetura, da Coordenação-Geral de Desenvolvimento de Infraestrutura do Instituto, uma vez que estão trabalhando no projeto de expansão do campus.

O armazenamento externo deverá contar com a aquisição de outro container, para que a disposição do material separado seja feita de maneira correta. Uma vez que o contêiner já existente é verde, conforme mostra Figura 14, o novo a ser adquirido poderá ser da cor cinza. É importante também que estes coletores sejam identificados por escrito com o tipo de resíduo que receberá (Recicláveis e Não Recicláveis). O outro container a ser adquirido pode ter a mesma capacidade do atual.

Figura 14 - Container destinado ao armazenamento externo

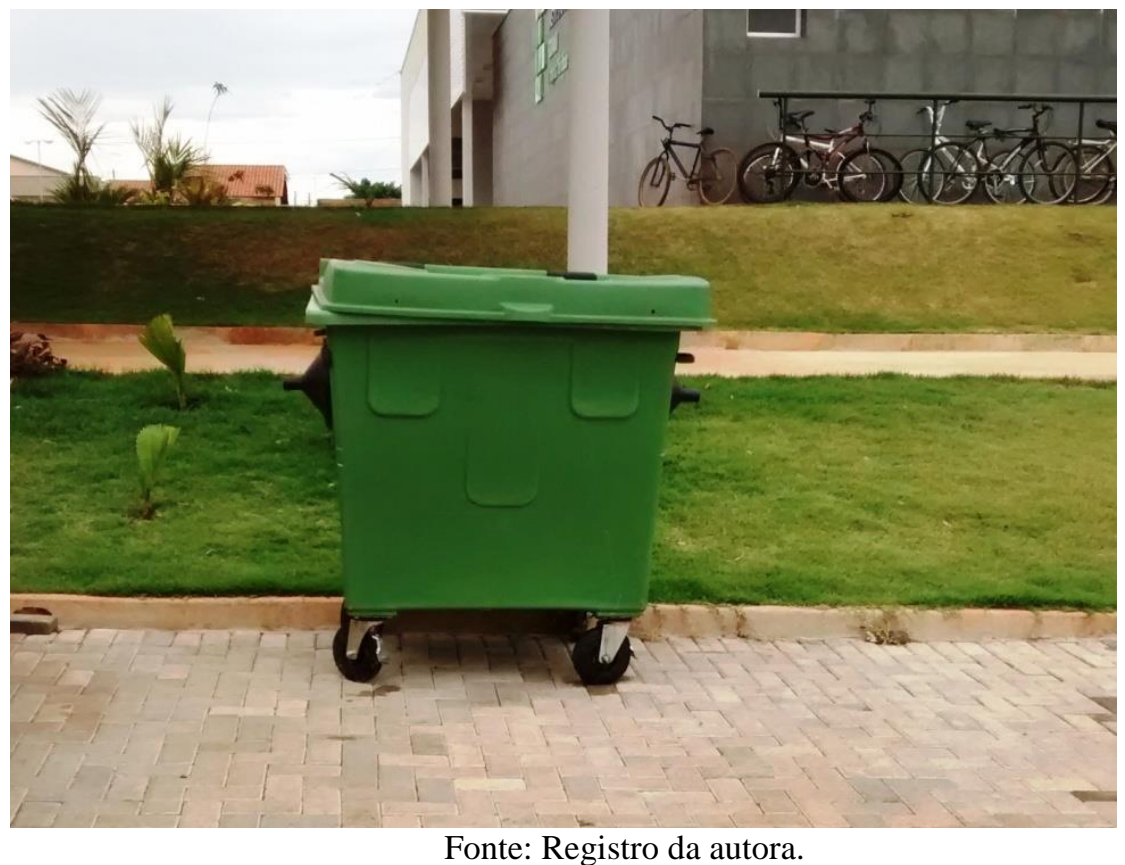

A coleta seletiva será implantada também com o objetivo de atender ao Decreto 5.940/06, que exige de órgãos e entidades de administração pública federal direta e indireta a realização da coleta seletiva solidária. Dessa forma, os resíduos passíveis de reciclagem 
gerados no Campus Trindade deverão ser encaminhados para associações e cooperativas de catadores de material recicláveis. Deve-se formar uma comissão ou equipe específica para implantar e supervisionar a separação dos resíduos recicláveis descartados na fonte geradora, além de pesar e certificar sua destinação para as cooperativas ou associações de materiais recicláveis. Para se submeterem à coleta seletiva solidária instituída em órgãos e entidades da administração pública federal as cooperativas devem atender aos seguintes requisitos:

I - estejam formal e exclusivamente constituídas por catadores de materiais recicláveis que tenham a catação como única fonte de renda; II - não possuam fins lucrativos; III - possuam infra-estrutura para realizar a triagem e a classificação dos resíduos recicláveis descartados; e IV - apresentem o sistema de rateio entre os associados e cooperados. (BRASIL, 2006).

Em contato com a prefeitura do município de Trindade e em pesquisa realizada por meio da internet, encontrou-se apenas a Cooperativa de Trabalho Dos Catadores de Material Reciclável de Trindade (Coopertrin). A Cooperativa foi implantada em Trindade pela prefeitura municipal, em parceria com a Universidade Federal de Goiás (UFG) e funciona com o apoio da Secretaria Municipal de Meio Ambiente (Semma). Segundo a responsável pela administração e logística da cooperativa, Izabelita Basílio, a Coopertrin trabalha com diversos tipos de materiais, como papel, papelão, plástico, alumínio, sucatas de ferro e vidro (garrafas).

Quando não há coleta seletiva na cidade ou as cooperativas presentes no município não atendam aos requisitos exigidos pelo decreto, a Secretaria de Recursos Hídricos e Ambiente, do MMA, recomenda que o gerador busque nas cidades vizinhas cooperativas ou empresas recicladoras. Assim, outra alternativa é buscar cooperativas na cidade de Goiânia. O Anexo C apresenta uma lista de cooperativas de trabalhadores de materiais recicláveis disponibilizada pela prefeitura de Goiânia. Caso haja mais de uma associação interessada, a Instituição deverá promover seleção de acordo com as normas estabelecidas pelo Decreto 5.940/2006. Todo processo deverá ser amplamente divulgado de modo a assegurar a lisura e 
igualdade de participação das associações e cooperativas de catadores de materiais recicláveis.

No que se refere à destinação final dos resíduos orgânicos, que representam quase $70 \%$ do total gerado e por ser este, basicamente, composto por restos de alimentos, torna-se viável a implantação de um sistema de compostagem. "Essa ação traria a redução dos custos com armazenagem e destinação final, além de acarretar em benefícios ambientais e sociais" (GOMES, 2012). Além disso, por meio da compostagem será possível aproveitar estes resíduos como adubo para jardins e demais áreas verdes da unidade, podendo ser também destinado a outros campi da Instituição, dependendo da quantidade produzida. Esta atividade pode ainda ser contemplada como extensão prática da sala de aula, uma vez que a manutenção poderá ser viabilizada por alunos bolsistas, sob a supervisão de professores da área. Os campi Ceres e Iporá, por exemplo, têm experiências com projetos de compostagem e podem fornecer informações sobre a adoção desta técnica. Na Universidade de Santa Catarina também é realizado tal método:

\begin{abstract}
a compostagem termofílica realizada na UFSC, é um processo controlado de decomposição aeróbia de resíduos orgânicos, realizada por microorganismos, principalmente fungos e bactérias. Os principais fatores, determinantes no processo, são os microorganismos aeróbicos, controle da umidade, aeração das leiras, controle da temperatura, relação carbono/nitrogênio do material de origem e dimensão adequada da leira. Todos esses elementos são indispensáveis para o processo de decomposição da matéria orgânica, dentro da leira fazendo com que as temperaturas atinjam entre $55^{\circ} \mathrm{C}$ a $65^{\circ} \mathrm{C}$. Isso faz com que ocorra a eliminação de patógenos e sementes de plantas daninhas, resultando em um fertilizante orgânico de alta qualidade e de baixo custo de produção. (JULLIATO; CALVO; CARDOSO, 2011, p. 183).
\end{abstract}

Já em relação ao descarte, coleta e destino final dos resíduos gerados por laboratórios, não foi possível prever os tipos de resíduos gerados, uma vez que a unidade não conta com laboratórios equipados. Segundo a coordenação Pedagógica, como os equipamentos ainda não foram instalados e nem, ao mesmo, chegaram na Instituição, alguns laboratórios deram lugares a salas administrativas, como é o caso do laboratório de línguas que virou sala da 
coordenação pedagógica. Nem a coordenação do Campus Trindade nem a Coordenação-Geral de Desenvolvimento de Infraestrutura do Instituto conseguiram prever a data de instalação destes laboratórios.

\subsubsection{Descarte de materiais que exigem logística reversa}

Um sistema de logística reversa deverá ser implementado no Campus Trindade com o objetivo de promover procedimentos e meios que viabilizem a coleta e a restituição dos resíduos sólidos ao setor empresarial, para reaproveitamento, em seu ciclo ou em outros ciclos produtivos, ou outra destinação final ambientalmente adequada. Atualmente, são resíduos passíveis de logística reversa no Campus Trindade: pilhas, baterias, lâmpadas, óleos lubrificantes e seus recipientes. Os pneus já são deixados na oficina, como parte do contrato, na hora da troca, tornando responsabilidade do estabelecimento a destinação final. Já os eletrônicos são destinados a doações.

Para operacionalizar a logística reversa, a PNRS prevê instrumentos que visam distribuir as responsabilidades entre cada uma das partes do setor produtivo (MMA, 2014a). Essas ferramentas são: a) acordo setorial; b) regulamentos expedidos pelo poder público (decreto); e c) termos de compromisso. Possuindo natureza contratual, o acordo setorial consiste nos atos firmados entre o poder público e os fabricantes, importadores, distribuidores ou comerciantes, visando à implantação da responsabilidade compartilhada pelo ciclo de vida do produto, podendo ter abrangência nacional, regional, estadual ou municipal.

Quando não existe um acordo setorial, é possibilidade se estabelecer a logística reversa diretamente por decreto. Nesse caso é necessário que o processo seja precedido por uma consulta pública. Se não houver acordo setorial ou decreto, ou se a fixação de 
compromissos e metas for mais exigente do que o previsto em acordo setorial ou regulamento específico a alternativa passa a ser o termo de compromisso (MMA, 2014a).

\subsubsection{Elaboração de uma Política Institucional Ambiental}

Entende-se por política ambiental como o compromisso da administração com o seu desempenho ambiental, por meio da formalização de suas intenções, princípios gerais e objetivos e metas ambientais (ABNT, 1996). Assim, embora as ações a serem implantadas sejam iniciais, literaturas recomendam que, para que as atividades de gerenciamento sejam eficientes e legitimadas, toda experiência acumulada desde o começo deve ser articulada e formatada na forma de Política Institucional Ambiental e, consequentemente, abrangendo a gestão e o gerenciamento de resíduos sólidos (BITTERNCOURT, 2014).

A Política Ambiental constitui a base sobre a qual a organização estabelece suas metas e objetivos ambientais, assim o PGRS elaborado e aplicado ao Campus Trindade pode e deve servir de modelo para que os demais campi possam desenvolver os seus próprios projetos de acordo com cada realidade e assim institucionalizar o gerenciamento de resíduos sólidos e demais práticas ambientais. Assim é tão importante, quanto necessário, que a dimensão ambiental seja contemplada no planejamento da administração, integrando o Plano de Desenvolvimento Institucional (PDI), que é o documento máximo da Instituição Federal de Ensino Superior (Ifes). Almeida (2000) destaca a importância da formalização de uma política desta natureza, bem como a necessidade dela estar em consonância com outras políticas e normas internas da instituição, para que se obtenha uma melhoria contínua do seu desempenho ambiental.

Além de legitimar a prática ambiental, uma política ambiental reflete o comprometimento da alta gestão com o atendimento aos requisitos legais aplicáveis e com a 
adoção de ações socioambientais pela Instituição. Por isso, para que uma política institucional funcione é necessário que toda administração se envolva e assuma as ações referentes à implementação desta política. "É compromisso de toda instituição reduzir os impactos ambientais nos processos, produtos e serviços e certificar a contratação de fornecedores e prestadores de serviços que também tenha o mesmo comprometimento" (JULLIATO; CALVO; CARDOSO, 2011). No âmbito das causas ambientais, isso influencia não só na postura interna adotada por servidores e alunos, no caso do IF Goiano - Campus Trindade, como também agrega valor à imagem externa da unidade perante a sociedade.

Em relação à manutenção da política ambiental, a NBR ISO 14.001, que especifica os requisitos relativos a um sistema da gestão ambiental, orienta a implementação e aprimoramento contínuo de um SGA para assegurar conformidade com a política ambiental definida para instituição. Dessa forma, sugere-se que trabalhos iniciais no sentido de elaborar uma política institucional ambiental, com foco inicial nos resíduos sólidos, e a implementação de um SGA, composto por uma equipe multidisciplinar, sejam realizados no sentido de oferecer uma base a legitimação das ações implementadas a partir do PGRS.

\subsubsection{Redução}

Trata-se de repensar a necessidade de consumo de materiais e redução da geração de resíduos por parte dos servidores e alunos do Campus Trindade, entendendo a redução como o uso racional dos recursos naturais e bem públicos, evitando o desperdício. "Este eixo engloba o uso racional de energia, água e madeira além do consumo de papel, copos plásticos e outros materiais de expediente" (MMA, 2009). Assim, a reutilização de resíduos é uma alternativa para a minimização do consumo de matérias primas e recursos naturais dentro da Instituição a partir do reuso de materiais que antes seriam descartados. 
O papel é o resíduo gerado em maior quantidade pela administração pública, segundo o MMA (2009). Assim, no Campus Trindade, inicialmente, por ser um ambiente escolar e administrativo, pode-se propor a reutilização de papel. Para isso, é necessário disponibilizar um coletor específico para recolher este material. A exemplo de como é realizado no Ministério do Meio Ambiente (2015) e na maioria dos órgãos públicos (MMA, 2009), essa coleta pode ser feita por meio de caixas de papelão pequenas identificadas para o recebimento de papel para reuso como mostra na Figura 15. Sugere-se que essas caixas sejam instaladas em locais estratégicos, como ao lado de impressoras, sala dos professores, salas de aula e biblioteca. O papel será recolhido pela equipe de limpeza e destinado à comissão responsável pelo gerenciamento de resíduos sólidos ou setor designado pela comissão. Esse papel será utilizado para produção de blocos de anotação para servidores e alunos da unidade. Vale destacar que o conteúdo presente nos papéis a serem recolhidos não deva apresentar informações confidenciais. Veja no Quadro 7 orientações para o correto descarte do papel para reuso.

Figura 15 - Método utilizado no Ministério do Meio Ambiente para recolher papel para reuso

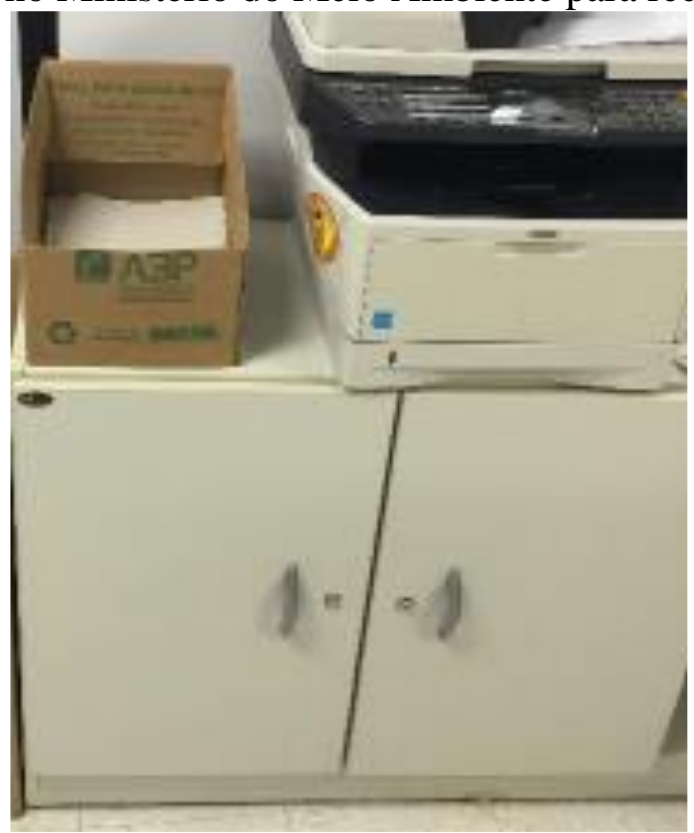

Fonte: MMA (2015). 
Quadro 7 - Procedimentos para descarte do papel para reuso

\begin{tabular}{|l|}
\hline \multicolumn{1}{|c|}{ Para descartar, o papel precisa... } \\
\hline - possuir um dos lados em branco e não utilizado; \\
- não conter grampos, clips e demais materiais, devendo ser retirado, se houver; \\
- não deve estar sujo ou amassado; \\
- não deve ser dobrado; \\
- deve ser descartado com a face branca para cima.
\end{tabular}

Fonte: MMA (2015).

Com o objetivo de otimizar a reutilização e melhorar o aproveitamento de outros materiais, o Ministério do Meio Ambiente criou o Almoxarifado Sustentável. Os principais materiais reaproveitados por esse departamento são: pastas, grampeadores, furadores, porta canetas, canetas, réguas, apontador de mesa e caixa box. Os servidores do almoxarifado são responsáveis por recolher estes materiais que não estão sendo utilizados em determinadas áreas e encaminhá-los para outras que estejam precisando do produto.

\subsubsection{Monitoramento e revisão do Plano}

O monitoramento e revisão do PGRS são componentes importantes a serem realizados pelos responsáveis pelo gerenciamento de resíduos sólidos na Instituição, pois requer uma definição clara dos critérios obrigatórios a serem adotados e um nível elevado de comprometimento dos envolvidos. Isso decorre do fato de que, a partir destas ações é possível identificar os procedimentos exitosos, as melhorias a serem implementadas, bem como os pontos críticos que necessitam ser corrigidos, além de possibilitar replanejar as atividades futuras (MMA, 2009).

Assim, tem-se que o monitoramento da geração de resíduos deve ser contínuo, cíclico e sistematizado. Para isso, são ações essenciais a um monitoramento e avaliação eficientes: (i) 
realização de reuniões periódicas com o objetivo de classificar os objetivos traçados e as ações implantadas no Plano de Trabalho; (ii) Identificação e correção das falhas apresentadas; (iii) Avaliação e reforço dos procedimentos exitosos; (iv) e identificação das ações de controle (MMA, 2009). É recomendável que todo processo de monitoramento seja registrado em documentos e planilhas e que estes sejam arquivados de maneira segura. O objetivo é compor um banco de dados, capaz de disponibilizar informações importantes ao longo do tempo e não restringi-las a um número restrito de funcionários (UEL, 2010). Um modelo de relatório de gerenciamento de resíduos sólidos proposto pelo MMA (2014a) é apresentado no Anexo D.

Nesta etapa se faz importante a elaboração de indicadores. "Um número limitado de indicadores e de fontes de verificação pode substituir uma infinidade de dados e de estatísticas acumuladas nos projetos e, ao mesmo tempo, aumentar a qualidade do acompanhamento" (UFPA, 2008). A partir dos indicadores elaborados pelo MMA, o Quadro 8 propõem ações que poderão ser adotadas para o monitoramento e avaliação do PGRS do Campus Trindade. Recomenda-se também que, inicialmente, as atividades do plano sejam avaliadas e revistas anualmente, podendo este prazo ser revisado de acordo com a realidade apresentada, sendo importante também a realização de avaliações periódicas que garantam o correto funcionamento das ações.

Quadro 8 - Indicadores para monitoramento e avaliação do PGRS do Campus Trindade

\begin{tabular}{|l|l|l|}
\hline \multicolumn{2}{|c|}{ PLANO DE MONITORAMENTO } \\
\hline AÇÃO & INDICADOR & $\begin{array}{l}\text { SETOR } \\
\text { RESPONSÁVEL* }\end{array}$ \\
\hline $\begin{array}{l}\text { Realizar ações de conscientização } \\
\text { (palestras, campanhas, produção de } \\
\text { materiais de comunicação visual) }\end{array}$ & $\begin{array}{l}\text { Indicador de Ações de } \\
\text { Conscientização (IAC) }= \\
\mathrm{N}^{\circ} \text { de ações/ semestre }\end{array}$ & Equipe PGRS e Ascom \\
\hline $\begin{array}{l}\text { Treinar equipe de limpeza em } \\
\text { relação aos procedimentos a serem } \\
\text { adotados com a implantação do } \\
\text { PGRS }\end{array}$ & $\begin{array}{l}\text { Indicador de Treinamento da } \\
\text { Equipe de Limpeza (ITEL) }=\text { n. } \\
\text { treinamentos/semestre }\end{array}$ & Equipe PGRS \\
\hline
\end{tabular}


(Continuação Quadro 8 - Indicadores para monitoramento e avaliação do PGRS do Campus

Trindade)

\begin{tabular}{|c|c|c|c|}
\hline \multicolumn{4}{|c|}{ PLANO DE MONITORAMENTO } \\
\hline \multicolumn{2}{|r|}{ AÇÃO } & INDICADOR & $\begin{array}{c}\text { SETOR } \\
\text { RESPONSÁVEL* }\end{array}$ \\
\hline \multirow[t]{5}{*}{$\begin{array}{l}\text { Coleta } \\
\text { Seletiva }\end{array}$} & Matéria Orgânica & $\begin{array}{l}\text { Quantidade }(\mathrm{kg}) \text { de matéria } \\
\text { orgânica destinada à } \\
\text { compostagem / mês e ano }\end{array}$ & $\begin{array}{l}\text { Equipe PGRS ou } \\
\text { responsável delegado para } \\
\text { tal tarefa }\end{array}$ \\
\hline & Papel & $\begin{array}{l}\text { Quantidade }(\mathrm{kg}) \text { de papel } \\
\text { destinado à reciclagem/ mês e } \\
\text { ano }\end{array}$ & $\begin{array}{l}\text { Equipe PGRS ou } \\
\text { responsável delegado para } \\
\text { tal tarefa }\end{array}$ \\
\hline & Plástico & $\begin{array}{l}\text { Quantidade }(\mathrm{kg}) \text { de plástico } \\
\text { destinado à reciclagem/ mês }\end{array}$ & $\begin{array}{l}\text { Equipe PGRS ou } \\
\text { responsável delegado para } \\
\text { tal tarefa }\end{array}$ \\
\hline & Recicláveis & $\begin{array}{l}\text { Indicador de Resíduo Reciclável } \\
\text { Gerado (IRRG) = quantidade de } \\
\text { recicláveis coletados } \\
(\mathrm{kg}) / \text { entrega para a cooperativa }\end{array}$ & $\begin{array}{l}\text { Equipe PGRS ou } \\
\text { responsável delegado para } \\
\text { tal tarefa }\end{array}$ \\
\hline & $\begin{array}{l}\text { Total recicláveis } \\
\text { destinados às } \\
\text { cooperativas }\end{array}$ & $\begin{array}{l}\text { Quantidade de recicláveis } \\
\text { coletados }(\mathrm{kg}) / \text { entrega para a } \\
\text { cooperativa }\end{array}$ & $\begin{array}{l}\text { Equipe PGRS ou } \\
\text { responsável delegado para } \\
\text { tal tarefa }\end{array}$ \\
\hline \multirow{3}{*}{$\begin{array}{l}\text { Resíduos } \\
\text { Perigosos }\end{array}$} & $\begin{array}{l}\text { Descarte de } \\
\text { lâmpadas } \\
\text { fluorescentes } \\
\end{array}$ & $\begin{array}{l}\text { Quantidade (unidades) de } \\
\text { lâmpadas trocadas/ mês e ano }\end{array}$ & $\begin{array}{l}\text { Equipe PGRS e Setor de } \\
\text { Administração }\end{array}$ \\
\hline & $\begin{array}{c}\text { Descarte de pilhas e } \\
\text { baterias }\end{array}$ & $\begin{array}{l}\text { Quantidade }(\mathrm{kg}) \text { de pilhas e } \\
\text { baterias descartadas/ mês e ano }\end{array}$ & $\begin{array}{l}\text { Equipe PGRS e Setor de } \\
\text { Administração }\end{array}$ \\
\hline & $\begin{array}{l}\text { Logística reversa de } \\
\text { lâmpadas } \\
\text { fluorescentes }\end{array}$ & $\begin{array}{l}\text { Quantidade (unidades) de } \\
\text { lâmpadas recicladas pela } \\
\text { empresa prestadora do serviço / } \\
\text { ano }\end{array}$ & $\begin{array}{l}\text { Equipe PGRS e Setor de } \\
\text { Administração }\end{array}$ \\
\hline \multirow[t]{5}{*}{$\begin{array}{l}\text { Resíduos } \\
\text { Eletrônicos }\end{array}$} & $\begin{array}{l}\text { Descarte de } \\
\text { computadores }\end{array}$ & $\begin{array}{l}\text { Quantidade (unidades) de } \\
\text { computadores inutilizados/ } \\
\text { obsoletos descartados/ mês e ano }\end{array}$ & Setor de Patrimônio \\
\hline & $\begin{array}{l}\text { Descarte de } \\
\text { impressoras }\end{array}$ & $\begin{array}{l}\text { Quantidade (unidades) de } \\
\text { impressoras inutilizadas/ } \\
\text { obsoletas descartadas/ mês e ano }\end{array}$ & Setor de Patrimônio \\
\hline & $\begin{array}{l}\text { Descarte de Tvs } \\
\text { inutilizadas/ } \\
\text { obsoletas }\end{array}$ & $\begin{array}{l}\text { Quantidade (unidades) de TVs } \\
\text { inutilizadas/ obsoletas } \\
\text { descartadas/mês e ano }\end{array}$ & Setor de Patrimônio \\
\hline & $\begin{array}{l}\text { Descarte de } \\
\text { aparelhos telefônicos } \\
\text { inutilizados/ } \\
\text { obsoletos }\end{array}$ & $\begin{array}{l}\text { Quantidade (unidades) de } \\
\text { aparelhos telefônicos } \\
\text { inutilizados/ obsoletos } \\
\text { descartados/ mês e ano }\end{array}$ & Setor de Patrimônio \\
\hline & $\begin{array}{l}\text { Descarte de } \\
\text { aparelhos de fax } \\
\text { inutilizados/obsoleto } \\
\mathrm{s}\end{array}$ & $\begin{array}{l}\text { Quantidade (unidades) de } \\
\text { aparelhos de fax inutilizados/ } \\
\text { obsoletos descartados/ mês e ano }\end{array}$ & Setor de Patrimônio \\
\hline
\end{tabular}


Cabe destacar que estes indicadores podem mudar ao longo da execução do Plano e por isso, também, precisam ser revisados. O MMA, por meio da A3P, disponibiliza alguns modelos de indicadores para serem aplicados em planos de gerenciamento de resíduos sólidos. Um deles é uma cartilha de Indicadores de Desempenho da A3P, onde se encontra índices elaborados a partir dos eixos temáticos do programa, sendo capaz de mensurar as seguintes dimensões: uso racional dos recursos naturais e bens públicos, gestão adequada dos resíduos gerados, contratações sustentáveis, qualidade de vida no trabalho, sensibilização e capacitação.

O outro consiste em um sistema de monitoramento denominado Sistema de Responsabilidade Socioambiental (Ressoa), que possibilita às Instituições acompanhar metas, consolidar informações e fomentar o uso sustentável e racional dos recursos naturais na sua Instituição. O Ressoa foi também desenvolvido a partir dos indicadores de cada eixo temático da A3P. Para acessá-lo é necessário que a Instituição tenha aderido oficialmente ao programa, assumindo o compromisso de enviar o relatório completo, via sistema, anualmente. Tanto o sistema, quanto a cartilha estão disponível na página eletrônica da A3P (http://www.mma.gov.br/responsabilidade-socioambiental/a3p), no menu Monitoramento. 


\section{CONCLUSÃO}

A administração pública tem assumido a responsabilidade de desenvolver estratégias inovadoras que auxiliem no enfrentamento das questões ambientais e promovam uma gestão com foco no desenvolvimento sustentável. Neste sentido, o estudo permitiu analisar o gerenciamento de resíduos sólidos de um Instituto Federal de Educação, Ciência e Tecnologia do estado de Goiás sob duas perspectivas: a legal e a viabilização para a sua implantação na prática.

Inicialmente, partiu-se de uma revisão bibliográfica com o objetivo de se montar um arcabouço teórico e legal capaz de embasar a discussão que permeia a adoção de uma postura sustentável pela administração pública, com foco na busca de soluções para o gerenciamento de resíduos sólidos em órgãos e entidades públicas federais. Conhecer o aparato legal referente direta e indiretamente ao gerenciamento de resíduos sólidos, se faz importante, pois, como o próprio Ministério do Meio Ambiente (2012) preconiza, é a partir do entendimento e aplicação correta da regulamentação que se é possível promover um planejamento e gestão mais eficientes. Esta etapa inicial correspondeu à primeira etapa metodológica aplicada ao projeto: pesquisa bibliográfica, com fins exploratórios.

O PGRS para o Campus Trindade foi elaborado com o objetivo de oferecer ao IF Goiano - Campus Trindade um instrumento que fosse capaz de adequar as ações da Instituição com vistas ao atendimento da legislação ambiental, a capacitação educacional e operacional de funcionários e estudantes no correto manejo dos resíduos gerados. Sua elaboração partiu da identificação do nível de consciência ambiental e de consumo ecologicamente correto da comunidade acadêmica da unidade, a partir da qual foi possível inferir que servidores e alunos do Campus Trindade possuem potenciais traços de consciência ambiental (índice geral de 3,2), mas, em contrapartida, demonstram fracos traços de consumo 
ecologicamente correto (índice geral de 2,4). Dessa forma, pode-se abstrair um cenário favorável à implantação de ações de cunho ambientalmente corretas, pois o público se mostrou receptivo ao tema proposto. A diferença entre os índices indica a necessidade de investimento em ações de conscientização, voltadas, principalmente, para os estudantes.

Conhecer o perfil da população estudada possibilitou oferecer subsídios para um direcionamento mais objetivo e eficiente das ações propostas para a implantação do PGRS na unidade, principalmente no que se refere à estratégias de comunicação direcionadas à conscientização de servidores e alunos. Levando-se em conta apenas o tempo de trabalho declarado pelos servidores na pesquisa identificou-se que o Campus Trindade possui estrutura funcional composta por um quadro de funcionários jovens, em relação ao prazo de aposentadoria, emergindo daí um ambiente favorável para a implementação de uma nova cultura institucional, voltada para as práticas de sustentabilidade. Além disso, por trabalharem no unidade desde o início de seu funcionamento, acredita-se que estes servidores se sintam ainda mais responsáveis pelo funcionamento e manutenção eficientes do campus.

Por meio da composição gravimétrica realizou-se a caracterização quali e quantitativa dos resíduos sólidos gerados no Campus Trindade, identificando a quantidade média de lixo gerada na unidade e sua composição física. Associando esses dados às informações adquiridas através dos questionários, observações in loco, definição do índice de geração per capita e identificação dos graus de consciência ambiental e consumo consciente foi possível definir oito propostas de ações a serem implementadas de forma a iniciar a implantação das atividades de gerenciamento de resíduos sólidos na unidade. A implantação da coleta seletiva será a principal ação a ser implementada na unidade, por estar relacionada diretamente a outras etapas, como campanhas de conscientização e disponibilização de recursos humanos e financeiros, bem como adequação ao decreto 5.940, que prevê a coleta seletiva solidária. 
Por fim, foi prevista a realização de ações de monitoramento e avaliação com objetivo de munir o Grupo Gestor com informações a cerca do funcionamento e manutenção das atividades do Plano. Para mensurar os resultados alcançados e promover a melhora contínua das ações, foram sugeridos também, um conjunto de indicadores, além de ferramentas virtuais disponibilizadas pelo MMA. Os indicadores propostos permitirão a identificação correção de falhas, bem como reconhecimento de procedimentos exitosos, evidenciando os principais pontos a serem abordados durante a revisão.

A intenção geral do PGRS do Campus Trindade é legitimar as ações referentes ao gerenciamento de resíduos sólidos, buscando mostrar que, apesar de ser detectada como a principal, a coleta seletiva não é a única solução ao problema abordado. Dessa forma, ações voltadas para a conscientização e a adoção de princípios de redução e não geração também se fazem importantes na obtenção de resultados positivos. Recomenda-se que o comprometimento da alta gestão para o cumprimento das ações propostas é fundamental para validar o processo de implantação e gerenciamento dos resíduos sólidos na unidade.

Assim, ultrapassar o discurso teórico, consolidando o planejado na prática constitui, hoje, o grande desafio da administração pública brasileira. Nesse sentido, a elaboração deste plano foi motivada pela inquietude da autora em oferecer um instrumento em consonância com as exigências legais e capaz de auxiliar, na prática, o gerenciamento de resíduos sólidos na instituição na qual trabalha. Longe de ser este trabalho um modelo fechado que esgote as discussões referentes ao tema, a pesquisa e o PGRS em questão representam o passo inicial no que diz respeito à institucionalização de ações direcionadas aos resíduos sólidos no Instituto Federal Goiano. 


\section{REFERÊNCIAS}

ABRUCIO, F. L. A reconstrução das funções governamentais no federalismo brasileiro. In: HOFMEISTER, W.; CARNEIRO, J. M. B. (Org.). Federalismo na Alemanha e no Brasil. São Paulo: Fundação Konrd Adenauer, 2001. p. 95-105.

ALMEIDA, J. R. Gestão Ambiental: planejamento, avaliação, implantação, operação e verificação. In: ALMEIDA, J. R.; CAVALCANTI, Y. MELLO, C. S. (Org.). Rio de Janeiro: Thex Ed., 2000.

AMARAL, R. Minimização de Resíduos. In: LEME, S.; MARTINS, G.; BRANDAO, D. (Org.). Guia prático para minimização e gerenciamento de resíduos. São Carlos: USP, 2012. p. 18-21.

ARAÚJO, C. et al. Estudo de caso. Métodos de Investigação em Educação. Universidade do Minho: Instituto de Educação e Psicologia, 2008. Disponível em:

<http://grupo4te.com.sapo.pt/estudo_caso.pdf>. Acesso em: 8 mai. 2015.

ARAÚJO, T. B. de. Brasil nos anos noventa: opções estratégicas e dinâmica regional. Revista Brasileira de Estudos Urbanos e Regionais, Recife, v. 1, n. 2, p. 9-24, nov. 1999.

Desenvolvimento regional: a descentralização valorizaria a diversidade. In:

FLEURY, S. (Org.). Democracia, descentralização e desenvolvimento: Brasil \& Espanha. Rio de Janeiro: Ed. FGV, 2006. p. 373-396.

ARRETCHE, M. T. S. Políticas sociais no Brasil: descentralização em um Estado federativo. Revista brasileira de ciências sociais, São Paulo, v. 14, n. 40, p. 111-141, jun. 1999.

ASSOCIAÇÃO BRASILEIRA DE NORMAS TÉCNICAS. NBR ISO 14001: Sistema de gestão ambiental: especificação e diretrizes para uso. Rio de Janeiro, 1996.

2000.

NBR 9191: especificação: sacos plásticos para acondicionamento. Rio de Janeiro,

NBR 10.004: resíduos sólidos: classificação. Rio de Janeiro, 2004a.

NBR 10.007: Amostragem de resíduos sólidos. Rio de Janeiro, 2004b.

NBR 7500: Símbolos de risco e manuseio para o transporte e armazenamento de material. Rio de Janeiro, 2009.

NBR ISO 26000: Diretrizes sobre responsabilidade social. Rio de Janeiro, 2010. 
BARATA, M. M. L.; KLIGERMAN, D. C.; MINAYO-GOMES, C. A gestão ambiental no setor público: uma questão de relevância social e econômica. Revista Ciência e saúde coletiva, Rio de Janeiro, v. 12, n. 1, jan./mar. 2007. Disponível em: <http://www.scielo.br/scielo.php?script=sci_arttext\&pid=S1413-81232007000100019>. Acesso em: 24 mar. 2015.

BERTOLINI, G. R. F.; POSSAMAI, O. Proposta de instrumento de mensuração do grau de consciência ambiental, do consumo ecológico e dos critérios de compra dos consumidores. Revista de Ciência e Tecnologia, Piracicaba, v. 13, n. 25/26, p. 17-25, mar. 2005.

BIDONE, F. R. Metodologias e técnicas de minimização, reciclagem, e reutilização de resíduos sólidos urbanos. 1. ed. Rio de Janeiro: PROSAB, 1999.

BITTENCOURT, P. T. Metodologia de elaboração do Plano de Gerenciamento de Resíduos Sólidos da UFSC Campus Florianópolis. 2014. 116f. Trabalho de Conclusão de Curso (Graduação em Engenharia Sanitária e Ambiental) - Centro Tecnológico, Universidade Federal de Sana Catarina, Florianópolis, 2015.

BRASIL. Constituição Federal de 1988. Capítulo VI do Meio Ambiente, art. 225. Disponível em:

<http://www.planalto.gov.br/ccivil_03/constituicao/constituicaocompilado.htm >. Acesso em: 13 mar. 2015.

Decreto no 5.940, de 25 de outubro de 2006. Institui a separação dos resíduos recicláveis descartados pelos órgãos e entidades da administração pública federal direta e indireta, na fonte geradora, e a sua destinação às associações e cooperativas dos catadores de materiais recicláveis, e dá outras providências. Disponível em: <http://www.planalto.gov.br/ccivil_03/_Ato2004-2006/2006/Decreto/D5940.htm>. Acesso em: 20 mar. 2015.

Decreto $\mathrm{n}^{\mathbf{0}} \mathbf{7 . 4 0 4}$ de 23 de dezembro de 2010b. Regulamenta a Lei $\mathrm{n} \times 12.305$, de 2 de agosto de 2010, que institui a Política Nacional de Resíduos Sólidos, cria o Comitê Interministerial da Política Nacional de Resíduos Sólidos e o Comitê Orientador para a Implantação dos Sistemas de Logística Reversa, e dá outras providências. Disponível em: <http://www.planalto.gov.br/ccivil_03/_ato2007-2010/2010/Decreto/D7404.htm>. Acesso em: 20 mar. 2015.

Decreto $\mathbf{n}^{\mathbf{0}}$ 7.746, de 5 de junho de 2012. Regulamenta o art. $3^{\circ}$ da Lei $\mathrm{n}^{\circ}$ 8.666, de 21 de junho de 1993, para estabelecer critérios, práticas e diretrizes para a promoção do desenvolvimento nacional sustentável nas contratações realizadas pela administração pública federal, e institui a Comissão Interministerial de Sustentabilidade na Administração Pública CISAP. Disponível em <http://www.planalto.gov.br/ccivil_03/_ato20112014/2012/decreto/d7746.htm>. Acesso em: 20 mar. 2015.

Instrução Normativa no 10, de 12 de novembro de 2012 (a). Estabelece regras para elaboração dos Planos de Gestão de Logística Sustentável de que trata o art. 16, do Decreto ${ }^{\circ}$ 7.746, de 5 de junho de 2012, e dá outras providências. Disponível em: 
http://cpsustentaveis.planejamento.gov.br/wp-content/uploads/ 2012/11/Instru\%C3\%A7\%C3 \%A3o-Normativa-10-2012.pdf>. Acesso em: 20 mar. 2015.

Lei $\mathrm{n}^{\circ}$ 6.938, de 31 de agosto de 1981. Dispõe sobre a Política Nacional do Meio Ambiente, seus fins e mecanismos de formulação e aplicação, e dá outras providências. Disponível em: < http://www.planalto.gov.br/ccivil_03/leis/16938.htm>. Acesso em: 20 mar. 2015.

Lei de Crimes Ambientais n⿳ 9.605, de 12 de fevereiro de 1998. Dispõe sobre as sanções penais e administrativas derivadas de condutas e atividades lesivas ao meio ambiente, e dá outras providências. Disponível em:

<http://www.planalto.gov.br/ccivil_03/leis/19605.htm>. Acesso em: 20 mar. 2015.

Lei $\mathbf{n}^{0}$ 9.795, de 27 de abril de 1999. Dispõe sobre a educação ambiental, institui a Política Nacional de Educação Ambiental e dá outras providências. Disponível em: <http://www.planalto.gov.br/ccivil_03/leis/19795.htm>. Acesso em: 20 mar. 2015.

Lei $\mathbf{n}^{\circ}$ 11.107, de 6 abril de 2005. Dispõe sobre normas gerais de contratação de consórcios públicos e dá outras providências. Disponível em: <http://www.planalto.gov.br/ccivil_03/_ato2004-2006/2005/lei/111107.htm>. Acesso em: 25 mar. 2015.

Lei $\mathbf{n}^{\mathbf{0}}$ 11.445, de 5 de janeiro de 2007. Estabelece diretrizes nacionais para o saneamento básico; altera as Leis nos 6.766, de 19 de dezembro de 1979, 8.036, de 11 de maio de 1990, 8.666, de 21 de junho de 1993, 8.987, de 13 de fevereiro de 1995; revoga a Lei no6.528, de 11 de maio de 1978; e dá outras providências. Disponível em <http://www.planalto.gov.br/ccivil_03/_ato2007-2010/2007/lei/111445.htm>. Acesso em: 20 mar. 2015.

Lei $\mathrm{n}^{\circ}$ 11.795, de 8 de outubro de 2008. Dispõe sobre o Sistema de Consórcio. Disponível em: <http://www.planalto.gov.br/ccivil_03/_ato2007-2010/2008/lei/111795.htm>. Acesso em: 27 mar. 2015.

Lei $\mathbf{n}^{\circ}$ 11.892, de 29 de dezembro de 2008. Institui a Rede Federal de Educação Profissional, Científica e Tecnológica, cria os Institutos Federais de Educação, Ciência e Tecnologia, e dá outras providências. Disponível em: <http://www.planalto.gov.br/ccivil_03/_ato2007-2010/2008/lei/l11892.htm>. Acesso em: 7 abr. 2015.

Lei $\mathbf{n}^{0}$ 12.305, de 2 de agosto de 2010a. Institui a Política Nacional de Resíduos Sólidos; altera a Lei $\mathrm{n}^{\circ}$ 9.605, de 12 de fevereiro de 1998; e dá outras providências. Disponível em: <http://www.planalto.gov.br/ccivil_03/_ato2007-2010/2010/lei/112305.htm>. Acesso em: 20 mar. 2015. 
CABESTRÉ, S. A.; GRAZIADEI, T. M.; POLESEL FILHO, P. Comunicação Estratégica, Sustentabilidade e Responsabilidade socioambiental: um estudo destacando os aspectos teórico-conceituais e práticos.2008. Trabalho apresentado ao XXXI Congresso Brasileiro de Ciências da Comunicação, Natal, 2008.

CARVALHO, J. L. V.; JESUS, S. C.; PORTELLA, R. B. Composição gravimétrica dos resíduos sólidos domiciliares e comerciais do centro da cidade de Barreiras - Bahia. Chão urbano. Disponível em: <http://www.chaourbano.com.br/visualizarArtigo.php?id=65> . Acesso em: 10 mai. 2015.

COLLOVINI. G. T. et al. Implantação de Plano de Gerenciamento de Resíduos em laboratórios de ensino em Química na UFSM. Abes, 2104. Disponível em: <http://www.abes-df.org.br/upload/estudo/2014_10_01/i-062.pdf>. Acesso em: 3 fev. 2015.

CUNHA, R. E. da. Federalismo e relações intergovernamentais: os consórcios públicos como instrumento de cooperação federativa. Revista do Serviço Público, Brasília, n. 3, p. 5-36, 2004.

CURITIBA. Secretaria Municipal do Meio Ambiente. Termo de referência para a elaboração de planos de gerenciamento de resíduos sólidos. Curitiba. 2011. Disponível em: <http://multimidia.curitiba.pr.gov.br/2011/00097518.pdf>. Acesso em: 4 fev. 2015.

DENHARDT, R. B. Teorias da Administração Pública. Trad. de Francisco G. Heidmann. São Paulo: Cengage Learning, 2012.

DOMINGUEZ, S. V. O valor percebido como elemento estratégico para obter a lealdade dos clientes. Caderno de Pesquisas em Administração, São Paulo, v. 7, n. 4, p. 53-64, 2000. Disponível em: <http://www.regeusp.com.br/arquivos/v07-4art05.pdf>. Acesso em: 7 mai. 2015.

FARIA, B. de A; OLIVEIRA, S. M. de; SANTOS, A. de P. Tratamento de resíduos de aulas práticas de Química. Enciclopédia Biosfera: Centro Científico Conhecer, Goiânia, v. 6, n. 10, p. 1-7. 2010. Disponível em:

<http://www.conhecer.org.br/enciclop/2010b/tratamento.pdf>. Acesso em: 21 out. 2015.

GIL, A. C. Como elaborar projetos de pesquisa. 4. ed. São Paulo: Atlas, 2008.

GOMES, P. C. G. Plano de Gestão de Resíduos Sólidos do Campus Gávea da PUC-Rio: elaboração, implementação e diagnóstico de operação. 2012. Dissertação (Mestrado em Engenharia Urbana e Ambiental) - Departamento de Engenharia Civil, Pontifícia Universidade Católica do Rio de Janeiro, Rio de Janeiro, 2012.

GONÇALVES, M. S. et al. Gerenciamento de resíduos sólidos na Universidade Tecnológica Federal do Paraná Campus Francisco Beltrão. Revista Brasileira de Ciências Ambientais, São Paulo, n. 15, p. 79-84, 2010. 
HESPANHOL, I. Água e Saneamento Básico - Uma visão realista. In: REBOUÇAS, A. C.; BRAGA, B.; TUNDISI, J. G. (Org.). Águas Doces no Brasil. São Paulo: Ed. Escrituras, 1999. p. 249-304.

\section{IBAMA - INSTITUTO BRASILEIRO DE MEIO AMBIENTE E DOS RECURSOS}

NATURAIS RENOVÁVEIS. Cadernos de formação. Volume 1: Política Nacional de Meio Ambiente. Volume 2: Como estruturar o sistema municipal de meio ambiente. Volume 3: Planejando a intervenção ambiental no município. Volume 4: Instrumentos da gestão ambiental municipal. Volume 5: Recursos para a gestão ambiental municipal. Brasília: Ministério do Meio Ambiente, 2006.

INSTITUTO ETHOS. Política Nacional de Resíduos Sólidos: desafios e oportunidades para as empresas. Ethos, 2012. Disponível em: <http://www3.ethos.org.br/wpcontent/uploads/2012/08/Publica\%C3\%A7\%C3\%A3o-Residuos-Solidos_Desafios-eOportunidades_Web_30Ago12.pdf>. Acesso em: 24 mar. 2015.

JULIATTO, D. L.; CALVO, M. J.; CARDOSO, T. E. Gestão integrada de resíduos sólidos para Instituições Públicas de Ensino Superior. Revista Gestão Universitária na América Latina (Gual), Florianópolis, v. 4, n. 3, p. 170-193, set./dez. 2011.

LIMA, A. K. T. Principais pontos da Política Nacional de Resíduos Sólidos para a Gestão de Resíduos Municipais. In: EL-DIOR, S. G. (Org.). Resíduos Sólidos: perspectivas e desafios para a gestão integrada. Recife: EDUFRPE, 2014. p. 20-29.

LOPES, A. A. Estudo da Gestão e do Gerenciamento Integrado dos Resíduos Sólidos Urbanos no município de São Carlos (SP). 2003. Dissertação (Mestrado em Ciências da Engenharia Ambiental) - Escola de Engenharia de São Carlos, Universidade de São Paulo, São Carlos, 2003.

MACHADO, C. J. S. Mudanças conceituais na Administração Pública do Meio Ambiente. Ciência e Cultura, São Paulo, v. 55, n. 4, p. 24-26, oct./dez. 2003.

MINISTÉRIO DO MEIO AMBIENTE. Agenda ambiental na administração pública. Cartilha. Brasília, 2009. 96 p.

Guia para elaboração dos Planos de Gestão de Resíduos Sólidos. Ministério do Meio Ambiente, 2011. Disponível em:

<http://www.mma.gov.br/estruturas/srhu_urbano/_arquivos/guia_elaborao_plano_de_gesto_d e_resduos_rev_29nov11_125.pdf>. Acesso em: 3 fev. 2015.

Planos de Gestão de Resíduos Sólidos: Manual de Orientações. Cata Ação, 2012. Disponível em: <http://www.cataacao.org.br/wpcontent/uploads/2012/05/Manual_PERS_PGIRS_2012.pdf>. Acesso em: 12 jan. 2015. 
Como implantar a A3P. Cartilha. 3. ed. Brasília, 2014b. 36p.

Plano de Gerenciamento de Resíduos Sólidos: Instrumento de Responsabilidade Socioambiental na Administração Pública. Compras Governamentais, 2014a. Disponível em: <http://www.comprasgovernamentais.gov.br/arquivos/cartilhas/cartilha_pgrs_mma.pdf/view> . Acesso em: 3 fev. 2015.

. Parceiros com adesão à Rede A3P. Brasília: Ministério do Meio Ambiente, 2014c. Disponível em: <http://www.mma.gov.br/responsabilidadesocioambiental/a3p/parceiros/item/10326>. Acesso em: 20 mai. 2015.

\section{Plano de Gerenciamento de Resíduos Sólidos do Ministério do Meio Ambiente.}

Brasília, 2015. 82 p.

Resolução CONAMA 275/2001. Estabelece o código de cores para os diferentes tipos de resíduos, a ser adotado na identificação de coletores e transportadores, bem como nas campanhas informativas para a coleta seletiva. Disponível em:

<http://www.mma.gov.br/port/conama/legislacao/CONAMA_RES_CONS_2001_275.pdf>. Acesso em: 2 mar. 2016.

MONTAGNA, A. et al. Plano Municipal de Gestão Integrada de Resíduos Sólidos: planejamento e gestão. Florianópolis, 2012. (Apostila).

PENELUC, M. C.; SILVA, S. A. H. Educação ambiental aplicada à gestão de resíduos sólidos: análise física e das representações sociais. Revista Faced, Salvador, n. 14, p. 135165, jul./dez. 2008.

PROSAB - Programa de Pesquisa em Saneamento Básico. Resíduos Sólidos Urbanos: Aterro Sustentável para Municípios de Pequeno Porte. Rio de Janeiro: Associação Brasileira de Engenharia Sanitária e Ambiental, 2003.

QUINTAS, J. S. Educação no Processo de Gestão Ambiental: uma proposta de educação ambiental transformadora e emancipatória. São Paulo: Ambiente, 2011. Disponível em: <http://www.ambiente.sp.gov.br/cea/files/2011/12/Jose_S_Quintas.pdf>. Acesso em: 17 abr. 2015 .

SILVA JUNIOR, S. D.; COSTA, F. J. Mensuração e escalas de verificação: uma análise comparativa das Escalas de Likert e Phrase Completion. Revista Brasileira de Pesquisas de Marketing, Opinião e Mídia, São Paulo, v. 15, p. 1-16, 2014. Disponível em: <http://www.revistapmkt.com.br/Portals/9/Volumes/15/1_Mensura\%C3\%A7\%C3\%A3o\%20 e\%20Escalas\%20de\%20Verifica\%C3\%A7\%C3\%A3o\%20uma\%20An\%C3\%A1lise\%20Com parativa $\% 20$ das $\% 20$ Escalas $\% 20 \mathrm{de} \% 20 \mathrm{Likert} \% 20 \mathrm{e} \% 20 \mathrm{Phrase} \% 20 \mathrm{Completion}$. pdf $>$. Acesso em: 10 mai. 2015. 
TAUCHEN, J.; BRANDLI, L. L. A gestão ambiental em instituições de ensino superior: modelo para implantação em campus universitário. Gestão \& Produção, São Carlos, v. 13, n. 3, p. 503-515, 2006.

UNIVERSIDADE DE SÃO PAULO. Política de Resíduos Sólidos da USP. São Paulo: USP, 2013. Disponível em:

<http://www2.iq.usp.br/assistencia/administrativa/arquivos/Documento_Politica_Residuos_U SP_10042013.pdf >. Acesso em: 13 mai. 2015.

\section{UNIVERSIDADE ESTADUAL DE LONDRINA. Plano de Gerenciamento de Resíduos}

Sòlidos. UEL, 2010. Disponível em:

<http://www.uel.br/proplan/Plano_residuos_\%20final.pdf>. Acesso em: 10 mar. 2016.

UNIVERSIDADE FEDERAL DO PARÁ. Plano Geral de Gerenciamento de Resíduos Sólidos da UFPA. Belém: UFPA, 2008. Disponível em:

<http://www.ufpa.br/prefeitura/relatorios/PGRSS.pdf>. Acesso em: 13 mai. 2015

VERGARA, S. C. Projetos e relatórios de pesquisa em administração. 2. ed. São Paulo: Atlas, 1998.

VIERIA, E. Agenda Ambiental na Administração Pública: um estudo aplicado no Instituto Federal Goiano - Campus Rio Verde. 2013. 97f. Dissertação (Mestrado em Desenvolvimento Regional) - Faculdades Alves Faria, Goiânia, 2013.

YIN, R. K. Estudo de casos: Planejamento e métodos. 2. ed. São Paulo: Editora Bookman, 2001. 205p.

ZANTA, V. M.; FERREIRA, C. F. A. Gerenciamento Integrado de Resíduos Sólidos Urbanos. In: CASTILHOS Jr., A. B. (Coord.). Resíduos Sólidos Urbanos: aterro sustentável para municípios de pequeno porte. Rio de Janeiro: ABES, RIMA, 2003. p. 1-16. 


\begin{abstract}
ANEXOS
Anexo A - Questionário 1 - Diagnóstico da situação do manejo de resíduos sólidos

\section{APRESENTAÇÃO}

Este questionário é parte integrante da pesquisa de mestrado, intitulada "PLANO DE GERENCIAMENTO DE RESÍDUOS SÓLIDOS PARA UMA INSTITUIÇÃO FEDERAL DE EDUCAÇÃO, CIÊNCIA E TECNOLOGIA DO ESTADO DE GOIÁS”, referente ao Programa de PósGraduação strito sensu, mestrado profissional em Gestão Pública (PPGP) pela Faculdade de Planaltina (FUP) da Universidade de Brasília (UnB).

Contato: Juliana Teixeira dos Anjos (Juliana.dosanjos@ifgoiano.edu.br)

\section{CRITÉRIO DE INCLUSÃO}

Este instrumento de pesquisa será aplicado exclusivamente no Campus Trindade e Reitoria do Instituto Federal Goiano (IF Goiano)

Reitoria: Reitor, Pró-reitoria de Desenvolvimento Institucional (Prodi), Pró-reitoria de Administração (Proad), Pró-reitoria de Ensino (Proen), Pró-reitoria de Pesquisa, Pós-Graduação e Inovação (Proppi) e Pró-reitoria de Extensão (Proex).

Campus Trindade: Diretor-geral, Diretor de Ensino, Diretor de Administração, Coordenadores de curso, docentes, técnicos administrativos e terceirizados.

\section{TERMO DE CONSENTIMENTO}

É com satisfação e respeito que solicitamos sua participação na pesquisa sobre Gerenciamento de Resíduos Sólidos na Administração Pública. Além de representar os profissionais da Educação, sua participação no preenchimento deste questionário é essencial para o êxito desta pesquisa, que tem como propósito elaborar um plano de gerenciamento de resíduos sólidos para o IF Goiano - Campus Trindade. Caso não queira identificar-se, sinta-se a vontade, as informações fornecidas por você terão sua privacidade garantida pelos pesquisadores responsáveis. Os sujeitos da pesquisa não serão identificados em nenhum momento, mesmo quando os resultados desta pesquisa forem divulgados em qualquer forma.
\end{abstract}

Nome:

\title{
DIMENSÃO DEMOGRÁFICA E FUNCIONAL
}

\begin{tabular}{|c|c|}
\hline Idade: & \\
\hline Gênero: & \\
\hline $\begin{array}{l}\text { ( ) MASCULINO } \\
\text { Lotação: }\end{array}$ & ( ) FEMININO \\
\hline ( ) Campus Trindade & ( ) Reitoria \\
\hline
\end{tabular}

Setor:

Reitoria: ( ) Gabinete （ )Prodi （ )Proad ～( ) Proen ～( ) Proppi （ ) Proen

Campus Trindade:

Cargo/Função:

Número de servidores na equipe (setor):

Tempo de serviço público:

Teve experiência em processo de gestão de resíduos sólidos, em serviço anterior ao IFGoiano?
( ) nenhuma
( ) pouca
( ) moderada
( ) elevada
( ) muito elevada 


\section{DIMENSÃO: SENSIBILIZAÇÃO/GERENCIAMENTO}

1. Existe alguma ação de sensibilização/conscientização ambiental no Campus Trindade?
( ) $\mathrm{Sim}$
( ) Não

Tipo:

2. Existe grupo gestor responsável pela gestão de resíduos sólidos no IF Goiano ?
( ) $\mathrm{Sim}$
( ) Não

Descreva:

3. Existe grupos gestor responsável pela gestão de responsável pela gestão de resíduos sólidos no Campus Trindade?
( ) $\mathrm{Sim}$
( ) Não
Descreva:

4. O Instituto Federal Goiano destina recursos específicos para a gestão de resíduos sólidos na instituição?
( ) $\mathrm{Sim}$
( ) Não

5. O Campus Trindade destina recursos específicos para a gestão de resíduos sólidos na unidade?
( ) $\mathrm{Sim}$
( ) Não

\section{DIMENSÃO: MANEJO DO RESÍDUO SÓLIDO}

\section{Geração}

6. É conhecido algum índice de geração de resíduo per capita do IF Goiano?
( ) $\mathrm{Sim}$
( ) Não

7. E do Campus Trindade?
( ) $\mathrm{Sim}$
( ) Não

8. Existe varrição, capina, limpeza de bueiros, outro tipo de limpeza do campus?
( ) Sim
( ) Não
Qual tipo?

Quem faz?

\section{Coleta}

9. Existe coleta de entulhos e bens móveis inservíveis?
( ) Sim
( ) Não
Quantidade coletada:

10. Existe coleta seletiva no Campus Trindade?
( ) $\mathrm{Sim}$
( ) Não

Se sim:

Qual a área de abrangência:

Qual tipo de material é selecionado:
( ) Papel
( ) Plástico
( )Informática
( ) Livro
( ) Outros

11. Houve campanha de esclarecimento / conscientização sobre a coleta seletiva?
( ) $\mathrm{Sim}$
( ) Não

12. Existe a presença de catadores, cooperativas ou associações dentro do Campus Trindade?
( ) Sim
( ) Não 
13. Existe estação de transferência?
( ) $\mathrm{Sim}$
( ) Não
Qual a quantidade transferida?

\section{Acondicionamento}

14. O acondicionamento dos resíduos sólidos coletados é realizado de maneira adequada respeitando as instruções normativas da área?
( ) Sim
( ) Não

15. No caso de resíduos gerados nos laboratórios há geração de resíduos pergisos?
( ) $\mathrm{Sim}$
( ) Não

Se sim, como é realizado o recolhimento?

16. Há identificação de resíduos infectantes no acondicionamento segundo norma NBR 7500?
( ) Sim
( ) Não

\section{Transporte Interno}

17. Existe rotina instalada no transporte interno dos resíduos sólidos dentro do Campus Trindade?
( ) Sim
( ) Não
Se sim:
Horário:

18. É adotado recipiente adequado para o transporte interno?
( ) $\mathrm{Sim}$
( ) Não

\section{Armazenamento interno}

19. Existe local destinado ao armazenamento temporário?
( ) $\mathrm{Sim}$
( ) Não
Descrição do local:

20. Material utilizado na construção do local está em conformidade com a norma NBR 12235 ?
( ) $\operatorname{Sim}$
( ) Não

\section{Tratamento}

21. Existe tratamento dos resíduos sólidos coletados?
( ) $\operatorname{Sim}$
( ) Não
Se sim, qual o tratamento?

22. Como é feito o controle da quantidade de lixo a ser destinado?

23. Existe algum pré-tratamento no sentido de eliminar contaminantes microbianos ou anular produtos químicos?
( ) $\operatorname{Sim}$
( ) Não
Armazenamento, Coleta e Transporte Externos

24. O armazenamento externo é realizado em contêineres adequados?
( ) $\mathrm{Sim}$
( ) Não

25. Existe serviço de coleta externo?
( ) $\mathrm{Sim}$
( ) Não 


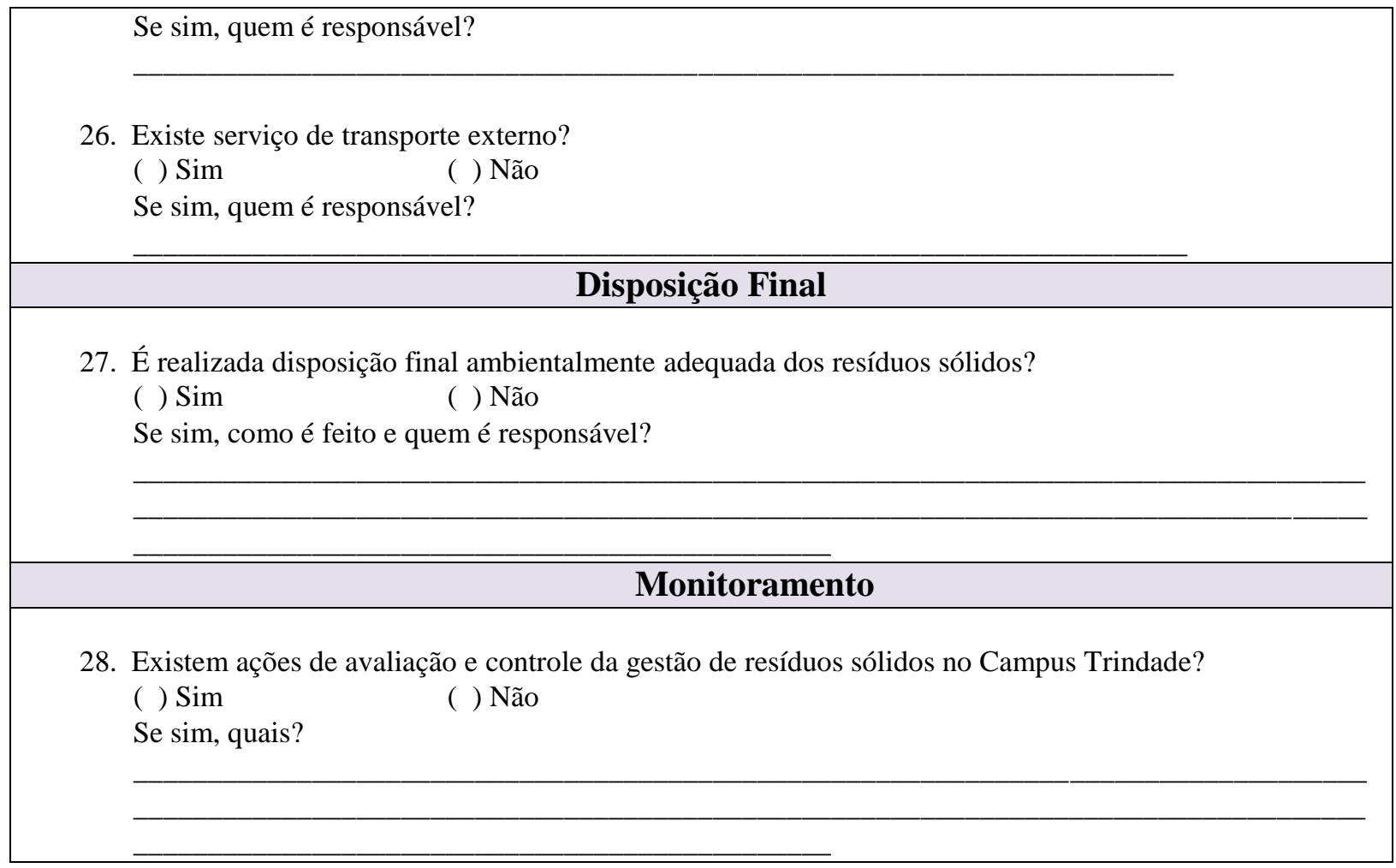




\section{Anexo B - Questionário 2 - Grau de consciência ambiental e de consumo ecologicamente correto}

1. Quando você vai comprar um produto, quais as características que você valoriza e que definem qual produto comprar? Coloque na coluna da direita a ponderação da importância, distribuindo 10 pontos entre as características.

\begin{tabular}{|l|l|l|}
\hline \multicolumn{2}{|c|}{ CARACTERISTICAS } & PONTOS \\
\hline 1 & & \\
\hline 2 & & \\
\hline 3 & & \\
\hline 4 & & \\
\hline 5 & & \\
\hline 6 & & \\
\hline 7 & & \\
\hline 8 & & \\
\hline 9 & & \\
\hline 10 & & \\
\hline
\end{tabular}

2. Antes de jogar algo no lixo, você pensa em como poderia reutilizá-lo?
( )
( )
()

a) Todas as vezesb) algumas vezes c) pouquíssimas vezes $\quad$ d) nunca

3. Você separa o lixo que pode ser reciclado, como papel, plástico, alumínio, vidro ou metais ferrosos?
( )
( )
( )
$($ )

a) Todas as vezesb) algumas vezes c) pouquíssimas vezes d) nunca

4. Evita a queima de lixo doméstico (plásticos, isopor, restos orgânicos)?
( )
( )
( )
d) nunca
a) Todas as vezesb) algumas vezes c) pouquíssimas vezes

5. Procura não deixar a torneira aberta ao escovar os dentes ou fazer a barba?
( )
( )
( )
d) nunca
a) Todas as vezesb) algumas vezes c) pouquíssimas vezes

6. Apaga as luzes e a TV quando sai do ambiente?
( )
( )

( )

d) nunca

a) Todas as vezesb) algumas vezes c) pouquíssimas vezes

7. Utiliza máquinas de lavar roupas ou louças apenas quando estiverem com capacidade máxima preenchida?
( )
( )
( )
$($ )

a) Todas as vezesb) algumas vezes c) pouquíssimas vezes

d) nunca

8. Você se preocupa em não jogar lixo na rua?
( )
( )

( )

a) Todas as vezesb) algumas vezes c) pouquíssimas vezes

d) nunca

9. Você utiliza os dois lados dos papéis, ou reutiliza rascunhos?
( )
( )
( )
a) Todas as vezesb) algumas vezes c) pouquíssimas vezes
d) nunca

10. Ao comprar, você tem a prática de procurar saber se o fabricante tem ações ambientais (leva em conta a postura ambiental do fabricante antes de comprar?)

(

( )

( )

d) nunca

a) Todas as vezesb) algumas vezes c) pouquíssimas vezes

( )

11. Tem a prática de comprar produtos e embalagens fabricados com material reciclado ou 


\section{que podem ser recicláveis?}
( )
( )

a) Todas as vezesb) algumas vezes c) pouquíssimas vezes
( )

d) nunca

12. Antes da compra, você tem a prática de verificar rótulos e embalagens para identificar um produto ambientalmente correto?
( )
( )
( )

d) nunca

a) Todas as vezesb) algumas vezes c) pouquíssimas vezes

13. Você tem a prática de comprar produtos orgânicos?
( )
( )
( )

a) Todas as vezesb) algumas vezes c) pouquíssimas vezes

d) nunca

14. Você tem a prática de comprar produtos de limpeza biodegradáveis?
( )
( )
( )
d) nunca
a) Todas as vezesb) algumas vezes c) pouquíssimas vezes

15. Você tem a prática de comprar lâmpadas e eletrodomésticos que gastam menos energia?
( )
( )
( )
( )

a) Todas as vezesb) algumas vezes c) pouquíssimas vezes

d) nunca

16. Você tem a prática de pagar mais por um produto que não polui o meio ambiente?
( )
( )
( )

a) Todas as vezesb) algumas vezes c) pouquíssimas vezes $\quad$ d) nunca

17. Nas compras, ao encontrar um produto com rótulo que informa que ele foi fabricado de maneira ambientalmente correta, você fica motivado em comprá-lo?
( )
( )
( )

a) Todas as vezesb) algumas vezes c) pouquíssimas vezes $\quad$ d) nunca

18. Que nível de escolaridade você possui?
( )
( )

a) Fundamental

b) Médio

c) Superior

\section{Qual é a sua renda familiar?}

\section{( ) \\ ( )}

a) até um salário min. b) mais de um a cinco salários mínimos
( )

d) Pós-Graduação (especialização)

$$
\text { ( ) }
$$

c) mais de cinco a dez salários mínimos e) Pós-Graduação (Ms / Dr) d) mais de dez a 15 salários mínimos

( )

e) mais de 15 salários mínimos

20. Qual a sua idade?
( )
( )
( )
( )
Até 24 a nos
de 25 a 34 anos
de 35 a 49 anos
acima de 50 anos

21. Sexo: masculino ( ) feminino ( ) 
Anexo C - Lista de Cooperativas de Catadores de Materiais Recicláveis de Goiânia PREFEITURA DE GOIÂNIA

\begin{tabular}{|c|c|c|c|c|}
\hline Ordem & Cooperativas & Presidente & Telefone & Endereço \\
\hline 01 & $\begin{array}{l}\text { Cooperativa dos Catadores de } \\
\text { Materiais Recicláveis "Meio } \\
\text { Ambiente Saudável" } \\
\text { COOPER MAS }\end{array}$ & $\begin{array}{l}\text { Maria de Lurdes } \\
\text { M. Soares }\end{array}$ & $\begin{array}{l}(62) 9978-5362 / \\
(62) 3576-0503\end{array}$ & $\begin{array}{l}\text { Av. Senador Canedo } \\
\text { № } 31 \text { Setor Conj. } \\
\text { Vera Cruz I }\end{array}$ \\
\hline 02 & $\begin{array}{l}\text { Cooperativa de Selecionadoresde } \\
\text { Materiais Recicláveis " Família Feliz - } \\
\text { COOPER FAMI }\end{array}$ & Valdo Alves de Souza & (62) 9259-1835 & $\begin{array}{l}\text { Endereço: Galpão - } \\
\text { Chácara Maringá , n. } \\
\text { 92, km 04, Rodovia } \\
\text { G0-060. }\end{array}$ \\
\hline 03 & $\begin{array}{l}\text { Grupo de Catadores de } \\
\text { MateriaisRecicláveis } \\
\text { FÊNIX CARROSSEL }\end{array}$ & $\begin{array}{l}\text { Lorena Zemir Pereira } \\
\text { de Souza }\end{array}$ & 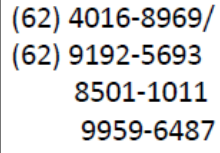 & $\begin{array}{l}\text { Endereço: Belém Qd. } \\
119 \text { Lt. } 775 \text { A } \\
\text { SetorJd. Petrópolis }\end{array}$ \\
\hline 04 & $\begin{array}{l}\text { Cooperativa de Coletores de Material } \\
\text { Reciclável } \\
\text { NOSSA SENHORA AUXILIADORA }\end{array}$ & $\begin{array}{l}\text { Domingos Francisco } \\
\text { da Rocha }\end{array}$ & $\begin{array}{r}62) 8579-0026 \\
9411-2265\end{array}$ & $\begin{array}{l}\text { Rua Trindade Qd. } 01 \\
\text { Lt. 29Residencial São } \\
\text { Bernardo }\end{array}$ \\
\hline 05 & $\begin{array}{l}\text { Cooperativa dos Coletores de } \\
\text { Material Reciclável A AMBIENTAL }\end{array}$ & $\begin{array}{l}\text { Mileny Lima dos } \\
\text { Santos }\end{array}$ & $\begin{array}{l}(62) \text { 9984-1337/ } \\
(62) 8318-2152\end{array}$ & $\begin{array}{l}\text { Rua } 03 \text { Qd. D Lt. } \\
\text { 12Chácara do Retiro }\end{array}$ \\
\hline
\end{tabular}

\begin{tabular}{|c|c|c|c|c|}
\hline 06 & $\begin{array}{l}\text { Grupo de Catadores } \\
\text { NOVA ESPERANÇA }\end{array}$ & Dayane Gonçalves & (62) 8629-2814 & $\begin{array}{l}\text { Rua Jacarandá Qd. } 16 \\
\text { Lt. } 03 \text { Setor } \\
\text { Jardim Botânico }\end{array}$ \\
\hline 07 & $\begin{array}{l}\text { Cooperativa dos Coletores de } \\
\text { Material Reciclável } \\
\text { BEIJA FLOR }\end{array}$ & Claubi Teixeira Lemos & $\begin{array}{l}(62) 8456-3222 / \\
9223-9680\end{array}$ & $\begin{array}{l}\text { Endereço: Rua João } \\
\text { Luiz de Almeida, Qd. } \\
\text { 05, Lts. } 11 \text { e } 12 \\
\text { Setor Criméia Oeste. }\end{array}$ \\
\hline 08 & $\begin{array}{l}\text { Grupo de Catadores de Catadores de } \\
\text { Material Reciclável } \\
\text { COCA MARE }\end{array}$ & $\begin{array}{l}\text { Maria Conceição } \\
\text { F. Silva }\end{array}$ & $\begin{array}{r}\text { (62) } 9395-6229 \\
9913-0375\end{array}$ & $\begin{array}{l}\text { Rua } 03 \text { Qd. D Setor } \\
\text { Chácara do Retiro }\end{array}$ \\
\hline 09 & $\begin{array}{l}\text { Cooperativa dos Catadores de } \\
\text { Material Reciclável "Reciclamos e } \\
\text { Amamos o Meio Ambiente" } \\
\text { COOPER RAMA }\end{array}$ & Dulce Helena do Vale & $\begin{array}{l}\text { (62) } 9643-8895 / \\
(62) 3298-7040 / \\
(62) 9268-7200 / \\
(62) 9291-2244\end{array}$ & $\begin{array}{l}\text { Rua } 55 \text { Qd. } 126 \text { Lt. } 10 \\
\text { Jd. Curitiba III }\end{array}$ \\
\hline 10 & $\begin{array}{l}\text { Grupo de Catadores de Materiais } \\
\text { Recicláveis } \\
\text { CARRINHO DE OURO }\end{array}$ & Décio José dos Santos & $\begin{array}{l}62 \text { ) } 9442-0956 / \\
(62) 9272-5153\end{array}$ & $\begin{array}{l}\text { Rua } 02 \text { Qd. } 08 \text { Lt. } 07 \\
\text { Setor Jardim } \\
\text { Fortaleza }\end{array}$ \\
\hline
\end{tabular}




\begin{tabular}{|c|c|c|c|c|}
\hline Ordem & Cooperativas & Presidente & Telefone & Endereço \\
\hline 01 & $\begin{array}{l}\text { Cooperativa dos Catadores de } \\
\text { Materiais Recicláveis "Meio } \\
\text { Ambiente Saudável" } \\
\text { COOPER MAS }\end{array}$ & $\begin{array}{l}\text { Maria de Lurdes } \\
\text { M. Soares }\end{array}$ & $\begin{array}{l}(62) 9978-5362 / \\
(62) 3576-0503\end{array}$ & $\begin{array}{l}\text { Av. Senador Canedo } \\
\text { № } 31 \text { Setor Conj. } \\
\text { Vera Cruz I }\end{array}$ \\
\hline 02 & $\begin{array}{l}\text { Cooperativa de Selecionadoresde } \\
\text { Materiais Recicláveis " Família Feliz - } \\
\text { COOPER FAMI }\end{array}$ & Valdo Alves de Souza & (62) 9259-1835 & $\begin{array}{l}\text { Endereço: Galpão - } \\
\text { Chácara Maringá , n. } \\
\text { 92, km 04, Rodovia } \\
\text { GO-060. }\end{array}$ \\
\hline 03 & $\begin{array}{l}\text { Grupo de Catadores de } \\
\text { MateriaisRecicláveis } \\
\text { FÊNIX CARROSSEL }\end{array}$ & $\begin{array}{l}\text { Lorena Zemir Pereira } \\
\text { de Souza }\end{array}$ & $\begin{array}{r}\text { (62) } 4016-8969 / \\
\text { (62) } 9192-5693 \\
8501-1011 \\
9959-6487\end{array}$ & $\begin{array}{l}\text { Endereço: Belém Qd. } \\
119 \text { Lt. } 775 \boldsymbol{A} \\
\text { SetorJd. Petrópolis }\end{array}$ \\
\hline 04 & $\begin{array}{l}\text { Cooperativa de Coletores de Material } \\
\text { Reciclável } \\
\text { NOSSA SENHORA AUXILIADORA }\end{array}$ & $\begin{array}{l}\text { Domingos Francisco } \\
\text { da Rocha }\end{array}$ & $\begin{array}{r}62) 8579-0026 \\
9411-2265\end{array}$ & $\begin{array}{l}\text { Rua Trindade Qd. } 01 \\
\text { Lt. 29Residencial São } \\
\text { Bernardo }\end{array}$ \\
\hline 05 & $\begin{array}{l}\text { Cooperativa dos Coletores de } \\
\text { Material Reciclável A AMBIENTAL }\end{array}$ & $\begin{array}{l}\text { Mileny Lima dos } \\
\text { Santos }\end{array}$ & $\begin{array}{l}\text { (62) } 9984-1337 / \\
(62) 8318-2152\end{array}$ & $\begin{array}{l}\text { Rua } 03 \text { Qd. D Lt. } \\
\text { 12Chácara do Retiro }\end{array}$ \\
\hline
\end{tabular}




\section{Anexo D - Modelo da Agenda Ambiental da Administração Pública (A3P) para Relatório de Gerenciamento de Resíduos Sólidos}

\begin{tabular}{|c|c|}
\hline RELATÓRIO DE GERENCIAMENTO DE \\
RESÍDUOS SÓLIDOS
\end{tabular}

\section{Dados da Instituição}

\begin{tabular}{|l|l|}
\hline \multicolumn{2}{|l|}{ Nome da Instituição: } \\
\hline Endereço: \\
\hline Telefone: & E-mail: \\
\hline $\mathrm{N}^{\circ}$ Servidores: & $\begin{array}{l}\text { Incluir o somatório dos servidores, estagiários e } \\
\text { terceirizados }\end{array}$ \\
\hline Área Construída (m2) & \\
\hline Informar se é prédio próprio ou alugado - \\
\hline Informar se é Edifício Sede - \\
\hline Idade do prédio \\
\hline Observações:
\end{tabular}

2. Dados do relatório e responsável pelo PGRS

\begin{tabular}{|l|l|}
\hline Data de apresentação: & Incluir a data de conclusão do relatório \\
\hline Período de avaliação: & $\begin{array}{l}\text { Incluir o período em que os dados foram coletados / por exemplo: } \\
\text { janeiro a julho/2014 }\end{array}$ \\
\hline Ciclo: & Informar se o monitoramento é semestral ou anual. \\
\hline Nome do Responsável pelo PGRS: \\
\hline Cargo: \\
\hline Telefone: \\
\hline Email: \\
\hline Comissão responsável pela elaboração do PGRS: \\
Listar todos os membros que participam da Comissão na instituição
\end{tabular}




\section{Classificação dos Resíduos Gerados}

\begin{tabular}{|c|c|c|}
\hline \multicolumn{3}{|c|}{ Resíduos Não Perigosos (classe II) } \\
\hline Orgânicos & $\begin{array}{l}\text { Frequência de geração } \\
\text { (mensal, semestral, anual, etc) }\end{array}$ & $\begin{array}{l}\text { Quantidade gerada } \\
\text { (Kg, ton, unidades, etc..) }\end{array}$ \\
\hline \multicolumn{3}{|l|}{ Restos de alimentos } \\
\hline \multicolumn{3}{|l|}{ Galhos e folhas secas } \\
\hline \multicolumn{3}{|l|}{ Observações: } \\
\hline Recicláveis & $\begin{array}{l}\text { Frequência de geração } \\
\text { (mensal, semestral, anual, etc) }\end{array}$ & $\begin{array}{l}\text { Quantidade gerada } \\
\text { (Kg, ton, unidades, etc..) }\end{array}$ \\
\hline \multicolumn{3}{|l|}{ Papel } \\
\hline \multicolumn{3}{|l|}{ Papelão } \\
\hline \multicolumn{3}{|l|}{ Plásticos } \\
\hline \multicolumn{3}{|l|}{ Metais } \\
\hline \multicolumn{3}{|l|}{ Vidros } \\
\hline \multicolumn{3}{|c|}{$\begin{array}{l}\text { Observações: } \\
\text { Informar quantidade e frequência de reutilização de Papel }\end{array}$} \\
\hline Resíduos de obras e reformas & $\begin{array}{l}\text { Frequência de geração } \\
\text { (mensal, semestral, anual, etc) }\end{array}$ & $\begin{array}{l}\text { Quantidade gerada } \\
\text { (Kg, ton, unidades, etc..) }\end{array}$ \\
\hline & & \\
\hline & & \\
\hline & & \\
\hline & & \\
\hline Observações: & & \\
\hline
\end{tabular}

\begin{tabular}{|c|c|c|c|}
\hline \multicolumn{4}{|c|}{ Resíduos Perigosos } \\
\hline \multicolumn{2}{|l|}{ Produtos } & $\begin{array}{l}\text { Frequência de geração } \\
\text { (mensal, semestral, anual, etc) }\end{array}$ & $\begin{array}{l}\text { Quantidade gerada } \\
\text { (Kg, ton, unidades, etc..) }\end{array}$ \\
\hline \multicolumn{4}{|l|}{ Lâmpadas Fluorescentes } \\
\hline \multicolumn{4}{|l|}{ Baterias } \\
\hline \multicolumn{4}{|l|}{ Pilhas } \\
\hline \multicolumn{4}{|l|}{ Pneus } \\
\hline \multicolumn{4}{|l|}{ Eletroeletrônicos } \\
\hline \multicolumn{4}{|c|}{ Embalagens contaminadas com óleos } \\
\hline \multicolumn{4}{|l|}{ Observações: } \\
\hline \multicolumn{4}{|c|}{ Rejeitos } \\
\hline Produtos & $\begin{array}{r}\text { Fre } \\
(\mathrm{me}\end{array}$ & $\begin{array}{l}\text { uência de geração } \\
\text { al, semestral, anual, etc) }\end{array}$ & $\begin{array}{l}\text { Quantidade gerada } \\
\text { (Kg, ton, unidades, etc..) }\end{array}$ \\
\hline $\begin{array}{l}\text { Papel higiênico, palito de } \\
\text { dente, } \\
\text { fi ltro de cigarro, etc. }\end{array}$ & & & \\
\hline
\end{tabular}




\section{Segregação}

Implanta Coleta Seletiva? S/N

Adota Logística Reversa? S/N

Possui plano de destinação de Resíduos Perigosos? S/N

Adota outro processo? Informar

Observações:

\section{Transporte e Armazenagem}

Acondiciona embalagens de acordo com a classe de resíduo gerado? S/N

Os locais de armazenagem são identi_cados e caracterizados? S/N

Sempre observa as normas sobre período máximo de armazenamento? S/N

Informar o responsável pelo transporte dos resíduos:

Observações:

\section{Destinação Final}

Identificação e quantidade do resíduos destinado

\begin{tabular}{|l|l|l|}
\hline Tipo de Resíduo & Quantidade total destinada & Destinação Final \\
\hline Reciclável & & \\
\hline Perigoso & & \\
\hline & & \\
\hline No caso de cooperativa: & \\
Nome da Cooperativa ou associação: & \\
CNPJ: & \\
Endereço: & \\
Contato: & \\
Representante Legal: & \\
Destinação Final: & \\
\hline Observações: & \\
\hline
\end{tabular}

